\author{
${ }^{1}$ 昭和大学医学部外科, ${ }^{2}$ 日本大学医学部第三外科 \\ ${ }^{3}$ 板橋中央総合病院 \\ 加藤貴史, 新井一成, 小池 正, 石井淳一, \\ 村田郁夫, 森 洋幸, 田中 隆, 坂部 孝, \\ 峯尾和宣, 渡㲽哲弥, 中村哲夫,
}

水中スパーク方式による体外衝擊波結石破砕療法（

Extracorporeal Shock Wave Lithotripsy,以下ESWL) は, 最近胆のう結石症に応用されているか，適応, 効 果に関し不明な点も少なくない。今回われわれは E S W L を30例の胆のう結石症患者に施行し, 臨床的検討 を行った。

【対象・方法】症例は，総胆管結石や胆のう炎を合併 するむの, 排泄性胆のう造影法で䏣のうが描出されない あのや胆のう収縮機能を認めないあのを除外し，22歳か ら66歳までの男性20例女性10例を対象とした。結石は 単一結石17例 (直径 $9 \sim 24 \mathrm{~mm}$ ), 複数結石13例(直径 5 〜 $25 \mathrm{~mm})$ であり,石灰化のみられたものは 6 例であった。

治療は, E S W L 施行 1 週間前よりUDC A $300 \mathrm{mg} /$ 旧 C D C A 300 mg/日を経口投与し，西独Dornier 社製胆 石破碎装置を使用して, 硬膜外または静脈麻酔下に 16 , $5 \mathrm{kv}$ で $1800 \sim 2000$ 回の衝撃波発射を行った。E S WL 後, 第 $1,3,5$ 病日に起音波検查, 血液検查を施行 し, 破研状態の判定および臨床経過観察を行った。

【結果】1) E SWL施行中は特に合併症を認めず，安 全に治療することができた。結石が微細な破片に破砕 されたものは21例であった。比較的大きな破片が残存 したものは 9 例で, うち複数結石 7,例, 石灰化のみら れた結石 4 例であり， C T検査では 9 例とも胆石 C $\mathrm{T}$ 値は50H U以上であった。また，E SW Lを 2 回施行 したものは 9 例中 4 例で，うち 2 例は微細片に破砕さ れた。2) E SW L後の合併症は, 腹痛10例, 発熱 4 例 肉眼的血尿 2 例であり, 大部分は一過性のものであっ たか，急性胆のう炎を 1 例, 急性(軽症)膵炎を 1 例に 認めた。急性胆のう炎併発例は, 保存的治療が無効で 手術を施行したとてろ， $7 \mathrm{~mm}$ の破片が胆のう管に嵌頓 しており，胆のう蓄膿症を呈していた。急性膵炎例は E R C P で膵胆管合流異常がみられ，保存的治療で軽 快した。3)臨床検查では，急性胆のう炎および急性膵 炎合併例を除けば, 白血球上昇10例, 血清トランスア ミナーゼ上昇10例, C P K 高值22例, 尿潜血13例を認 めたが，いずれも一過性で数日以内に正常化した。

【考察】1) 胆のう結石で, 数の多いむの, 石灰化を ともなうもの, CT値の高いものは, E SWLで破砕 され難い傾向がある。今後の画像診断等による胆石の 質的検討が重要である。2）破片の消失, 結石の再発 に関して, 経口胆石溶解剂併用による長期の経過観察 が必要である。

\section{体外衝擊波胆石破砕㙩法の基礎的検討 とくに組織障害について}

${ }^{1}$ 日本大学第三外科, ${ }^{2}$ 昭和大学外科,

${ }^{3}$ 板橋中央総合病院,

森 洋幸, 村田郁夫, 田中 隆, 坂部 孝,

加藤貴史, ${ }^{2}$ 小池 正 $^{2}$, 石井淳一,

峯尾和宣, ${ }^{3}$ 渡辺哲弥, ${ }^{3}$ 中村哲夫 ${ }^{3}$,

今日, 胆石症におりる体外衝撃波破砕療法 (以下 $\mathrm{E}$ SWL）が注目されているか，我々は，乙の治療機を 用い胆のう結石症患者35例を経験した。このうち 5 例 は胆摘術施行予定患者で術前に E SWLを施行し, 手 術時に組織障害の程度, 結石の破砕状態を観察した。 今回は, その結果に加え, 雑種成犬を用いた E S W L による組織障害の実験結果を合わせて報告する。

【装置】水中スパーク方式の西独 Dor nier 社製GM1 を使用した。 $16,5 \mathrm{kv} ， 1 \mu$ 秒で放電する電極を用 い, 反射板で外部焦点に衝擊波を集束させるむのであ る。

【方法・結果】 A）手術前の胆石症患者, 男性 3 例 女性 2 例, 計 5 症例に対しESWLを施行した。開腹 時, 肉眼的には胆のうに軽度の装膜下血腫を認めたも の 1 例, 肝表面の限局性の色調変化が 1 例で, 他はほ とんど異常を認めなかった。組織学的には肝被膜下血 腫, 胆のうの巣状出血などを認めた例もあった。

B）雑種成犬10匹を用い肝臓，胆のう壁，肺に焦点を 一致させ肝臓, 胆のうにはそれぞれ 1,800 発, 肺には 1,000 発の衝撃波を発射した。剖検時の肉眼所見とし ては䀒使, 肺ともに $3 \sim 5 \mathrm{~cm}$ 徍の変色部を認め, 時間 の経過した例では肝とその周囲組織との瘉着が著明で あった。胆のうは軽度の将膜下出血が認められた。組 織学的には胸膜下を主体とする出血壊死, 肺胞内出血 肝臓では浆膜下や実質内の出血, 時間が経過した例で は肝実質の壊死、小葉の改築像を認めたものもあった。 胆のうに発射した例では粘膜には大きな変化はなく， 将膜下に広がる出血之壁の肥厚, 浮腫を認めた。

【まとめ】衝撃波による組織障害としては装膜下, 胸 膜下などの組織の境界に著明であることが特徴的であ ると思われる。更に犬の実験では実質障害もみられと くに肝䑏では出血と壊死を認める場合があり臨床例に おける一過性のトランスアミナーゼの上昇を裏付ける 所見と言える。また肺では，その表面において組織障 害の程度が強く, 深部ほどその程度は軽徴であった。 これは, 肺の音響学的インピーダンスによる影響と思 われた。 
278 Microwave Lithotomy 一同軸ケーブ ルの先端出力と胆石破壊力に関する検討一

弘前大学医学部第 2 外科

志田正一, 井上茂章, 遠藤正章, 仲地広美智,

今 充, 小野慶一

肝内・総胆管結石, 特にビリルビンカルシウム結石 に対し，経胆道鏡下非観血的砕石を施行するにあたり， われわれはマイクロ波砕石法を提案し10症例の治療を 経験したが, その過程で以下の諸点を課題として, 過 去の本学会で言及してきた。すなわち(1)同軸ケーブル の伝送損失, 出力不足。(2)浮遊結石。(3)硬性結石。(4) 結石直視不可能部位。以上の5ちでも(1)は大きな課題 であり, 現在までに種々のヶーブルを試作し, 工夫を 続けているので報告する。【装置, 方法】マイク口波 発生装置は肝切除用Microtaze ${ }^{\circledR}$ (平和電子K.K., 日本 光電K.K.) を用い, 同軸ケーブル長は $250 \mathrm{~cm}, 180 \mathrm{~cm}$, $80 \mathrm{~cm}$ とした。先端電極については，初期の針状電極の 他に結石への刺入効果を目差し尖状電極, 結石への接 触面積の增加を期待して球状電極，また誘電効果にと どまらず導電効果をも目差して双極電極を試作検討し， さらに電極先端を約 $1 / 4$ 波長折り曲げ, 電流定在波のピ ークを先端に生ぜしむる様にした折りたたみ電極をも 試作し上記の諸電極と比較した。装置の出力は $40 \mathrm{~W}$ し, 電極出力は固化パラフィンの融解径と, 摘出結石 の破壊効果で検討した。【結果】臨床症例を治療する にあたり, ケーブル長は $80 \mathrm{~cm}$ で充分であった。先端出 力は $250 \mathrm{~cm}, 180 \mathrm{~cm}$ 長のケーブルに比し $80 \mathrm{~cm}$ 長のもので 向上した。尖状電極は針状に比し結石に刺入され易く 破壊効果も良好であった。球状電極では先端出力の向 上をみたが, 尖状や針状電極のような結石中への刺入 状態が得られないため砕石効果には難があった。しか るに双極電極では, 針状電極, 尖状電極に比べて先端 出力と結石表面の損壊力が格段に向上し, それに続く 結石中への刺入も得られ易かった。またてれらの効果 は湿った結石について良好であった。さらに折りたた みアンテナでは双極電極に比し $1 / 3$ の接触時間で同等 の先端出力を得ることが可能であった。

【考察】尖状電極では内視鏡鉗子孔を傷つける怖れ があるため慎重な操作が必要である。また球状電極で は灌流液中へのエネルギー散逸の低減, 針状電極との 併用等が必要と思われた。以上に対し, 双極電極は先 端出力, 結石損壊力に優れ, 今後さらに改良検討する に值する電極と思われ，また折りたたみアンテナの採 用も有用とおもわれた。なお伝導度に関与すると思わ れる結石, 胆汁中の金属濃度ならびに灌流液について の検討をも併せ報告したい。
279 肝内および総胆管結石症の胆道鏡下截石 術一電気水圧衝繋波碎石装置の有用性について一

\section{関西労災病院 外科}

○日田新太郎, 植田俊夫, 大島 進, 北川和則 女川 格, 奥 邦彦, 渡辺一弘, 矢野佳子 <研究の目的>肝内および総胆管結石症の胆道鏡下 截石術における電気水圧衝慗波碎石装置 (以降, 砕石 装置）の有用性を検討すること。

〈研究の対象〉胆道鏡下にバスケット鉗子を用いる截 石術が不能あるいは難渋した肝内結石症 3 例之総胆管 結石症 2 例。〔症例 1 〕 56歳, 男性。胆石, 総胆管結 石, LR型肝内結石症。胆摘術および総胆管切開術後 にTチューブ廣孔を介する術後胆道鏡 (POCS) 下截石 術を施行。〔症例 2 〕 64歳, 男性。上部胆管癌に併発 したL型肝内結石症。減黄の為に設置した経皮経肝胆 道ドレナージルートを介する経皮経肝胆道鏡 (PTCS) 下 截石術を施行。〔症例 3 ] 81歳, 女性。総胆管結石およ ひL型肝内結石症。急性化膿性胆管炎を併発。手術拒 否の為, PTCS下截石術を施行。〔症例 4] 79歳, 男性。 総胆管結石症。高秢のため, PTCS下截石術を施行。 [症例 5 ] 80 歳, 男性。胆摘, 総胆管切開術後の再発総 胆管結石症, 急性化滕性閉塞性胆管炎から敗血症にい たる。心肺機能に問題あるために, PTCS下截石を施行。 〈研究の結果>1）胆道鏡施行回数は症例 1 が 8 回, 症例 2 が 2 回，他は 1 回であった。2）全例で結石を 完全除去できた。3）要治療日数は, 症例 1 が50日, 症例 2 か 43 日, 症例 3 が36日, 症例 4 が24日, 症例 5 が37日であった。4）胆管癌で死亡した症例 2 を除き, 他の 4 例の予後は良好であった。

<研究の考察> 1) 胆道鏡はOLYMPUS CHF TYPE B 3 Rを使用した。鉗子孔に血管造影用シースの三方活 栓付一方弁を装着し, 鉗子や砕石プローベの挿入，破 砕中も半生食水の注入を意のままにし，胆管内腔の良 い視野を確保し得た。2）砕石装置はURAT-1Mを 使用した。粉砕された結石の大きいものはバスケット 銝子で除去し，微小のものは砕石術後留置した $24 \mathrm{Fr}$ のPTCSチューブから自然排石させた。3）治療日数 については, 症例 1 の様な肝内結石症では砕石装置な しの頃に比べ, 短期間であった。症例 $3 ， 4 ， 5$ の様に 手術をすれば， $\mathrm{T}$ チーブ留置を余儀なくされる症例 では, 結果の要治療日数は満足できるむのと考える。 4）PTCS下截石を施行した症例はいずれも胆莫に 対する手術的処置を必要とせず，なおかつ手術の施行 がちゅうちょされる症例を選択した。PTCS掼孔の 掂張方法は, 患者の負担を考虑して, $3 \sim 4$ 日毎の 1 〜 3 Frサイズの拡張を22Frサイズまで施行している。 <研究の結論>電気水王衝撃波砕石装置は肝内結石 や総胆管結石の胆道鏡下截石術に際して有用な装置 である。 
280 肝内・総胆管結石に対する電気水圧衛撃 波砕石法一胆石破壊に関する基礎的検討一

\section{弘前大学医学部第 2 外科}

仲地広美智, 井上茂章, 遠藤正章, 志田正一 今 充, 小野慶一

肝内・総胆管結石症に対し我々はマイク口波砕石法 を発案実施し, 過去の本学会総会で述べてきたが, そ の経験, 成績を参考にしてさらに内視鏡下衛撃波砕石 法（以下本法）も導入し，胆石破壊の機序と本法の改 良，改善点について述べてきた。今回，結石と装置に 関する基礎的検討をさらに進めた結果, 若干の知見が 得られたので報告する。

【装置，材料】装置はLithotron EL-21（W altz 社）を用い，摘出した乾燥ビ石，二石を破壊対象とし た。また郜床症例は肝内結石 18 例, 総胆管結石 7 例を 対象とした。

【方法】Lithotron EL-21の出力条件を放電強度レ ベル I , 放電の周波数 II $(20 \mathrm{~Hz})$ と設定し, 生食水浸 漬下の結石に対し衝撃を与えた。さらに第28回本学会 総会でも述べた如く，圧電素子で放電波形ならびに衝 撃波とされる過渡波形を記録,また周波数分析を $\mathrm{MHz}$ のオーダーの高域まで行った。ついでビリルビンカル シゥム結石標本について微細構造, 特に周期構造の単 位を求め, さらに走查電子顥微鏡で同じく周期構造の 観察を行った。

【結果】ビ石に対する破壊効果は良好であった。硬 い外殼を有するビ石やコ石でも外殼を壊しさえすれば 効果は期待できた。臨床症例全例で破壊は可能であり， ビ石症例は総胆管結石症（混合石）の 2 例よりも破壊 され易かった。䘖撃波とされる過渡波形幅は約 $7.5 \mu$ 秒 で周波数は約 $140 \sim 150 \mathrm{KHz}$ と計算された。周波数分 析結果もほぼ同じく150〜 $200 \mathrm{KHz}$ 領域に分布がみら れ, さらに高いオーダーでは $1 \mathrm{MHz}$ 场に $100 \mathrm{MHz}$ の域に分布がみられた。ビ石の細小周期構造は $1 \mu$, 硬い外殼は $1 \mathrm{~m}$ の単位であり, 電顥的には約 $10 \mu$ を単 位とする結晶層とカルシゥム沈着層との周期構造が主 体を成すとうかがわれた。

【考察】我々や後町らが指摘してきた如く，本装置 の砕石効果が厳密な意味での衝擊波によるものか否か 不明な点が多い。衝撃波効果が顥著であるために必要 とされる音響インピーダンスの急峻な断裂はコ石で明 瞭であり，体外衝撃波装置による効果からも肯ずける。 しかるに本法の効果はビ石で顥著であるため衝撃波以 外の関与も考えられ, その際, 周期構造を考虑して結 石へ破買のための振動エネルギーを与えることにより 良好な効果をあげるととも期待しうる。その際の振動 数は周期構造単位と $\mathrm{D}^{\prime}$ Alembertの関係式から $140 \mathrm{~K} \mathrm{~Hz}$ $1.4 \mathrm{M} \mathrm{Hz}, 140 \mathrm{MHz}$ のオーダーとなり，周波数分析の 結果と略一致する。今後とも検討を続けたい。
281 胆道精査法の意義

胆管結石手術における術中ならびに術後

帝京大学第一外科

内山勝弘, 高田忠敬, 安田秀喜, 長谷川 浩,

土屋繁之, 三須雄二, 斉藤康子, 四方淳一

われわれは，胆管切開切石例に対しては遺残結石予 防の観点から, 術中胆道造影 ( 結石切石困難例では術 中胆道鏡も付加）および術後 3 週後に T千ューブ造影 と胆道鏡検查を行っている。そてで自験例における術 中術後の胆道精查法を遺残結石の問題から検討し, 乙 の検查法における治療的意義の評価を試みた。

【対象および方法】1981年からの 6 年間に胆管切開 切石を行った総胆管結石79例および肝内結石13例を対 象とした。これらのうち, 術中胆道造影と胆道鏡を行 った群は総胆管結石 26 例および肝内結石 5 例の計 31 例 であった。また, 術中胆道造影のみ行った群は総胆管 結石53例および肝内結石 8 例の計61例であった。これ ら 2 つの群における術中胆道精查の所見亡術後遺残結 石の発生の関係について比較検討した。

【成績 】(1術中胆道造影に加え胆道鏡を施行した31 例についてみると，巨大結石であったためと胆管狭窄 のため術中に切石できなかった肝内結石 2 例では結石 故意遺残となった。術中検查にて遺残結石なしと判定 しながらも術後検查にて遺残結石をみたものは 1 例で, てれらはいずれも術後胆道鏡下に完全切石し得た。ま た, 術前に胆管結石が確認されず術中検查にて結石が みられた総胆管結石の 1 例では術中胆道鏡下に切石で きた。他の27例については遺残結石むなく，とくに問 題はなかった。(2)術中に胆道造影のみ施行した61例に ついてみると，緊急手術を行った総胆管結石の 5 例之 肝内結石の 1 例では結石故意遺残となった。術中検查 にて遺残結石なしと判定しながらあ術後倹查にて遺残 結石をみたものは11例で，乙れらはすへて術後胆道鏡 下に切石できた。また，術前に胆管結石を認めず，術 中検查にて胆管結石を発見し切石したものが 4 例あっ た。他の40例については遺残結石むなく問題はなかっ た。(3)結石故意遗残症例を除き, 術後検查にて遺残結 石を認めたものは術中胆道造影+胆道鏡群では $3.6 \%$ であったのに対し, 術中胆道造影のみの群では20\%と 有意 $(\mathrm{p}<0.05)$ 亿術後遗残結石の発生が多かった。

【まとめ】術中胆道精查法として胆道造影に胆道鏡 を行うにあたっては，手技むやや煩雑で時間を要する という難点はあるものの, 胆管結石を切石した症例に 限ってみれば, 胆道造影のみの症例に比へ有意に遺残 結石の発生を低下させることができた。また，遺残結 石例に対しては術後胆道鏡下に全例切石が可能であっ た。このととより，胆管内ならびに肝内に結石がある 症例については, 術中ならびに術後胆道鏡検査をルチ ーン化するととが望ましいと思われる。 
282 経時的変化を中心比

イヌ膵ラ島の分離と培養 $-\mathrm{B}$ 細胞機能の

大阪大学第 1 外科

弓場健義、宮田正彦、中村正廣、伊豆蔵正明、 浜路政靖、坂本嗣郎、田中康博、奥村賢三、 中場寛行、小川法次、道清 勉、北川 透、 岩瀬和裕、中尾量保、川島康生

[目的］ヒト、イヌなど大動物の膵ラ島分離は、小動物 に比し困難である。今回我々はラ島分離をより容易なら しめることを目的として、コラーゲナーゼ膵管灌流法と マジックテープを用いる方法を組み合わせた分離法を試 み、併せて、in vitroでの経時的B細胞機能評価を行っ た。

[万法]雑種成犬より摘出した全脺を Collagenase (Type N、0.1\%) にて膵管灌流 (37C、40分) し、 細切後、マジックテープを用いて振增 $(180 \mathrm{c} / \mathrm{s} 、 15$ 分）した。 $420 \mu \mathrm{m}$ の steel mesh にて滤過し、ラ島を 分離した。Hand pick にてラ島20個を組織培着用マ ルチプレートに移し、10\%牛胎血清を加えたRPM I 1640 にて $5 \% \mathrm{CO}_{2} 、 37 \mathrm{C}$ の条件で培着した。培着液交換 は最初の 2 日間は 1 日毎に、その後は 3 日毎に行った。 また、培養後 $1 、 7 、 14 、 21 、 30$ 日目にグルコース刺敫 試験を行った。すなわち、同一ラ島を50 mg/dl と500 $\mathrm{mg} / \mathrm{dl}$ のグルコース曟度で 2 時間づつ順次刺激した。 インスリン（IRI）測定は、2抗体法にて行った。

[成績] 雑種成犬 8 頭の脺重量は23.3 2 2.6g（Mean 士 SE ) であり、分離ラ島数は $65500 \pm 4300 / 1$ 膵、3040土 420/膵 $\mathrm{g}$ であった。培養液中に放出されたインスリン 量は、培養 1 日目 $1210 \pm 196 \mu \mathrm{u} / 10$ islets/日 (Mean $\pm \mathrm{SE} 、 \mathrm{n}=8$ ） と最高值を示し、2〜 7日目は321 \pm 37 $114 \pm 14 \mu \mathrm{u} / 10$ islets/日、8〜20日目は 18.9土4.5〜 $4.9 \pm 1.0 \mu \mathrm{u} / 10$ islets/日、 $21 \sim 30$ 日目は2.8土1.1〜 $1.1 \pm 0.2 \mu \mathrm{u} / 10$ islets/日と漸減した。一方、培養30 日以降に培養液が真菌等により污染した際のインスリン 放出量は87.7 $\pm 23.7 \mu \mathrm{u} / 10$ islets/日 $(\mathrm{n}=8)$ で前日 に比し36.3土22.3倍であった。グルュース刺激試験にお いて $50 \mathrm{mg} / \mathrm{dl}$ 負荷時のインスリン放出量を100とした 時の $500 \mathrm{mg} / \mathrm{dl}$ 負荷時のインスリン放出量をみると、 培養 1 日目 $223 \pm 10.0($ Mean $\pm S E 、 n=6) 、 1$ 週目 $140 \pm 26.0(n=2) 、 2$ 週目212.3土26.0 ( $n=4) 、 3$ 週 目403 $(n=1) 、 4$ 週目85.0土15.3 $(n=3)$ であり、 1 日目と 2 週目で有意の増加 $(\mathrm{p}<0.05)$ を示した。

[結論]グルコース刺激試験において3週目までは良好 なインスリン反応性を保持したが，4週目以降において はインスリン反応性は低下するものと考学られた。長期 培養においてはインスリン放出量は徐々に低下していく ものと考えられた。しかし、感染時のインスリン放出量 の増加より考えてラ島のインスリン産生能は残されてい ることが示唆された。
283 イヌ膵切除後におりる残存膵外分泌機能 の経時的観察一意識下脂肪酸十二指腸内負荷による検 討-

\section{京都大学第 1 外科}

小切匡史、井上一知、土井隆一郎、角昭一郎

細谷 亮、尹 光俊、戸部隆吉

膵切除後の残存膵外分泌機能の経時的変化を解明す る上で、意識下の膵外分泌変動を直接観察することの 意義は大きいと考えられる。我々は現在まで、種々の 消化管ホルモン投与時、空腹時、あるいは食餌負荷後 における意識下の膵外分泌変動を、Herreraの方法に 準じて作成した慢性膵胃瘦犬を用いて検討してきた。 そこで今回、慢性膵胃瘦犬作成時にヒトの膵体尾部切 除に相当する約 $40 \%$ の膵左葉切除を合わせ行い、膵切 除後 1 ケ月および 3 ケ月の残存脺外分泌機能を、P S 試験などに較へるとより生理的な刺激と考えられる脂 肪酸十二指腸内負荷を用いて検討した。【方法】雑種 成犬10頭を用いて慢性膵胃瘦犬を作成した。そのうち 4 頭には約 $40 \%$ の膵左葉切除を同時に行い(膵切群)、 残りの 6 頭を対照群とした。両群において術後 1 ケ月 経過した時点で、18時間絶食の後、脂肪酸の一種であ るオレイン酸 $\mathrm{Na}(115 \mathrm{mM} 、 \mathrm{pH} 9.0) を 8.5 \mathrm{mmo} / \mathrm{hr}$ の速度 で 150 分間十二指腸内に持続注入した。榡液は15分分画 で採取し、液量・重炭酸塩排出量・蛋白排出量をそれ ぞれ測定した。さらに膵切群では術後 3 ケ月の時点で も同様の実験を行った。【成績】対照群・膵切群とも オレイン酸注入によって液量・重炭酸塩排出量・蛋白 排出量は注入前にくらべ有意に增加した。オレイン酸 注入中 150 分間の総膵液量は対照群の $85.6 \pm 14.6 \mathrm{mlK}$ 対して膵切群 1 ケ月には $42.3 \pm 11.0$ 纪低下傾向を示 したが、膵切群 3 ケ月では $62.8 \pm 9.9 \mathrm{m \ell}$.とやや回復が 認められた。総重炭酸塩排出量でも対照群 $5.76 \pm 1.41$ $\mathrm{mEq}$ に対して膵切群 1 ケ月で $2.45 \pm 0.77 \mathrm{mEq}$ 、膵切 群 3 ケ月で $3.95 \pm 0.76 \mathrm{mEq}$ と、総膵液量と同様の経時 的変化を示した。一方、総蛋白排出量においては対照 群 $1.53 \pm 0.17 \mathrm{~g}$ に対して、膵切群 1 ケ月 $0.86 \pm 0.21 \mathrm{~g}$ ・ 3 ケ月 $0.93 \pm 0.16 \mathrm{~g}$ と、膵切群では 1 ケ月・3 ケ月後 とも対照群にくらべ有意の低下を示した。【結論】膵 切除後の残存膵外分泌機能において、液量と重炭酸塩 排出量は膵切除後次第に回復してくるのに対して、蛋 白排出量は膵切除後 3 ケ月まで有意に低下したままで ほとんど回復傾向を認めなかった。ての結果より、腩 切除後の残存膵の機能的再生においては膵液分泌・重 炭酸塩分泌之醉素分泌之の間に時間的解離の存在する 可能性が考えられる。 
284

\section{与える影響}

上腹部自律神経叢切離が glucagon 分泌に

名古屋大学第一外科（* ; 現 琉球大学第一外科） 高江洲裕 $*$, 二村雄次, 早川直和, 大塚光次郎, 安井健三, 中山隆, 岡本勝嗣, 土江健翤司

目的）膵癌の手術において, 広範囲の神経凿郭清か 行われる傾向にある。一方, てのような神経叢郭清の結 果, 術後に耐糖能の低下や消化吸収障害か;頻発し, 術 後管理上の重要な課題となっている。そこで今回, 上 腹部自律神経叢切離が膵 glucagon (IRG)および gl ucagon like immunoreactivity (GLI) 分泌に与えろ影響 について検討した。対象と方法）雑種成犬30頭を用い 麻酔下で，1)単開腹のみの対照群 (C群), 2) 経腹的 迷走神経幹切離群 (V 群), 3) 上腹部自律神経叢切離群 (D群)の 3 群を作製し，20\%ブドウ糖溶液を 2 g/Kgで 十二指腸内へ注入し，十二指腸内ブドウ糖負荷試験を 行った。採血は肝門部門脈から行った。血糖を glucoseoxidase 法により，IRGを特異抗体 $30 \mathrm{~K}$, Total GL I を 非特異抗体 K4023 を用い, RIAにより測定した。gutGLI はTotal GLI とIRGの差とした。ゲル慮過を $1 \times 55 \mathrm{~cm}$ の Bio Gel P30 colum 使用し, glycine buffer 溶出に より行った。結果は mean土SEM で示し, $\mathrm{t}$ 検定を行い， $\mathrm{p}<0.05$ 有意差ありとした。結果)ブドウ糖負荷前の門 脈血中ブドウ糖濃度は C 群, V 群, D 群ともに $100 \mathrm{mg} /$ m前後にあった。ブドウ糖負荷後60分で頂值 (C 群 $: 165 \pm$ $13 \mathrm{mg} / d \ell$, V群 : $167 \pm 13 \mathrm{mg} / d \ell$, D群 : $212 \pm 18 \mathrm{mg} / d \ell$ ) に達し, D群は C 群と V 群に対し, 有意の高値を示した。 IRG 基礎值は 3 群ともに $180 \mathrm{pg} / m \ell$ 前後にあった。ブドウ 糖負荷後, C群とV群は IRG值の低下傾向を認めたが, D 群の IRG值は増加を示し, 60 分で頂值 $(357 \pm 53 \mathrm{pg} / \mathrm{m \ell})$ に達し,基礎值ならびにC 群と V群に対し有意の高值を示 した。gut GLI基礎值は 3 群とも $1000 \mathrm{pg} / \mathrm{m} \ell$ 前後にあ った。ブドウ糖負荷後60分で頂值 (C群 : $1686 \pm 285 \mathrm{pg}$ $/ m \ell, \mathrm{V}$ 群 : $1841 \pm 300 \mathrm{pg} / m \ell$, D群 : $5090 \pm 464 \mathrm{pg} / \mathrm{ml}$ ) に達し, D群はC 群と V群に対し, 有意の高值を示した。 血獎 IRGのゲル滤過像において分子量 (MW) >40000, $\mathrm{MW}=90000, \mathrm{MW}=3500, \mathrm{MW}=2000$ の 4 peak を認め た。ブドウ糖負荷後，各群とも主として $\mathrm{MW}=9000$ の IRG 増加を認め, D群はC 群とV 群に対し, 有意の高值 を示した。GLIのゲル滤過像においても 4 peakを認め た。ブドウ糖負荷後, 各群とも主として MW 8000 12000 GLI増加を認め, D群はC 群とV群に対し, 有意 の高值を示した。 結語）(11十二指腸内ブドウ糖負荷 試験において, 上腹部自律神経叢切離は血糖上昇に伴 うIRG の奇異上昇の一因となるととが認められた。

(2)ゲル滤過像において glucagon増加の主体はMW8000 -12000 にあり, 上腹部自律神経叢切離は主として GLI 分泌を促進するととが示唆された。
病態時の膵 Pros taglandin 代謝に及ぼす C CKの影響

信州大学医学部第 2 外科, ${ }^{1}$ 同薬理 ${ }^{2}$

○黑田孝井 ${ }^{1}$, 山岸喜代文 ${ }^{1}$, 梶川昌二 ${ }^{1}$, 堀米直人 ${ }^{1}$

安達 互 $^{1}$, 石坂克彦 ${ }^{1}$, 高橋千治 ${ }^{1}$, 飯田 $太^{1}$

堀内 朗 ${ }^{2}$, 岩月和彦 ${ }^{2}$

われわれは遊離膵を用いて膆とおける Prostaglandin (以下PG) 代謝に及㴗す CCKの影響を観察し,さらに 閉塞性黄疸時の膵につんても検討を加えた。

[方法] 10〜15kgの雑種成犬を用いて Pentobarbital 麻辕下に黄疸群( J群) は総胆管を結さつし, 対照群( C 群) 峰開腹のみを行い, 術後 2 週に以下の実験を行った。 Pentobarbital麻酔下に脺液採取の目的で主膵管にカニ ュレーションを行い,橋本らの方法により遊離膵を作製し， 灌流実験を行った。をずC群およびJ群の膵流入血およ び膵灌流後血を採取し, その後C群に対してCCK 2,4 お よび 8 Uを，J群に対してCCK 4 Uを灌流回路の動脈側よ り one-shot で投与し, 投与後 $1,3,5$ おび10分の時 点で膵灌流後血を 1 分間分画採取し, それぞれの $\mathrm{PGE}_{2}$ および 6-keto PGF $1 \alpha$ (6 $\left.6 \mathrm{kt} \mathrm{PGF}_{1 \alpha}\right)$ を RIA 法に て測定した。また, 別の実験群において Indome thacin $10 \mathrm{mg} / \mathrm{kg}$ を静注し，15分後に CCK 0.3，1 および 4 Uを 投与し, 前記同様の実験を行い, かつ, CCK 投与後 15 分間の膵液採取を行った。

[結果] C群におけるCCK投与前の膵灌流後血の $\mathrm{PGE} 2$ および $6 \mathrm{kt} \mathrm{PGF} 1 \alpha$ の值は膵流入血のそれらの值飞比較 して有意に上昇していた（ $\mathrm{P}<0.01)$ 。CCK 2, 4 および 8 $\mathrm{U}$ 投与後の脺灌流後血の $\mathrm{PGE} 2$ および $6 \mathrm{ktPGF} 1 \alpha$ の值 の変動は各投与群ともそれぞれ投与 3 分あるいは 5 分 後にピークを持ち, かつdose responseを示し，をた， J群におらても CCK投与前の脺漼流後血の $\mathrm{PGE}$ 2および $6 \mathrm{ktPGF}_{1 \alpha}$ の值は膵流入血のそれらの值に比較して有 意に上昇していた $(P<0.01)$ 。J群における CCK投与前後 のPGE 2 および $6 \mathrm{kt} \mathrm{PGF}_{1 \alpha}$ の值は C群に比較して有意に 上昇していた $(\mathrm{P}<0.05)$ 。Indomethacin 処置群における CCK投与前の膵流入血および脺灌流後血の $\mathrm{PGE} 2$ およ び $6 \mathrm{ktPGF}_{1} \boldsymbol{\alpha}$ の值の間には有意差はなく, CCK 投与に てもそれらの值は上昇を示さなかった。CCK 0.3,1お よび 4 Uで刺激した賸液量と Indomethacin 処置後, 相 対する量の CCKで刺激した脺液量との間には有意差を 認めなかった。

[結論] 1) 脺においては通常 $\mathrm{PGE} 2$ および $6 \mathrm{kt} \mathrm{PGF}_{1 \alpha}$ は 産生されている。2) CCKは脺におけるPG産生を促進す る。3)黄疸時, CCK とょる脺の PG 産生は克進してん

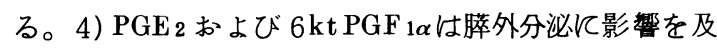
ぼさない。 


\section{急性膵炎症例の検討}

千葉大学医学部第 2 外科

浅野武秀、榎本和夫、剣持 敬、後藤剛貞、 中郡聡夫、圾本 䕌、落合武徳、渡辺一男*、 磯野可一（＊千葉県がんセンター）

教室では本邦での脺移植確立を目的として、イヌ部 分膵移植モデルを用いて種々の研究を施行してきた。 今回 pre-clinical studyとして、現在の腎移植ドナー での虚血条件にて脺移植が施行し得るかどうか検討し たので報告する。

方法 : イヌ同種部分膵移植モデルを用いた。温 暖虚血は心停止後 15 分ないし 30 分放置し作成した。 心停止前に、ヘパリン、及び抗蛋白分解酵素剤を投与 した。臟器泠却と血液のwash out は教室の死体内灌 流装置を用いて行なった。死体内灌流装置は口ーラー ポンプとアイスボックスよりなり、腎移植、実験肝移 植において使用している装置で、短時間で全腹腔内臓 器の冷却灌流を施行し得る。摘出部分膵はレシピエン 卜腸骨窝に移植し、膆管は膵管膀胼吻合法により再建 した。免疫抑制剂としてF５０６を用い、移植後空 腹時血糖、 I V - G T T、生着期間、組織学的検索を 行ない検討した。実験群。1 群 ） $\mathrm{n}=5$ ，W I T O分 対照群、2 群 ) $\mathrm{n}=5, \mathrm{~W} \mathrm{I} \mathrm{T} 15$ 分にて脺を摘出後 直ちに同種移植した群、3 群 ) $\mathrm{n}=5$,WIT 15 分に て摘出後 6 時間単純冷却保存した後移植した群、4 群) $\mathrm{n}=5, \mathrm{~W}$ I T 30 分にて脺を摘出し、直ちに同種移 植した群。

結果： 移植後空腹時血糖は 4 群とも、移植後 2 週まで全例正常に保たれ、各群間に差はみられなかっ た。 $0.59 / \mathrm{kg}$ glucose 負荷に依る I V-GTTでもK值 は、 1 群：1.27士0.41、2 群：1.21土0.28、3群 : $0.95 \pm 0.35 、 4$ 群 : $0.83 \pm 0.45$ であり、insul inogenic index (I. I ) でも、1 群: $0.048 \pm 0.025 、 2$ 群 : $0.047 \pm 0.035 、 3$ 群 : $0.035 \pm 0.016 、 4$ 群 : $0.028 \pm$ 0.032 と各群間に有意の差を見出し得なかった。しか し 4 群には K 値、I.I に於いて低值を示す例が存在 し、温暖虚血 15 分では障害はみられないが、W I T 30 分ではおこることが判明しだ。剖検時の組織学的 検索でも、2 群、3 群に於いては障害は軽度で、外分 泌、内分泌細胞とも良く保たれているが、4 群では、 内分泌細胞は比較的良く保持されているものの外分泌 細胞は変性し、線維化しており、虚血に依る障害がみ られた。

結論： 現在の腎移植はW I T 15 分以内、全虚 血時間 6 時間以内で行なわれて居り、これらドナーの 脺を用いて脺移值の可能性が示㖫された。

\section{鳥取県立中央病院 外科}

水本 清, 加藤一吉, 山本洋之, 岸 清志, 米川正夫

急性膵炎は、軽症のものより重症まであり、良性疾 患であるといっても、難治性であることを、経験させ られる疾患である。

今回我々は当病院、外科での過去 6 年 7 ケ月間の急 性膵炎症例を検討し報告する。

昭和 56 年 1 月より昭和 62 年 7 月までに当院外科で 経験した急性膵炎 20 症例を対象とした。内訳は、男 性 15 例、女性 5 例で膵炎の原因としては胆石性のも の 10 例、アルコール性のもの 5 例、術後性のもの 3 例、その他 2 例であった。厚生省特定疾患難治性膵疾 患調查研究班の分類によると軽症 3 例、中等症 9 例、 重症 8 例であった。治療に関しては、保存的治療のみ 施行 4 例、はじめに保存的治療を行いのちに外科的手 術療法を行ったもの 7 例、入院後ただちに手術施行し た症例は 9 例であった。 4 例が膵炎治庱開始後 1 ケ月 以内にMOFを併発して死亡した。死亡例はいづれも 重症型であり、手術施行症例であった。

以上より重症型膵炎は死亡率も高く、早期診断、早 期治療が大切であると考えられた。 
国立病院医療センター外科

秋山稔, 八幡和彦, 三好知明，原修， 仲佐 保, 田村 閏, 上村志伸, 谷昌尚,

安達秀治，川井三郎，浅野 哲

昭和 52 年から昭和 61 年までの 10 年間に国立病院医療 センターで経験した胆石膵炎症例は18例であり，てれ は同期間の急性脺炎症例47例の38\%にあたり，また胆 石症手術例1142例の $1.6 \%$ にあたる。

胆石糊炎症例を性別てみると男 7 例, 女11例と女性 に多く，年龄は25歳から80歳，平均60歳であった。胆 石の部位別でみると胆素結石のみ 5 例, 胆素十総胆管 結石 12 例，総胆管結石 (胆摘後) 1 例であった。

症状は，全例上腹部痛で発症し，悪心，嗑吐を伴う るのが 9 例に認められた。腹部所見では，全例に上腹 部圧痛を認め, 筋性防禦の認められたもの8 例, ブル ンベルグ徴候が 4 例に認められた。

入院時検査成績では，血清アミラーゼ値が560〜 5775 平均 $2765 \mathrm{U} / \mathrm{L}$ と全例上昇しており，乙れはアルコ ール性脺炎 $885 \mathrm{U} / \mathrm{L}$, 特発性脺炎 $1306 \mathrm{U} / \mathrm{L}$ と比へ有意 に高值を呈していた。血清ビリルビン值は 0.6〜 12.5, 平均 $3.3 \mathrm{mg} / \mathrm{dl}$ であり，入院時黄㾝を呈していたるのは 11例あった。

全例に対し手術が行われたが，手術時期では48時間 以内に行われた緊急手術例は 1 例のみで，その他はす へて待機手術例て，平均25日後に行われた。手術術式 では，胆亳結石のみの 5 例においては，胆摘術のみ 3 例，胆摘+総胆管切開+Tチューブドレナーシ術を 2 例に行い，後者のらち胆事十二指晹奱を呈していた 1

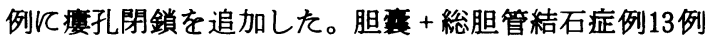

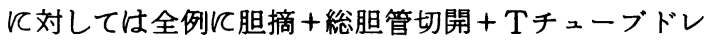
ナーシ術を施行した。

術後経過は16例においては良好であったが，術後出 血, 腹腔内脹疸を生じ 3 度の再手術が行われた症例が 1 例，遗残結石に対し総胆管十二指晹吻合術の行われ た症例が 1 例あった。しかし死亡例はなく全例軽快退 院した。

\section{【結語】}

1. 胆石膵炎18例を経験したので報告した。乙れは急 性膵炎の $38 \%$ ，胆石症手術例の $1.6 \%$ 亿あたった。

2. 胆石脺炎における血清アミラーゼ値は他の成因に よる膵资に比べ有意に高値を呈した。

3. 胆石脺炎18例全例に対し手術が行われたが，死亡 例はなく，予後良好であった。

\section{急性膵炎の治療成績 \\ 一遠隔時成績を中心に一 青森県立中央病院外科 \\ 小寺太郎、松本純、能登際}

過去15年間に当科で経験した急性腈炎61例を対象に 膵炎の治療成績、主に遠隔成績について検討した。 [対象および方法]急性膵炎61例の内訳は男39例、女 22例で年齡は平均48才であった。成因は胆道原性24例 $(39 \%)$ 、アルコール性16例（26\%）、外傷性 3 例 ( $5 \%$ )、不明、その他が18例 (30\%) であった。剖 検で始めて重症膵炎と判明した 3 例を除いた 58 例を 3 つの群すなわち I 群; 保存療法群 ( 17例 ) II 群 ; 保存 療法の後原疾患あるいは合併症に対して手術を行なっ た群 ( 16例)、置群; 緊急手術を要した群 ( 25例) に 分け検討を行なった。遠隔時調査は腹痛、糖尿病の有 無、体重、便通に関してはアンケート調査で、䐗内外 分泌機能検查、超音波検査は無作意に15名外来で施行 した。尚脺機能検査は退院後平均 9.2 年経過後のもの であった。〔治療および遠隔成績】I群は絶食、IMH、 経鼻胃管挿入、抗酵素剂投与などの保存的療法を行な った。II群は平均 2 週の保存的療法の後15例に胆道系 の手術を、1 例に腹腔ドレナージを行なった。群は 腹腔ドレナージ、膵授動脺床ドレナージが主術式で 7 例に外胆汁瘦を併施した。死亡例は12例（ $20.7 \%$ )で、 【群 1 例、血群11例であった。術前ショック、腹水を 伴うもの臨床検査で血糖、BUNの異常高值、C a の低 值を示した例の予後が悪かった。死因は【群の 1 例は のう胞破裂で四群ではショック 2 例、術後早期のDIC 3 例MOF 4 例、腹腔内膿瘍 2 例であった。また膡の 肉眼病型別の死亡率は浮腫型 2 例に対し出血壊死型13 例中10例 $(77 \%)$ と高率であった。一方急性膵炎の遠 隔成績は生存 46 例中 37 例にアンケートの回答が得られ た。結果は他病死 2 例を除く35例で腹痛有りが10例 (28\%) )、、糖尿病が 9 例（ $26 \%$ ）に認められたが総 合評価では良好 $69 \%$ 時々腹痛あるいは糖尿病で通院を 要する者 $29 \%$ 入退院をくり返す不良が1例（2.9\%）で あり I〜吕群間に差は認められなかった。一方膵機能 検査では 75g.O G T T で施行16例中 6 例 ( I 群 2、I 群 1 、林群 3 ) が糖尿病型を 2 例（ I、II群各 1 ) が 耐糖障害を示した。P F Dテストでは 6 例が低值を示 し特に群では 6 例中 5 例が低值を示した。また超音 波検査で胆石を 4 例（Ｉ群 3、四群 1 ) 亿膵石を正群 の 1 例に認めた。すなわち遠隔時の膵機能は I群は良 好で田群と I 群の原疾患を放置した例では低下してい ろ例が散見された。〔結論】门)重症急性膵炎、特に出 血壊死型の手術成績は極めて不良で先ずは早期の死因 であるショック、D I C、MOF〜の詨策が 治療成績向上 のポイントとなる。ii)急性膵炎遠隔時の膵内外分泌機能 は必ずしも良好とは言えず敩重な follow upが必要となる。 
神戸大学医学部第 1 外科, * Department of Pathology, Kuakini Medical Center, Hnolulu, Hawaii, **神戸大学医学部第 1 病理

清水道生, 林 卓司*, 伊東 宏**, 山本正博, 大柳治正, 斉藤洋一

1954年に terminal acute pancreatits として Sachar らが最初に10例の限局性急性膵炎を報告したが, それ 以後の文献は極めて少なく、本邦報告例はみられない。 しかしながら,急性膵炎の病理組織発生を解明するう えでこの病変の検索を行うことはきわめて重要と思わ れる。今回われわれは剖検应例を用いて, ”生前, 臨 床的に膵病変を認めず, 剖検時に初めて病理学的に認 められた限局性の急性膵炎”である Acute Terminal Pancreatitis の臨床病理学的検討を行ったので報告す る。なお, terminal pancreatitis (末期膵炎)を一つの entity と考え，そのうちの acute (急性)なむのという 考えから, acute terminal pancreatitis という用語を 用い, 日本語名は "急性末期膵炎”とした。

対象はハワイの Kuakini Medical Center で1982年 に施行された 108 例门剖検症例のうち, 膵癌症例, 膵 転移か著明な症例, 脺の autolysisが著明な症例などを 除いた76例である。76剖検例中10例の $13.2 \%$ 亿病理組 織学的に好中球を主体とした炎症細胞浸潤と腺房細房 の壊死がみられ、いずれの症例においても生前には臨 床的に膵病変はみられず,急性末期膆炎の定義に合致 した。年秢は56から80歳で, 性別では 6 例が男性で,

4 例が女性であったが有意差はみられなかった。

急性末期萃炎は種々の疾患の末期に発生すると思わ れるが, 10例のうち 4 例に直接死因としてショックが みられ有意な所見であった。また，大部分の症例で剖 検時に胆道病変・DICなど急性膵炎の臨床的要因と考 えられる背景因子が認められた。

病理組織像は臨床でみられる急性膵炎の組織像の最 も初期のものと考えられるが, 膵管周囲が炎症の主体 をなす periductal type と小菓辺縁部を中心に発生する perilobular type の 2つに分類された。共通所見とし ては腺房細胞壊死, 出血, 浮腫, 好中球の浸潤があげ られ, 前者ではタンパク栓を伴う拡張した膵管が特徴 的で，好中球浸潤は膵管内および周囲で著明であった。 一方, perilobular type では脂肪壊死が特徵的で, 好 中球浸潤は小葉の末梢側が主であった。以上の所見よ り, 急性膵炎の病理組織発生を考えるうえで, 少なく とも2つの発生機序,つまり, periductal typeにおけ る膵管を主体とした組織障害と perilobular type にみ られる小葉辺縁における腺房細胞の障害が存在するこ とが示唆された。
291 Scavenger の変動 急性脺炎の病態における Free Radical

京都大学第 1 外科

野中 敦, 真辺忠夫, 田村耕一郎, 浅野 昇, 山木健一郎, 平野鉄也, 戸部隆吉

急性勝炎の病態に，活性酸素が関与していることが 最近注目を集めているか，膵組織中におりる活性酸素 動態についてはあまり明らかにされていない。今回, コリン久乏性エチオニン投与マウスに於て, 膵炎を惹 起せしめ, 経時的に, 膵組織における活性酸素種の scavenger である Superoxide Dismutase (SOD), Catalase (CAT) 活性，並びに，過酸化脂質の変動を Malondealdehyde (MDA) を指標として測定し，急性 腈炎の病態亡活性酸素の関与について検討した。併せ て, 滕組織の Amylase の変動, 病理学的変化も観察 した。

〈実験方法〉実験には, BALB/C マウス（+ 11～22gr) を使用した。overnight の絶食の後, コリン久乏性エ チオニン経口投与勝炎を作成し， 2 時間毎に24時間ま で, 経時的にマウスを屠殺し, 膵組織を摘出, 摘出膵 を homogenate 後, Amylase と共に, SOD, CAT 活 性と MDA (TBA 法) を測定した。

<結果>(1) SOD 活性 (unit/mg • prot.) : control 群 $(4.076 \pm 0.215)$ に比し， 2 時間後 $(4.839 \pm 0.231)$ に 軽度の上昇 $(\mathrm{P}<0.05)$ を認めた後, 低下傾向を示し, 12時間後 $(3.26 \pm 0.160, P<0.05), 24$ 時間後 $(2.254$ $\pm 0.071, \mathrm{P}<0.001)$ には有意の低下を認めた。

(2) CAT 活性 (K/mg・prot.) : control 群 $(0.019 \pm$ 0.0029) に比へ除々に活性は低下する傾向を示し, 12 時間後 $(0.007 \pm 0.0009, \mathrm{P}<0.01)$ 24時間後 $(0.0034 \pm$ $0.00027, \mathrm{P}<0.001)$ には，有意の低下を認めた。

(3) MDA (n mole/ml) : control 群 $(2.63 \pm 0.78)$ に比し 4 時間後には，軽度の上昇を認めたが有意差なく，24 時間後には $0.77 \pm 0.09(\mathrm{P}<0.05)$ で有意の低下を認め た。(4) Amylase (unit/g・tissue)：6 時間後から上昇 傾向を示し，24時間後に peak に達した。組織学的に も膵炎の病像を確認しえた。

〈考察〉以上より，エチオニン膵炎における， active oxygen の scavenger (SOD, CAT.) の変動から，その 病態に活性酸素種が深く関与していることが示唆され た。活性酸素の産生による oxidative stress, 細胞膜 の過酸化による膜破壊から膵酵素の逸脱という，膵炎 発生機序の可能性が示唆されるが, MDA が 4 時間後 に軽度の上昇を認めるものの有意差がないてとより， 今後, 尚一首の検討が必要である。 
実験的急性膵炎の腎機能障害に関する検討 一特に血中レニン活性についてー

大阪市立大学第一外科, 同 薬理 *

日衰彰人, 金沢学秀, 西脇英樹, 佐竹克介, 梅山鳘，雪村時人*

腎組織の虚血はレニンーアンギオテンシン系を活性 化し，その結果として循環血流量・腎血流量の增大や 血圧上昇をきたす。今回われわれは実験的急性膡炎犬 において腎機能障害と血中レニン活性との関連につい て検討した。

方法：1）雑種成犬をネンブタール麻酔下に開腹し, 自家胆汁 $(0.5 \mathrm{~m} V \mathrm{~kg})$, t rypsin $(10,000 \mathrm{u} / \mathrm{kg})$ および自 家䏣汁 - trypsin混合液を用手高圧化で膆管内に注入 し，3 群の急性膆炎犬を作成した。2）連続的に血圧· 腎動脈血流量を測定した。3）作成前，作成後10分， 30 分，1，2，3，4，5 時間に動脈血・腎静脈血探血， 10分間尿探取を行った。4）イヌリンの動静脈湌度較 差により系球体滤過量（GFR）を測定した。5）血墏 を $0.1,0.2,0.5,1.0,2.0,5.0 \mathrm{mg} / \mathrm{ml}$ の $\mathrm{trypsin}$ と incubationした後，レニン活性を測定した。

結果：平均血圧は 3 群とも経時的に低下したが，自 家胆汁單独群では比較的保たれたのに対し, 自家䏣汁 -trypsin 混合群の低下は著明であった。腎動脈血流量 でも自家䏣汁 -trypsin 混合群の低下は著明であり, 1 時間後より有意の低下を示した。自家䏣汁単独群では 4 時間後より, trypsin 単独群では 3 時間後より有意の 低下を示した。糸球体法過量の変動は, 自家䏣汁単独 群では 5 時間後まで維持された。trypsin単独群は直後 より徐々に低下したが，有意な低下ではなかった。自 家䏣汁 -trypsin 混合群では 1 時間後より有意な低下を 認めた。尿量は 3 群とも著明に減少したが, 自家䏣汁 -trypsin 混合群の减少は10分後より有意であった。

末梢血のレニン活性は自家䏣汁単独群では30分後よ り増加し， 2 時間後で有意に増加した。trypsin単独群 の増加はわずかで, 自家䏣汁 -trypsin混合群では逆に 減少した。留静脈血のレニン活性は自家胆汁単独群で は末梢血同様 2 時間後より有意に增加した。trypsin 単独群の堌加は自家䏣汁単独群に比べわずかであった。 自家胆汁 -trypsin 混合群では減少した。

trypsin incubation 時の血永レニン活性はtrypsin の濃度には影翌されなかった。

まとめ：自家䏣汁, trypsin, 自家䏣汁-trypsin 混合 液の膵管内高圧注入により, 腎機能障害の程度の異な る実験的急性膆炎犬を作成した。自家䏣汁単独群, trypsin 単独群においては経時的な觜機能障害の増強 とともに血中レニン活性の上昇がみられたが，自家䏣 汁-trypsin 混合群では, 初期より血中レニン活性の上 昇はみられなかった。また，増加したレニンは trypsin incubationでも活性には変化はみられず, 大部分が活 性化レニンであるととが推測された。

\section{膵蒦胞症例の検討}

岐阜大学第 1 外科, 同臨床検査医学 ${ }^{*}$

尾関 豊, 鬼束惇義, 味元宏道, 矢野好弘,

日野晃紹, 林 勝知, 広瀬光男, 下川邦泰*

岐阜大学第 1 外科における最近 10 年間の膵雯胞症例 17 例（仮性雯胞 10 例, 真性袁胞 7 例)について検討し た。

成因別内訳：仮性衰胞のうち慢性膵炎に伴うもの 2 例, 急性膵炎後 1 例, 外傷性 3 例, 手術後 3 例, 腫垓 内出血による衰胞形成 1 例で, 真性高胞では撉胞腺腫 4 例（粘液性亭胞腺腫 3 例, 漿液性雯胞腺腫 1 例）,

旁胞腺癌 1 例, 眝留震胞 2 例であった。

年龄・性：旁胞腺腫の 4 例がすべて女性である以外， 特徽的な年齢分布・性差はなかった。

発生期間 : 仮性雯胞において腹痛発作, 外賃などか ら撉胞発生確認までの期間は, 不明 2 例を除く 8 例中 6 例が 1 力月以内であった。他の 2 例はともに術後発 生例で, 5 カ月と 1 年 3 力月であった。

臨床症状：仮性亳胞では腹痛, 発熱などの炎症々状 が主で, 真性震胞では腫留触知および腹部鼔満感のみ で炎症々状は認めなかった。

検査成績：アミラーゼ上昇, 白血球増多が仮性衰胞 で高率に認められたが, 真性蒦胞では認めなかった。 画像診断はUS, CT, とくにCTが有用であった。

発生部位・形状・大きさ：仮性・真性とも体尾部に やや多く，震胞腺腫の 4 例はすべて体尾部に存在した。 仮性衰胞は単発・単房性が 5 例ともっとも多かったが, 多発も 3 例と少なくなかった。腫嫁性熟胞は 5 例中 4 例が多房性であった。大きさは 1 から $18 \mathrm{~cm}$ までで, 腫場 性亳胞に大きなものが多かった。

内容液：色調には一定の傾向がなかった。仮性衰胞 は腫煌内出血例を除さすべて漿液性で, 真性雯胞は被 覆上皮の性状により奬液性と粘液性に分れた。ア之ラ 一ゼは仮性襄胞 7 例全例に高值を示し, うち 6 例が 1 万単位以上であった。真性震胞 3 例はすべて千单位以 下であった。

治療：13 例に14 回の手術を施行した。仮性震胞は意 胞胃吻合術 4 例, 脺尾側切除術 2 例, 外瘦術 2 例, 瘦 管空腸吻合術 1 例であった。2 例が自然退縮した。真 性喜胞は腫湯性隻胞 5 例全例に切除術を行った。画像 診断にて偶然発見された貯留亳胞 2 例は放固した。

手術成績：消息不明 2 例を除くと, 霞胞腺癌が 7 年 6 力月再発死亡した以外, 全例生存中である。

まとめ：1）教室における脺旁胞17例を検討した。2) 仮性亭胞の発生期間は 1 力月以内が多かった。3）仮性 亭胞は炎症々状が主で血中および旁胞液中アミラーゼ が高值であった。4)真性衰胞は腫留を主訴とし,炎症所 見は認めなかった。5)仮性衰胞はわもに内瘦術, 真性 軎胞は切除術を行い, 比較的良好な結果であった。 
長崎大学第二外科, 同医療技術短期大学部 西浦清昭, 前田治伸, 富岡 勉, 小原則博, 元島幸一, 山本堅輔, 山口孝, 井沢邦英, 角田 司, 原田 昇, 土屋凉一, 伊藤俊哉 ${ }^{\star}$

最近の各種画像診断法の進歩普及に伴い，膵算胞性 疾患の診断は容易となり，その症例は増加の傾向にあ る。今回膵筇胞のうちでも比較的に稀とされている真 性喜胞の自験例を対象として, その病態と治療の現況 を報告し，その遠隔成績を報告する。

昭和 36 年以来, 当施設において経験した膵衰胞性疾 患は 85 症例であり, Howardらの分類に従うと，仮性重 胞 60 例, 真性䆣胞25例であった。今回対象とした真性 重胞の内訳は，先天性と考えられるものワ例，眝留重 胞 4 例, そして腫瘍性重胞14例であった。先天性衰胞 のうち2例は叔母姪の関保にあるLindau氏病症例で,

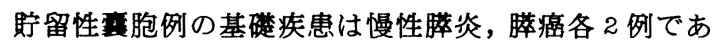
り，また腫瘍性童胞では，童胞腺腫 3 例 (serous typo I例, mucinous type 2例), solid and cystic tumor （SOT）工例，重胞腺癌10例などがその主なものであっ た。これらには胆管狭宏 5 例, 局所性門脈圧六進 3 例, 十二指腸狭窄 工例などの合併病変の存在を認めたが， その自覚症状としては, 体重減少や腫瘤触知, 上腹部 痛などが主なものであった。

外科治餈を行ったものは 24 症例であり，それぞれの 病態や基磷疾患に応じて, 荟全摘工例, 膵体尾部切除 14例，重胞切除 3 例，造袋術工例などを施行した。特 に腫瘍性塞胞例では14例中几例が切除可能であった。 直死例はなく, 遠隔時の死亡を四例に認めたが, 現在 14例が生存中である。この死亡例の死因は膵癌や零胞 腺癌の再発等が 8 例と最も多く, 以下消化管出血 2 例 などがその主なものであった。

以上真性膵臺胞25例の治療経験より，画像診断の進 歩普及に伴い膵留胞の存在診断自体は容易となってき たが，腫瘍性や先天性重胞例では今なおその質的診断 は困難な症例も多い。一方眝留性重胞ではその基礎疾 患と塞胞の存在診断は比較的容易であったが, 所謂膵 仮性要胞との籃別診断は術中においてさえも困難であ った。

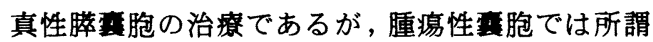
mucinous cystic tumorを中心として, 良悪性の判然 としない症例も多いため可及的切除が望ましく，また 䝪留性素胞では基礎疾患に対する外科治療が重要と考 えられた。一方先天性重胞例においても, 所謂 polycystic dieaseや Lindau氏病を除くとその術前の 質的診断は困難な症例も多いので, 可及的に切除の方 針にて臨むべきものと考えられた。
295 血清および裏胞液中 CA 19-9・CEAが 高値を示した巨大膵真性衰胞の一例

一京都第一赤十字病院 外科一 天池 寿, 栗岡英明, 谷向茂厚, 竹下和良, 赤見敏和, 生内一夫, 堀井淳史, 池田栄人, 西本知二, 武藤文隆, 橋本京三, 大内孝雄, 田中貫一，原田善弘，伊志嶺玄公

腫場性膵衰胞は, 比較的稀な疾患であり, 現行の種 々の手段を用いても, 術前診断, 質的診断, 手術方法 亿苦虑する事が多い。最近我々は，血清および塞胞液 内の CEA，CA 19-9が高値を示した症例を経験したの で報告する。

\section{症例 : 35 歳 女性 主訴 : 上腹部腫瘤}

既往歴：膵炎, 腹部外傷なし。急性虫垂炎。

現病歴: 昭和 57 年頃より心窩部痛出現するように なり, 本院にて精査, 膵衰胞を指摘され, 手術を勧め られるも放置。腫瘤の大きさは時に消退消失する事が あったが, 約 2 年前より除々に增大し, 消失しない為 来院，手術目的で入院となる。

入院時現症：体格中等度, 栄養良好。黄疸なし。上 腹部膨瘤著明, 同部に表面平滑, 弾性硬, 呼吸性に移 動する約 $20 \mathrm{~cm}$ 径の腫瘤を触知する他特記所見認めす。

検查所見: 末梢血, 肝胆道醭素に異常なく炎症所見 あ認めなかった。血清アミラーゼは $123 \mathrm{U} / \mathrm{l}$, エラス ターゼ I $208 \mathrm{ng} / \mathrm{ml}$ 。耐糖能正常, 腫瘍マーカーは血 清 CEA が $2.4 \mathrm{ng} / \mathrm{ml}$ 。CA $19-9$ が $2000 \mathrm{U} / \mathrm{ml}$ と異常值 を示し，衰胞液ではCEA $90000 \mathrm{ng} / \mathrm{ml}$, CA 19-9 $79 \times 10^{5} \mathrm{U} / \mathrm{ml}$ であった。組胞診では Class II 〜II。超音 波, CTでは, 膵体尾部より薄い壁を有し, 内腔に隔 壁構造の認めない豪胞を認めた。上部消化管造影では, 胃は左後方より壁外圧排像を認め著しく偏位していた。 ERPでは，膵管は体尾部の下方圧排を示すも，震胞と の交通，内腔の不整・断裂はみられなかった。以上よ り真性膵変胞之診断し, 膵体尾部・襄胞切除を予定した。

手術所見：昭和 62 年 6 月 25 日局麻下にドレナージ手 術施行後，6月 29 日根治術を行った。衰胞は腹壁との疹 着軽度。脾臓とは一体化しており, 左副堅も強固な病 着のため, 膵体尾部, 脾・左副腎合併切除を施行した。 周囲への浸潤, リンパ節転移の所見は認めなかった。 摘出標本では, 平滑な内壁の一部に乳頭様增殖と, 脾 臟への穿通が認められた。病理組織は，膵管上皮様細 胞を有する真性膵亳胞で, 乳頭様增殖部には, 壁内浸 潤を示す focal malignancyを認めた。

術後, CEA, CA 19-9は23 PODには各々0.5 ng/ml $76 \mathrm{U} / \mathrm{ml}$ まで低下し，33 PODにて軽快退院した。

結語 : 腫揚性膵衰胞例に, CA 19-9等の異常值を認 める報告が最近諸家より行われているが，その意義に ついては明らかでない。今回 CA 19-9 と膵変胞・膵腫 瘍との関連について若干の検討を加え報告する。 
296 膵の solid and cystic tumorの一治験例 群馬大学第 2 外科

竹吉 泉, 宮本幸男, 竹下正昭, 小堀抬雄, 水口滋之, 棚橋美文, 込谷淳一, 泉勝, 蒔田富士雄, 井上智博, 川井忠和, 泉雄 勝,

1981年 K löppe1らによって報告された膵の稀な腫 瘍 solid and cystic tumor と思われる症例を経験 したので，現在までの報告例に文献的考察を加え，報 告する。

〔症例〕 55 才 女性

[主訴]心裔部痛

〔現病歴〕昭和 61 年 6 月頃より，空腹時心窩部痛あ ったが放置。61年 11 月上腹部痛, 背部痛及び嘔吐 あり近医受診。胃透視並びに腹部超音波検查施行し膵 腫瘍及び十二指腸潰瘍を疑われた。その後 C T施行し 膵腫場の所見あり。同年 12 月当科紹介入院となった。 [ 入院時現症]体格は中等度, 眼瞼結膜賓血なし, 眼 球結膜黄㾝なし，心肺異常なし，腹部は平坦軟で胵瘤 は触知せず。

[検查所見]血中アミラーゼは正常でそのほかの生化 学的検查も正常範囲内であった。腫場マーカーは，C $\mathrm{EA}: 1.9 \mathrm{ng} / \boldsymbol{m} \ell, \mathrm{CA} 19-9: 22 \mathrm{U} / \boldsymbol{m} \ell$, AFP : $2.6 \mathrm{ng} / \mathrm{m} \ell$ と正常範囲内であった。腹部超音波検査では 膵頭部に直径約 $5 \mathrm{~cm}$ の腫瘤を認め内部エコー不均一で あった。腹部 C T 椿查では膵頭部に境界鮮明で腫瘍の 中心部付近はlow density を呈していた。血管造影 では腫煌濃染像を認めた。E R C P は十二指腸潰瘍に よる狭窄のためファイバー通過せず造影できなかった。 超音波誘導下細胞診では adenocarci nomaの疑いで あった。以上より膵頭部腫場の診断で昭和 61 年 12 月 18 日手術施行した。

〔手術所見】膵頭部から体部の頭側に直径 $5 \mathrm{~cm}$ ほどの 波動を有する腫瘍を認めた。肝，リンパ節等には転移 はなかったが術前の細胞診でClass N のため膵頭十二 指腸切除術を行なった。

[切除標本]大きさ $5 \times 4 \times 4 \mathrm{~cm}$ の腫瘤で明瞭な被膜 におおわれ、割面は淡い暗赤色のゼリ一状の液体より なり、一部充実性で黄白色部分及び線維成分に富む部 分よりなっていた。

[病理所見]線維性被膜でおおわれた cystic なtumor の内壁に小〜中型の核と好酸性胞体を有する細胞が

sol id に增殖。血管内に腫瘍細胞が多く被膜に浸潤 がわずかにみられた。特殊染色ではPAS. Alcianblue Lysozyme染色は陽性であり、 $\alpha_{1}$-antitrypsin は陰性 であった。電䫓的には Zy mogen 顆粒はなかった。

本腫瘍は，ほとんどの症例が若年女性にみられ予後 良好な腫瘍とされているが、我々の収集しえた 70 症 例の報告例に文献的考察を加えて報告する。
297

$$
\begin{aligned}
& \text { 膵の solid and cystic acinar cell } \\
& \text { tumor ( SCAT)のl 治験例 }
\end{aligned}
$$

群馬県立がんセンター 外科

中村 茂、阪上昌三郎、木村盛彦、福田敬宏、

一色重雄、清水幸夫、小井田時広

同 病理杉原志朗

1981 年、K工öppe1 らが提唱した裹胞性膵腫韵 SCAT は若年女性にみられる稀な疾患で、悪性度の低い予後 良好な腫演とされている。

今回、我々は本症と思われる1例を経験したので、 その臨床的、病理学的特徴について検討し、若干の文 献的考察を加えて報告する。

症例は 50 歳の女性、 3 年前から食後の心嵩部もた れ感あるもそのまま放置していた。1986 年 8 月 27 日当院初診。腹部エコー、 C T 等より毫胞性膵腫境が 指摘された。1986 年 9 月 24 日の入院時所見では、貧 血、黄瘨、体重減少等はなく、右側卧位にて左季助部 に $5 \times 4$ 横指大の腫㢞が触知された。血液、尿、生化 学検查で異常なく、AFP、OEA、CA19-9、IAP等の腫 珸マーカーも正常域内であった。

胃造影では、胃体部小弯後壁に压排像がみられた。 腹部エコーでは、膵体尾部に超手拳大の類円形、境界 が比較的明膫で、不規則な内部エコーを伴う腫傹像が あり、 $\mathrm{OT}$ でも同样の所見で、大小不揃いの low density areaからなり、腫煌の辺縁部は enhance さ れたが、中心部はむしろ久損していた。ERCPでは、 腫湯の手前で主膵管の中断像がみられた。血管造影で は、腫瑒による脾動脈の挙上と脾静脈の圧排像がみら れ、また膵体尾部に淡い腫㗢陰影が認められた。

以上の所見より、膵体尾部の衰胞性腫汮のうち特に SCAT 疑い、1986 年11月12 日膵体尾部切除、脾 摘術が行われた。腫湯は表面平滑、弾性軟、 $12 \times 9 \times$ $7 \mathrm{~cm}$ 大の被胞性腫㷎で、周辺組織への浸潤、転移お よびリンパ節腫大は琹められず、割面では実質性の部 分と壊死で旁胞状になった部分が混在し、凝血塊や薄 茶色のゼリー状内容液が認められた。

組織学的には、腫煌細胞は類円形の小型の核をもち 、淡い好酸性の胞体を有する上皮性腫堨細胞が cystic または soliaなcell nestを形成し增生している。一部 血管周囲に乳頭状に增殖しているところもある。また、腫 瘍細胞は mitosis に乏しいが、一部正常膵実質への浸 潤傾向がみられた。PAS染色は陽性であったが、 $\alpha_{1}$-Antitrypsin、OEA、NSE、Keratin等の免疫組織学的染色 pGrimelius染色は陰性であった。電影的には豊富な mitochondriaと、zymogen様顆柆が認められた。

以上より本腪湢は膵体尾部より発生した SCATと診 断された。本症はリン八節転移はな、術後10力月の現在 健存中であるが、被膜外への漫潤傾向もあり悪性の potentialも否定できない。 
岡山大学第 1 外科

森隆, 高倉範尚, 三村 久, 坂田龍彦 細羽俊男, 津下 宏, 岡林孝弘, 浜崎啓介 折田薰三

1975年から1987年 9 月までに教室で経験した慢性膵 炎手術症例22例のうち合併症による手術例は, 胆管狭 窘 5 例, 膵囊胞 2 例, 食道静脈瘤 1 例, 十二指腸狭窑 1 例の計 9 例である。今回はこれらの合併症をとり上 げ, 治療上の問題点について検討し, 症例を呈示する。 (1) 胆管狭窄 ( 5 例)：4 例は術前画像, 術中検索に て慢性膵炎と確骖されたが，1例は膵癌誤診例である。 術式は膵頭十二指腸切除 3 例, 膵全摘 1 例, 胆管十二 指腸吻合 1 例であったが, 膵切除 4 例中 3 例は膵頭部 主膵管に比較的限局した狭窄があり，しかも有疼痛例 で胆道のみならず膵管減圧も必要と考えられた。しか し, 胆管十二指腸吻合を行った 1 例も萃頭部主膵管に 限局狭窄が認められたにも拘らず, 現在まで特に症状 なく経過しており，てのような苏頭部に限局した病変 を有する胆管狭窄例に対する手術術式にはなお問題点 もあると考えられた。

(2)膵囊胞（ 2 例 ) : 仮性膵囊胞は 6 例に認めたが， 2 例は自然消失した。震胞に対する手術例は 2 例でいず れも囊胞消化管吻合を行ったが, 術後経過は良好であ る。全ての囊胞が外科手術の対象ではなく, 自然消失 する例もあり，US，CTにより経過を観察したい。 (3)食道静脈㿔（1例）：血管造影を行った 22 例中 3 例 に上腸間膜静脈あるいは脾静脈の閉塞を認めたが, 門 脈圧元進症に基づく症状を呈した例は 1 例にすぎなか った。多くは徐々に求肝性の側副血行が形成されるた めと考えられ，特に門充症による明らかな所見がなけ れば放置してよいと考える。手術症例は30才, 女性で 心窩部不快感を主訴に来院。上部消化管内視鏡検査で 食道静脈瘤があり, 血管造影では脾静脈および上腸間 膜静脈に閉塞を認めた。E R C Pでは膵体部主膵管の 拡張があり, 食道静脈瘤に対し, 摘脾・食道離断術・ 血行郭清を行った。

(4)十二指腸狭窄（1 例）：慢性膵炎に続発する十二指 腸狭窝の報告は比較的稀である。自験例は57才, 男性 で, 嘔吐, 上腹部痛を主訴に来院した。諸唡査にて慢 性膵炎による十二指腸狭窄と診断し開腹した。狭窘は 膵頭周囲の炎症性癒着によるものであったが, 膵頭十 二指腸切除術を行った。

慢性膵炎に続発した合併症に対する治療法の選択に はなお問題点もある。われわれの経験した症例を呈示 し考察する。

\section{近畿大学第 2 外科}

森下明彦, 園部鳴海, 笠原 洋, 中谷公一, 浦田尚巳, 上田省三, 中尾稀一, 竹本雅彦, 山田幸和, 田中 茂, 須藤峻章, 久山 健

はじめに：勝切除に際して脾を温存し得る場合があ り，とくに膆良性疾患に用いられる。脾の血行支配上 からみて, 熷動静脈を温存しての膵切除, 脾動静脈を 切離して左胃大網動静脈ないしは短胃動静脈からの血 流に期待, これらの動静脈をすべて切離のうえで脾の 血流を後腹膜より求める, の 3 つの方法があげられて いるが，実際の施行報告例は少ない。その理由は手技 の煩雑な面に加えて, 種々の合併症もみられるからか と思われる。最近の 1 例と他の 2 例について報告する。 症例：第 1 例 58 歳 女性, 上腹部痛を主訴とし, 前医にて膡尾部の毫胞性疾患を $\mathrm{CT}$ 上指摘され, 昭和 62 年 4 月に入院。US にて勝尾に $2.5 \times 2 \mathrm{~cm}$ の蕒胞がみられ, ERCPではその旁胞と主膵管との交通が証明された。 選択的腹部血管造影では著変はなかった。同年 6 月 10

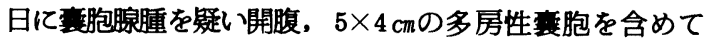
膵尾切除を行ったが, 脾は温存し, 脾動静脈も切離しな かった。組織診断は眝留性衰胞であった。術後 10 日目 に強い左上腹部痛を生じ, 血清アミラーゼ值が 1,694 IU と上昇した。USにて脾に接しての衰胞がみられ, 脾 門部に残存の膡組織からの仮性衰胞形成と思われた。 保存的療法により次第に軽快をみた。第 2 例 48 歳 男性, び慢性の膆石症を伴う慢性勝炎の患者で, 初回 のドレナージ手術後に腹痛の再燃と難治の十二指腸皮 庙瘦がみられた。昭和 59 年 8 月 1 日に膵全摘を施行し たが, 術後経過は良好であった。なお脾動静脈は温存 した。第 3 例 36 歳 女性, 慢性腈炎で前医にて胃表 胞吻合を昭和 53 年 11 月に受けたが, 左側腹部痛の再燃 がみられ, 同 59 年 6 月に当院入入院。CT で膡尾の石灰 化と衮胞を指摘され，ERCPでは串胞と主膆管の間に 交通がみられた。選択的腹部血管造影では慢性膡炎か凝 われ，慗胞部の血流は乏しかった。仮性萁胞の診断で 同年 7 月 9 日に開腹, 衰胞部を含めて膆尾切除を行っ た。脾は脾動静脈を切断の上で温存したが, 術後経過 は良好であった。術後 21 日目の腹部血管造影では, 左 胃動脈の拡張がみられ, 同動脈を介しての脾血流の存 在が確認された。

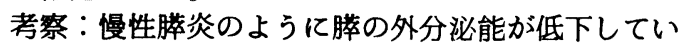
る場合には, 脾温存膵切除においての脾周囲に残存の 膵組織に由来の合併症は生じにくいと思われる。乙れ に対して、䐗組織が未だ正常の状態に近い病変にわい て脾の温存を計るとさには，自験の第 1 例のような仮 性震胞の合併をみることもあり, 脾温存の方法に注意 すべきと思われた。 
膵全摘後 8 年間経過した一例

王子総合病院外科，市立苫小牧病院内科 ${ }^{*}$ 下沢英二，佐藤一義，大坂喜彦，暒谷道夫， 高橋透，皆上宏俊 ${ }^{*}$

疾患の如何にかかわらず膵全摘の適応となる症例は 少なくない。膵全摘により救命し得た後はその内外分 泌機能が欠落するため, 血糖コントロールと消化吸収 の面で綿密な長期管理が必要となる。しかしその管理 は容易ではなく，長期生存例が未だ少ないてともあり , 各種の問題点は未解決のままである。我々は重症慢 性膵炎に対し膵全摘施行後 8 年間を経過した症例を経 験したので，てれら問題点を検討し報告する。

\section{症例：40才男}

26 才時上腹部痛にて発症, 以后年に数回の疼痛発 作を繰り返し当院内科で慢性膵炎の診断で治療してい た。32才時，急性増悪の状態で各種保存的治療です 疼痛の寬解が得られず，39 C〜40 Cの高熱と白血 球增多が続を当科入転科した。全身状態が次为に悪化 するため昭和 54 年 11 月 20 日手術に踏み切った。 膵管狭さくはなく実質全体上り膿汁の漏出をみたため 脺全摘を施行した。組織学的には高度の炎症性細胞浸 潤を伴 5線維化であり腺粠造は殆んど失われているが ラ島は僅かに残存していた。術後敗血症その他の合併 症を克服し 8 年経過後の現在生存している。

術后の血糖コントロールは, 術直後はR I 40 単位 /日の点滴静注を行ん, 経口摄取開始後はN P H 20 単位/日皮下注グルカゴン $0.5 \mathrm{mg}$ 投与したが，F B S は $200 \mathrm{mg} / \mathrm{dl}$ 以上であつた。1 年経過後，イン スリン持続皮下注療法（Nipro，S P - 3 使用）を開始 し，MCアクトラピッドを Base 8.6 単位, Plus 4.5 単位 $\times 3$ で投与した。F B S $100 \mathrm{mg} / \mathrm{dl}$ となった が，日中は $300 \mathrm{~m} / \mathrm{d} 1$ と高かつた。 5 年後より合成 ヒトインスリンを用い, Base 15 単位, Plus 6 単位 $\times 3$ で投与，血糖は $200 \mathrm{mg} / \mathrm{d} 1$ 以下のレベルとなり HbA1 $10 \%$ 前後で安定した。現在Base 10 単位， Plus 6 単位 $\times 3$ でコントロール中である。患者が次 第に低血糖発作の発現を予知するようになり間歇的に 自分で注入速度を調節するよらになり，極度の低血糖 発作は最近みていない。一方，栄養吸収障害に基く低 蛋白血症（TP 4.1，A $1 \mathrm{~b} 2.8 \mathrm{~g} / \mathrm{dl}$ ) と浮腫が常時み られ全身管理の為 6 ケ月毎の入院を必要としている。

まとめ：膵全摘後の血糖調節はヒトインスリン持続 皮下注により比較的良好であるが，尚低血糖発作の危 険性は残り患者自身のインテリシェンスと家族の協力 が不可欠である。さらに外分泌機能欠損に基く栄盖管 理は難泳を極めているのが現状である。従つて膵全摘 患者の管理には糖尿病専門医の参加が不可欠であり、 外科医による一般術後管理の範囲をてえている。
301 腫瘜随伴性膵炎の臨床的及び病理学的検 討 一ラ島における細胞構成比の変動について一

京都大学医学部第一外科、同医療技術短期大学 部**、山口大学医学部第二外科 *

加治 弘、宮下 正、井上一知、鈴木 敞* 戸部隆吉、高橋清之**

腫瘍随伴性膵炎は膵頭十二指腸切除後の膵内分泌機 能を予測するうえで重要な因子であるがその研究は従 来、二次性慢性席炎の一部として他の慢性膵炎之一括 して病理学的に論じられてきたのみである。今回私達 は腫瘍随伴性膵炎の臨床的重要性に着目し、過去の手 術症例について臨床的、病理学的検索を同一症例を通 じて行なった。【対象】当科で昭和55年から昭和60年 の間に、脺頭十二指腸切除ないし膵全摘を行なった膨 大部癌 6 例、膵頭部癌 12 例を対象とし、糖尿病のない 胃癌患者で、膵合併切除を行なったもの 6 例をcontr ol群とした。【方法】対象症例（膵体部）を線維化の 程度により分類した（Grade 0:なんら線維化の認め られないもの、Grade I : 主として小葉間結合織増生 を示すむの、Grade II ：小葉間結合織増生に加えて 小葉内結合織增生の認められるもの、Grade III：小 葉内外の結合織増生が著明で、ほとんど膵実質の萎縮 消失をきたしたもの）。それぞれ免疫組織学的手法 (間接法)を用いて、B細胞、 $\mathrm{A}$ 細胞、 $\mathrm{D}$ 細胞を染色し た。それぞれの切片につき有核細胞数50以上のラ島 30 個について有核細胞総数 : $\mathrm{T} n 、 \mathrm{~B}$ 細胞数 : $\mathrm{Bn} 、 \mathrm{~A}$ 細 胞数 : An、D細胞数 : $\mathrm{Dn} 、(\mathrm{n}=1 \sim 30)$ を光影下 にカゥントし、B細胞比 $(100 \times \Sigma \mathrm{Bn} / \Sigma \mathrm{Tn}) 、 \mathrm{~A}$ 細胞比 $(100 \times \Sigma \mathrm{An} / \Sigma \mathrm{Tn}), \mathrm{D}$ 細胞比 (100 $\times \Sigma \mathrm{Dn}$ $/ \Sigma \mathrm{Tn})$ を算出した。臨床的データには術前行なった 経ロブドゥ糖負荷試験（OGTT）及び同時に測定し た血中インスリン値（I R I ）を用いた。【結果】 con trol群 6 例、Grade 03 例、Grade I 6 例、Grade II 5 例、Grade III 4 例についての結果; B細胞比はそ

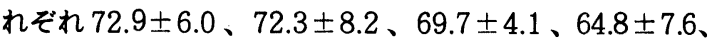
$50.6 \pm 8.7 、 \mathrm{~A}$ 細胞比はそれぞれ $26.9 \pm 4.0 、 23.3 \pm 5.4 、$ $24.7 \pm 2.3 、 25.2 \pm 8.3 、 31.5 \pm 5.3 、 \mathrm{D}$ 細胞比はそれぞ れ $8.1 \pm 1.4 、 8.9 \pm 1.9 、 8.1 \pm 1.8 、 8.1 \pm 2.5 、 9.1 \pm$ 1.4 であった。膵の線維化がすすむにつれてB細胞比は 減少し、A 細胞数は增加傾向を示し、D細胞数にはほ とんど変化がみられなかった。OGTTでは膵線維化 が進むにつれて血糖の最高値に達するまでの時間が延 長し、Grade III ではほとんどの症例が linear patternを示した。IRIでも各GradeにおいてOGTT に相当する変化がみられた。【結論】腫瘍随伴性脺炎 ではD細胞比にはほとんど変化が見られなかったが、 $\mathrm{B}$ 細胞比の減少及び $\mathrm{A}$ 細胞比の增加傾向がみられ、こ の現象が耐糖能低下をきたす要因となるととが示晙さ れた。 


\section{神戸大学第 1 外科}

塚本好彦，鈴木康之，藤原英利， 清水道生, 石田常之, 田中龍彦,

山本正博, 大柳治正, 斉藤洋一

過去15年間に当教室で経験した慢性膵炎94例のうち， 膵石症27例を対象に慢性膵炎の一病態としての膵石症 の本体を明らかにし, 術式, 予後から治療上の問題点 について考察を加えた。

神戸大第 1 外科で1971年〜1986年までの15年間に経 耠した慢性膵炎症例は94例であり,そのうち膵石症は27 例(28.7\%)であった。性別は男23例, 女4例と男が圧 倒的に多く，年命分布では30〜40歳代が16例(59.3\%) を占めた。成因ではアルコール性 23例, 非アルコール性 4 例とアルコール性が多かったがこれらは慢性膵炎全 体と差はなかった。膵石非合併例では20\%が疼痛以外 の主訴であったのに対し，膵石例では95\%が疼痛を主 訴とした。病悩期間をみると 1 年以上のものが膵石合 併例では80\%，膵石非合併例では50\%と膵石合併例 が長かった。膵内外分泌機能に関しては, 膵石合併例 では, 内分泌異常 $64 \%$, 外分泌異常 $32 \%$ と膵石非合併 例に比し有意に内外分泌異常を示す症例が多かった。

膵石症を建部らの分類に従い，小結石，大結石，混 合型に分け、さらに存在形態により,び漫型, 限局型 に分類し，それらの特異性について検討した。成因や 年踚、性にはとくに差はみられなかった。病悩期間は, 大結石型では短く，小結石，混合型は長いものが多か った。また病悩期間の長いものに膵管拡張例が多かっ た。膵内外分泌機能では大結石，小結石とも約半数が 異常を示したのみであったが，混合型では，内分泌異 常が70\%に, 外分泌異常が90\%に認められた。また， アルコール性のものでは70\%に膵管抾張を伴ってみら れたが, 非アルコール性は全例に膵管拡張が認められた。

手術々式は，膵管拡張例に対しては，主として膵管 空晹側々吻合術が, 膵管非抾張例で病変が限局してい るものには膵切除術が施行された。膵管非拡張例で かつ混合型の膵石がび漫性に分布するアルコール性膵炎 2 例に対しては膵頭部切離兼膵体尾部授動術が施行さ れた。疼および膵内外分泌機能に対する遠隔時成績 では，23例(85.2\%)に手術の効果が認められた。予後 不良例は全例アルコール性脺炎で膵管拡張を伴っており, び漫性の小結石型であった。

以上，膵石症は病悩期間が長く，内外分泌機能障害 を示すものが多かった。特にアルコール性で, 小結石び 漫型には，経過不良例もみられることから，術式の選 択には十分なドレナージまたは除痛効果が得られるよ う配虑する必要がある。

\section{国立岡山病院外科}

古城資久, 浦上 淳, 松森秀之, 萱野公一, 大住省三，且井由行，池田敏夫，東 良平， 谷崎真行, 佐々木澄治, 西 純雄

膵頭部領域の悪性腫瘍との鑑別に苦慮する疾患とし て膵頭部腫瘤形成性脇炎が知られている。近年画像診 断の進歩に伴い，乙の二疾患の診断能は向上したが， やはり鑑別の困難な症例が存在する。昭和59年 1 月よ り62年 9 月までに当院にて膵頭部癌 5 例, 膵内胆管癌 2 例, 乳頭部癌 2 例, 腫瘤形成性膵炎 2 例, 計11例の 膵頭部疾患の手術が行われた。今回は腫瘤形成性膵炎 の 2 例及び術中に慢性膵炎と診断したが再手術にて膵 頭部癌と判明した 1 例を供覧し考察を加えた。

第 1 例は51才大酒家の男性，腹痛にて紹介された。 画像診断にて膵頭部に限局性の腫瘤が疑われ，C A 199 ，エラスターゼ 1 が高值を示したため脺頭十二指腸 切除（以下 P D ), リンパ節郭清を行った。膵頭部に $3 \mathrm{~cm}$ 径の硬い腫瘤を認めたが, 組織学的には慢性膵炎 であった。術後腫瘍マーカーは速やかに低下した。

第 2 例は74才大酒家の男性で, 肝硬変, 糖尿病の加 療中に無痛性胆袁腫大を来たし紹介された。C A 199 ，エラスターゼ 1 がやや上昇していたが， C T ， E R C P で慢性膵炎の所見が明らかで, 膵内胆管のしめ つけ像の距離も長く, 慢性膵炎と診断した。しかし経 過中に黄疸が出現し胆管炎を併発したため胆囊摘出術, 総胆管十二指指腸吻合術を行った。術中の朖頭部針生 検で悪性所見を認めず, 腫瘍マーカーも術後より速や かに低下した。

第 3 例は腹痛, 黄疸を主訴とする56才女性。膵頭部 癌を疑い開腹したが膵はび慢性に硬化しており腫瘤様 病変を認めず，3 3 所の術中針生検でも悪性所見を得 ず，慢性膵炎と診断し総胆管十二指腸吻合術のみを行っ た。しかし術後生検部より膵液瘦を来たし，十二指腸 狭窄も起ったため膵液ドレーナージ後に P Dを行った。 組織は膵癌であった。

画像診断技術の向上にもかかわらず鑑別が困難な膵 頭部病変はやはり存在する。胆道疾患を伴う症例では 腫瘍マーカーも確実な指標となり得ず，胆汁，膵炎の 細胞診も炎症のある場合は判定が難しい。術中生検む 診断に適する組織が得られるとは限らない。しかし安 易に拡大手術に走らず，十分な術前診断を行い，腫瘤 形成性膵炎と診断し，保存的治療に反応しない屯のは 胆道ドレナージ手術を行うことが望ましい。しかし開 腹時の視診，触診では鑑別不能な症例む多く，術中の 迅速標本による診断が欠かせない。術中生検技術の向 上に努力したい。また要性疾患が疑われる時はP Dを 行うが，そのリンパ節郭清が問題である。まずP Dだ けを行い確診を得てからリンパ節郭清にうつるなど過 大な侵襲にならない工夫が必要である。 


\section{乳頭部癌切除例の検討}

北海道大学第二外科

児嶋哲文, 高橋利幸, 平 康二, 立石 直

鈴木雅行, 奥芝俊一, 阿部一九夫, 加藤紘之 田辺達三

昭和 50 年より昭和 62 年 8 月まての当科におけるファ 一タ一釈頭部䄆切除例25例につレて検討した。特に, 当科ては昭和 57 年以後, 尾側䐁遊離法脺頭十二指腸切 除術（遊離法 PD）を開発し賸癌のみならず中下部胆 管癌，乳頭部癌にも施行してをたのて，リンパ節転移 を中心に遠隔成績と臨床病理学的検討を報告する。

<対象 >昭和50年より昭和56年の標準的郭清を伴な う膵頭十二指腸切除術（標準法PD）例が 9 例, 遊離 法PDが 16 例の合計 25 例である。

<結果> Stage 別内訳は Stage I 2 例, Stage II 18 例, Stage III 2 例, Stage IV 2例であり, Stage决定因子は胆道 癌取扱い規約第 2 版により, N,Panc, Dであり，病理組 織所見を加味した。リンパ節転移をみると， $\mathrm{n}_{0} 13$ 例， $\mathrm{n}_{1} 8$ 例, $\mathrm{n}_{2} 2$ 例, $\mathrm{n}_{4} 2$ 例であった。膵減浸潤は panc 8 例， panc 14 例, panc 21 例, panc 1 例, 不明 1 例 であった。十二指腸浸潤は， $\mathrm{d}_{0} \beta 2$ 例， $\mathrm{d}_{1} \alpha 4$ 例， $\mathrm{d}_{2} 18$ 例, 不明 1 例であった。

全耐術例 21 例の 5 年生存率岎約 $40 \%$ てあり， 3 年以上 生存した 4 例は全例再発るな生存中でり $\mathrm{n}_{0}$, panc $_{1}$ て脺実質浸潤のない症例であった。， $\mathrm{n}_{0}$ 群は $\mathrm{n}(+)$ 群に 比へ明らかに予後良好であり, 又 $\mathrm{n}_{1}(+)$ 群の予後す比 較的良好で，24 ケ月，20ケ月生存中などの例がある。

再発死亡例は11例であるが，肝肺などへの遠隔転移 が多くみられた。大動脈ないし上腸間膜動脈周囲リン 八゚節（＃16，\#14)への転移を認めた 4 例は，レずれる 癌死しており, 肝転移を 2 例に, 肺転移を 2 例に, 後 腹膜再発を 2 例に認めた。

部位別にみたリンパ節への転移率及び転移度は（\% 一\%) は以下の如くであった。\# $12: 4.2 \%-8.7 \%$, \# 13 a : 40\%-15.2\%, \# 13 b : $23.1 \%-11.5 \%$, \#14:20\% $-13.2 \%, \# 16: 10 \%-1.8 \%, \# 17$ a $: 10 \%-8 \%$, \# 17 b : $25 \%$-28\%。 その他のリンパ節への転移はみられな かった。全体で転移率は25例中12例，48\%であり，

転移度は 1106 ケ中 48 ケて $4.3 \%$ であった。\#14(+)は 4 例であり，この内 2 例が\#16(+)であった。この 2 例 は, 各々 panc ${ }_{0}, d_{2} ;$ panc $_{1}, d_{2}$ であった。

<考案>今回の検討では乳頭部癌の予後壮 $\mathrm{n}$ 因子, panc因子により大をく影敕されるが， $\mathrm{n}_{1}(+)$ 例の予後が 必ずしす不良でないこと， $\mathrm{n}_{4}(+)$ 例にみた如く術前術 中に癌の進行度は予測でさないことなどより積極的切 除を行ない成績向上を追求することが重要である。又， 遠隔転移に対する化学療法, 後腹膜再発予防に対する 放射線治療などの今後の付加療法が必要と考える。
305 る検討

十二指腸乳頭部癌の予後決定因子に関す

都立駒込病院外科

小原徹也、岡本篤武、鶴田耕二、小野寺時夫 神前五郎

昭和51年11月か562年 8 月まてに経験した十二指腸 乳頭部癌26例 (男12例、女14例) 几ついて手術成績な らびに予後決定因子に関して検討した。手術々式は膵 頭十二指腸切除術24例（切除率 $923 \%$ ) 2 例は高令お 上び肺転移のため胆管空腸吻合術を行った。

肉眼型と panc・d・n の各因子との関係を見ると非露 出腫瘤型お上び露出腫瘤型は panc が79 \%、noが64 のであるのに対して、腫瘤潰瘍型お上 び潰疸腫瘤型では panc $_{2}$ 以上が $38 \% 、 d_{2}$ 以上が $90 \%$ 、 $\mathrm{n}_{1}$ 以上か $70 \%$ を占め、腫瘤型に比へて潰瘍形成型は 進展度が高度であった。

他病死 2 例を除いた22例の予後を検討すると 5 生率 は41\%、全例 panco noで組織型は高分化型腺痹であ った。各因子別で見ると pancoは 5 生率 70 力である のに対して panc 1 以上では 2 年 9 ケ月以上の長期生存 例はなく膵浸潤は軽微です予後は極めて悪かった。n に関してる同様て no の5生率は 75\%であるのに対し $\mathrm{n}_{1}$ 以上では 2 年生存が 10 例中 2 例のみであった。 panco no 05 生率は 87.5\%であった。一方d因子は do $\odot 5$ 生率は $100 \% て d_{1}$ 以上飞比べて有意飞高かっ たが、長期生存例 7 例中 $d_{1} \cdot d_{2}$ が 5 例す含をれてお り pancやn汪どは予後に影㫫していなかった。また 膵内神経周囲浸潤pn因子について見ると pn (一) の 5 生率 67 \% 亿対し pn (+) は 23 \%て有意差を認めた。 panco no の90\%がpn(ー)であるのに対してpanci 以上または $\mathrm{n}_{1}$ 以上で $\mathrm{pn}(+)$ が83\%に認められた。

再発形式に関しては腹膜播種が最も多く、その他肝 門部再発、肺転移、脳転移が認められ、特に肝門部再

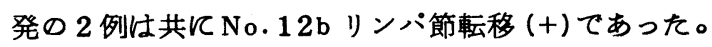
[結語]

十二指腸乳頭部癌は膵浸潤やリンパ節転移を認める 之膵癌同様にその予後は不良であるが panconoであ れば良好な予後が期待できる。手術術式壮膵痹に準じ たリンパ節郭清が必要て、進行癌に対しては術中術後 照射を含阵補助療法を行うのも一法と思われる。 
無黄疸の十二指腸乳頭部癌の 1 例

犬山中央病院外科! 龟田絵合病院外科, 名古屋 大学医学部第一外科; 昭和大学医学部外科 4 山瀬博史，稲垣喜治! 三品佳也，村上雅彦? 田辺大明, 菅野壮太郎, 飯島佰司 ${ }^{2}$

キサントグラニュローマ䏣资は䏣瓷瘦との鑑別診 断に難涉するととがあるが，今回経皮経肝䏣重鏡検查

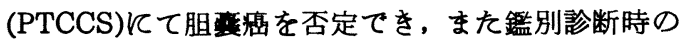
ERCP て十二指腸乳頭部に非露出腫瘤型の乳頭部㾮を発 見し根治切除がでをた症例を経験したので報告する。

症例: 50歳, 男性主訴: 上腹部痛

既往歴, 家族歴：特記すべをととなし。

現病歴: 1986年 9 月 16 日, 飲酒後突然上腹部痛が出 現し来院した。症状は一過性で改善したがCT, USて 䏣菱壁の肥厚を認め悪性病変を疑い鑑別診断を施行した。

$\mathrm{CT}$ : 䏣罴壁は肥厚し造影飞て壁内面が染まり, 壁内 が一部Lowとぬける所見を示した。

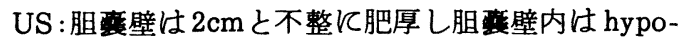
echoicであった。結石陰影を 1 コ認めた。

血管撮影：胆敦動脈に広狭不整を認めた。

以上より，䏣犦癌の鑑別診断のためPTCCSを施行した。

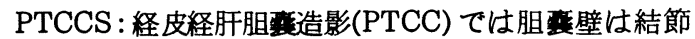

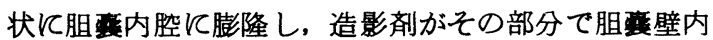
に一部流出した。PTCCD後 5 日目にPTCCSを施行し 䏣落内腔を観察すると覀性像 (不整な隆起性病変, 尾 瘍血管)は認めず, 直視下生検でも癌が陰性であった。 以上より, 他の画像診断とあわせ，䏣壁の肥厚は炎 症性変化によるキサントグラニュローマ䏣变炎と診断 した。また，鑑別診断のために施行したERCPにて， 十二指腸乳頭部の腫大, 開口部の発赤, 細顆粒状の粘 膜変化を認めた。強く㾇を疑い, 生検でも螅が陽性で あり, 非露出腫瘤型の十二指腸乳頭部㷎と診断した。 CT, US, 血管撮影では乳頭部には所見を指摘でをな かった。

以上より，キサントグラニュローマ䏣整炎を伴う十 二指腸乳頭部癌之診断し，1986年11月 27 日, 膵頭十二 指腸切除を施行した。

切除標本 : 䏣は壁が $1 \mathrm{~cm}$ に肥厚し，壁内に黄色の 結節を認めた。䏣襄壁全層で炎症反応が強くformy cell の集ぞくを認め, キサントグラニュローマ䏣雚炎 と診断した。䏣嘦内にコ系混合石を 1 コ認めた。十二 指腸乳頭部癌は非露出腫瘤型でOddi筋に僅かに浸潤す る $\mathrm{n}_{1} \sim 3(-)$ の乳頭腺癌であった。

患者は10カ月を程過した現在元気に社会復帰している。

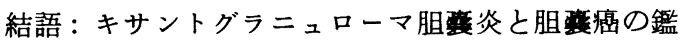
別診断にPTCCSが有用であった。鑑別診断時のERCP 飞て十二指腸乳頭部の腫大より, 比較的早期の乳頭部 瘦を発見でを根治できた。
北海道大学第 2 外科

鈴木雅行, 高橋利幸, 平 康二

立石 直，奥芝俊一，児嶋哲文

阿部一九夫, 加藤紘之, 田辺達三

最近の進歩した画像診断法に加え, 内視鏡やエコー を駆使した組織学的検索にても確診が得られず, 膵頭 部癌疑診例とされる症例がある。このような症例に対 する術式決定は, 術中生検により決定されてきたか， 従来，膵頭部の術中生検を行なう場合，部分切除によ る生検がをされてきた。しかし脺頭部での部分生検は 目的とする部位の検体が十分採取されない可能性が高 ケ。教室では確実な術中診断を得るため膵頭部に対し ても主脺管を含めた膵完全離断による生検法が必要と 考え, 膵頭部癌疑診例に対して膵頭部完全生検法を施 行してきた。今回, その意義と問題点につを検討を加 えたので報告する。

1)手 技：われわれは本法を膆頭部完全生検法と呼ぶ が, 術式は膵頭部を完全に遊離後, 術中エコーを施行 し, 術前の画像と合わせ, 目的とする部位を完全離断 する。すなわち病理一提出される膰組織仕主膵管を含 めて輪切り状に切除される。病理診断後，適切な術式 を決定するが，ここまでの操作は各術式を施行する際 の防げとなることはない。

2) 結 果: 6 症例に膵頭部完全生検を施行した。2 例 は本法により膵癌と診断されたか， 2 例とも $\mathrm{T}_{1}$ 症例で あった。他 4 例は慢性膵炎の診断を得たが，1例は長 年にわたり膵炎発作を繰り返していたため教公ての慢 性脺炎手術である脺頭部分切除兼体尾部遊離ドレナー シ法を施行した。術後の経過㤌 1 例に膵夜漏出を認め たが，他の症例では合併症の発生はなかった。

3）考察とまとめ：膵頭部完全離断による生検にて確 実な質的診断が得られた。膵頭部を遊離後に膵離断を 行なうため, 膵断端面および主膵管の処理が十分に行 なうことが可能でり，膵頭部完全生検法は比較的安 全で確実な質的診断が得られる方法であると考える。 さらに本法は, 病理診断後の適切な術式を施行する際 の妨げにならず有用な方法と考えられる。6 例中 2 例 がT膵癌であり本法が有用であった。最近各種画像診 断法の進歩により術前診断される $\mathrm{T}_{1}$ 症例が増加してい るが, 脺頭部領域に対して施行される本法は, 組織診 断を加えた画像診断にて確診のつかない症例に対する 有効な診断法でるあるといえる。以上，教室て施行し ている膵頭部癌疑診例に対する膵頭部完全生検法につ レて報告する。 
国立病院四国がんセンタ一外科 ${ }^{1)}$ 同病理 ${ }^{2)}$

金 隆史, 高嶋成光, 村上正和, 石田数逸

大田垣純, 棚田 稔, 曾我浩之, 原 史人

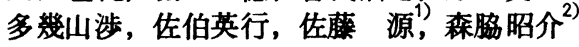

画像診断法の進歩, 各種腫焬マーカーの登場により, 滕癌の診断は著しく向上したが，小勝癌の発見は容易 ではない我々は腈管の拡張により診断した最大径 8 mmの島細胞由来と思われる小滕癌を経験したので報告 する。

症例：5 3才, 男性。眩晕を主訴に近医を受診したが, 精査のため施行した腹部C Tにて膵管の拡張が見られ たため，当科を紹介された。入院時栄養良好で，黄疽 はなく検查データー, 腫瑒マーカーとも全て正常值で あった。ERCP では，勝頭部主膵管の約 5 mm 狭窄 と末梢膵管の执張が認められ，狭窟部で主膵管の圧排 像を認めた。CT，エコー，血管造影では腫湯を同定 する所見は認められず，勝夜の細胞診る陰性であった。 以上より，賸癌つ確診はつかないものの，限局性の膵 管狭窄に対して手術適応があると考えた。術中所見で は, 腫瘤は触知でさす勝頭部の硬度の軽度增加と, 体 尾部の勝管の拡張が認められた。術中膵液の細胞診は 陰性であったが，勝頭十二指腸切除を施行した。摘出 標本では, 膵頭部の主膵管に接した最大径 $8 \mathrm{~mm}$ の小膵 癌を認め割面肉眼所見は硬化型, 浸潤性発育型であっ た。組織学的には, 腫煌組織は島細胞に類似し小胞巣 を形成して結合織增生を伴い浸潤性に発育し, 島細胞 由来の癌と診断した。被膜浸潤, リンバ節転移は認め ず, 術後 9 ケ月の現在, 再発の徴侯はない。
309

原発性十二指腸癌 4 症例の検討

杏林大学第 2 外科

鈴木 具, 鍋谷欣市, 花岡建夫,

中田芳孝, 小口晋平, 小林義泡

十二指腸痹は比較的まれな疾患であり，多くは発見 時すでに進行癌の場合が多い。昭和 52 年 1 月から昭 和 62 年 6 月までて当教室で経験した十二指腸癌数は 13 例であった。発生部位は乳頭上部 3 例, 釉頭部 9 例, 乳頭下部 1 例であった。今回, 十二指腸乳頭部癌 の 9 例を除く 4 症例 (球部早期癌 2 例, 球部進行瘦 1 例, 上行部進行癌 1 例) 飞ついて報告する。

症例 1 ：7 2 歳男性。易疲労感, 食欲不振を主訴々 して近医を受診し，十二指腸球部の出血性腫癌を指摘 され当科を紹介され入院となった。高度賓血を認め, 上部消化管検査にて十二指腸球部に母指頭大のカリフ ラワー状腫瘤を認めた。生検にて腺癌の診断をうけ, 十二指腸球部を含めた胃要全摘術を施行した。病理診断 では十二指腸球部後壁に存在する山田 $\mathrm{N}$ 型の高分化型 II a 様早期十二指晹球部癌であった。

症例 $2 ： 62$ 歳男性。既往歴飞 53 墄, 早期噴門部 癌飞て噴門部切除術, 61 歳, 胆衰内結石飞て胆衰切 除術を施行されている。噴門部切除による逆流性食道 奖症状のために上部消化管検查を施行され，十二指腸 球部に小指頭大腫瘤を発見された。生検にて腺癌の診 断をうけ，十二指腸球部を含めた幽門部切除術を施行 された。腫場は球部後壁小等寄りの小指頭大山田正型 のボリープで, 病理診断では高分化型のIa 様早期十二 指腸球部癌であり, 異時性胃十二指腸重複癌であった。

症例 $3: 73$ 歳女性。與下困難を主訴とし来院した。 上部消化管検査にて Bor rmann 3型の胃噴門部癌であり, 食道浸潤による食道狭窄を伴っていた。胃体上部およ び幽門輪直前にも山田 $N$ 型ポリープを認めたが, 食道 狭窄のため内視鏡検査は不可能であった。手術時十二 指晹球部にも鵎卵大腫瘤を認めたために，十二指腸球 部を含めた胃全摘術を施行した。病理診断では噴門部

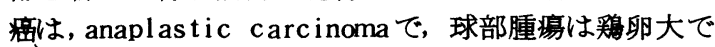
Bor rmann 1 型様の乳頭状腺瘦であり, 同時性胃十二指 腸重複痹であった。

症例 $4: 72$ 歳女性。湢吐を主訴に来院した。十二 指腸上行部を閉塞する進行性十二指腸瘦であった。手 術は十二指腸部分切除を施行した。十二指腸上行部に 沺大の Borrmann 3 型樣癌腫を認めた。

文献的考察では, 早期十二指腸㾔は, 症例 1，2 如く, ポリープ状の隆起性病変が多く, 潰瘍性病変は 少なかった。また, 腺腫内瘦を認める症例も多かっ た。一方, 進行十二指腸癌は, 症例 4 亿見るよ 5 に Bor rmann 3 型様の潰瑒形成型が多く, 症例 3 の如く Borrmann 1 型は少なかった。

以上十二指腸癌 4 例 (早期癌 2 例, 進行瘦 2 例) を 報告し，若干の文献的考察を加えて報告する。 
310 超音波内視鏡を用いた食道癌の壁深達度診断 東京医科歯科大学第一外科 下重勝雄，斉藤直也，竹下公矢，吉野邦英， 滝口 透, 河野辰幸, 山崎 繁, 鈴木知行, 山際明暢, 遠藤光夫

食道癌の壁深達度て知ることは, 治療法の選択, あ るいは予後の推定を行う上で重要である。深達度の診 断法は, $\mathrm{X}$ 線像, 内視鏡像等の間接所見から行う方法 と, C T 検査, 超音波内視鏡検査 (以下 E U S ) など のように，直接所見を得る方法とがある。さらに後者 に関しては，EU Sの方がC Tに比しより直接的な所 見を得ることができる。我々は，EUSを用いて食道 癌壁深達度の診断を行い, その有用性について検討を 加えたので報告する。【対象】1987年2月より8月ま で間に入院した食道癌症例のうち，25 例にE U S 検査を行ったここのうち, 手術治療を行い, 病理学的 検索を行い得た 24 例を対象とした。男女比は 23 対 1 で, 平均年令は64 才であった。【方法】使用機種 はオリンパスーアロカ社製 G F - U M 2 ( ラジアル式) でる。バルーン密着法により, 食道壁の連続的観察 を行った。壁深達度の判定基準は次の様に設定した。 1) $\mathrm{m}$ : 第 3 層が正常に保たれている場合。2） $\mathrm{sm}$ : 第 4 層が正常に保たれている場合。3） $\mathrm{mp}$ : 第 4 層の 菲薄化を認める場合。4） $A_{1}$ : 第 4 層の途絶を認める も，第 5 層に変化のない場合。5） $A_{2}$ : 全層に及ぶ構 造の破壊があるものの, 周囲臓器との境界が明瞭な場 合。6） As : 周囲臓器との境界が不鮮明な場合。以上 の方法で得られた壁深達度のE U S 診断と, 病理組皚 像による深達度診断とを比較検討した。【結果】内視 鏡が病変部を通過した症例は 24 例中 18 例 ( $75 \%$ ) であった。通過症例の壁深達度の診断率は全体で72 \%であっだ。その内訳は, $\mathrm{m}$ 癌=100\%, $\mathrm{sm}$ 癌= $100 \%, \mathrm{mp}$ 癌 $=33 \%, \mathrm{a}_{1}$ 癌= $=0 \%, \mathrm{a}_{2}$ 癌 $=80 \%$, $a_{3}$ 癌 $=50 \%$ あっった。不通過症例 6 例のうち, 5 例 は $a_{2}$ 癌, 1 例が $a_{3}$ 癌であった。このうち, 内視鏡の最

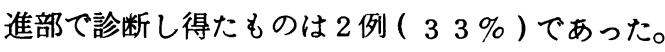

【考案】診断率が高いのは $\mathrm{m}$ 癌, $\mathrm{sm}$ 癌, $\mathrm{a}_{2}$ 癌である。 $\mathrm{sm}$ 癌, $a_{2}$ 癌に関しては, その特徵的所見が描出され易 いためと考える。しかし， m癌に関しては病変として 認識できない場合も多く, また, e p と mm の区別も困 難である。一方 $\mathrm{mp}$ 癌の診断率が低いのは,その病的変 化が画像上描出しにくいためと考えられる。a 症 例 10 例に限ってみると, 8 例 ( $80 \%$ ) が正診されて いる。これに対し, 不通過症例を含めた $a_{1}$ 以上の症 例 14 例についてみると, その診断率は $50 \%$ と低下 してしまう。 $a_{1}$ 以上の症例に関しては, CT検査を含め た複合診断が重要であると考える。【まとめ】E U S はその通過性に問題があるものの, 豊富な臨床情報て 提供してくれる極めて有意義な検査法である。
311 食道のリンパ流-SPECT を応用した RI-lymphography によろ検討一

岡山大学第一外科

岡信孝治、淵本定儀、上川康明、合地 明、 友近 浩、遠迫克明、前田徹也、椎木滋雄、 折田葶三

\section{同放射線科}

河野良宽、平木祥夫、青野 要

〈目的〉食道癌の合理的りンパ節垶清をおこなうために

Single Photon Emission CT(SPECT)を応用した経内 視鏡的RI-lymphography ( ${ }^{99} \mathrm{~m} \mathrm{Tc}$-rheniun colloid)を施 行し食道リンパ流の検索をおこなうと共に食道癌切除例 のリンパ節転移様式と比較しその臨床的意義を検討した。 〈対象と方法〉1986年7月より1987年9月までに当科で手 術を施行した食道癌14例(Iu:3例、Im:7例、Ei:2例、Ea:2 例)、肺癌3例、胃癌5例を対象とした。食道癌症例では周 在性が2/3周以下の10例において腫瘍占拠部対側の健常 部位に、また腫場が全周性ないし要全周性の5症例では腫 瘍の口側または肛門側にR I を注入した。

肺癌症例においては主として食道から肺気管支方向へ のリンパ流を検討した。RI注入後約3時間でSPECTを用 いて撮像し、また食道、気管、肺、野のscintigraphy も併せ ておてないリンパ流を三次元的に把握した。また、手術当 日には郭清リンパ節すべてのRI-UPTAKE を測定した。 〈結果〉全症例22例中最もよく移行を認めたのは気管分 岐部リンパ節(107)の17例(77\%)で、ついで胸部気管リン パ節(106)の15例(68\%)であった。腫演占拠部対側に打ちこ みをおてなった症例中頸部リンパ節へはIu注入群で83\%、 Im注入群で40\%、Ei注入群で17\%、また腹部リンパ節へは Iu注入群で 0\%、Im注入群で 30\%、Ei注入群で100\%の移行 を認めた。また、Im上部注入例ではIu注入例に、Im下部 注入例ではEi注入例に類似したリンパ節への移行を示し た。Im部食道に注入をおてなった肺癌3症例の検討では すべて、肺癌取扱い規約における葉気管支周囲リンパ節 (\#12)までの移行を認めたがそれより末梢肺への流入はわ ずかであった。腫場によろ壁在リンパ流のブロックが予 想されろ全周性ないし覀全周性の症例では、注入部位 上方に病柴を認めたIu注入例 1 例において腹部へ、また 下方に病柴の存在したEi注入2例において钼部リンパ節 へのRIの移行を怨めた。一方、当科で1972年2月から 1987年7月までにN 2 群以上のリンパ節郭清のなされた52 例の検討では、うち29例(56\%)にリンパ節転移を認めた。 また部位別ではIu部症例で2例腹部にEi症例で1例頸部 に転移が認められたが、いずれも全周性で右以上の症例 であった。〈結語〉Im部食道において上部例ではIu症例 に、また下部例ではEi症例に類似したリンパ節へのRIの 移行を示した。また食道癌のリンパ節転移様式に壁在リ ンパ流のブロックが大きな役割を果しているととが示 晙された。 
$312 \mathrm{CT}$, 経皮的頸部・上縦隔超音波，内視鏡 超音波による食道癌リンパ節転移の検討

国立がんセンター外科

日月裕司，加藤抱一，渡辺寛

頚部を除く食道の扁平上皮癌切除例 10 例 (Iu 2例， Im 5例，Ei 3例) に対して術前にCT，経皮的頸部・上 縱隔超音波検査および内視鏡超音波検査を施行し、頸 部および縦隔リンパ節転移診断と手術，病理所見を対 比し、それぞれの有用性を検討した。

切除された全リンパ節 721 個のうち組織学的に37個 に転移を認めた。このうち頸部リンパ節では 258個の 内 3 例 6 個に転移を認め、CTで 1 個、経皮的超音波で 2 個を診断しえた。診断しえなかった 4 個は径 $5 \mathrm{~mm}$ 末満 のものであった。内内視鏡超音波検査は描出能，患者の 苦痛に問題が有り、頸部リンパ節の検討に適さなかっ た。経皮的超音波で描出可能な大動脈弓上縁より頭側 の上縦隔リンパ節では摘出された107個のうち10個 に転移を認めた。このうち腕頭動脈背側の右反回神経 に沿った右縦隔最上部には3例 5 個の転移を認め、CT で4個，経皮的超音波で3個を診断しえた。内視鏡超 音波では診断しえなかった。この部の転移りンパ節は 腫大することが多く、全例診断可能であった。大動脈 弓上縁より頭側の左反回神経に沿った左傍気管リンパ 節には 2 例 5 個に転移を認めた。この部の転移りンパ 節は腫大することが少なく、径 $10 \mathrm{~mm}$ 以上に腫大した 1 個のみ診断可能であった。左上綎隔は経皮的超音波で は描出困難であったが、内視鏡超音波では描出良好で あった。大動脈弓より尾側の縦隔リンパ節では摘出さ れた167個のうち8個に転移を認め、CTで 2個，内視 鏡超音波で 4個を診断しえだ。CT では気管周辺の № 106, 107, 109 のリンパ節の描出は良好であったが、 中下部食道周辺のリンパ節の描出能は低かっだ。内視 鏡超音波では、大動脈弓，肺動脈の間でボタロー靫帯 内側の “いわゆるボタロー”リンパ節と中下部食道周 辺のリンパ節の描出能に優れていたが、2例で内視鏡 超音波が癌部を通過しなかった。

頸部および縦隔リンパ節転移の診断率は、CT $33.3 \%$ であったが、観察可能の領域での診断率は超音波検査 が優れており、観察可能の領域に限る経皮的頸部・上 縦隔超音波検査 $37.5 \%$ ，内視鏡超音波検査 $50.0 \%$ であ り、3者併用により転移リンパ節 24 個のうち 11 個 （ $45.6 \%$ ）が診断可能であった。
313 いた食道凉の顠部リンパ節転移の診断

福岡大学第 2 外科

蒲池寿、三尾寿樹、蝴晴久、左野千秋、

内藤英明、平林雅彦、神代龍之介、犬塚貞光

食道癌のリンパ節転移の頻度は高率であり、䫫部、 腹部への跳躍的転移をしばしば認める。我々は顠部り ンパ節郭清の必要性を主張報告してきた。今回、以前 より実施してきた甲状腺経由リンパ節造影を改良し、 チャコール添加（CH40）リピョドール注入改良型甲 状腺経由リンパ節造影法を考案した。

目的：食道癌のリンバ節転移は希ではなく、特に䫫 部リンパ節転移の有無を明かにする為、我々はリピョ ドール注入甲状腺経由リンパ節造影法をおこなった。 さらに、チャコール添加リピョドールをもちいた改良 型甲状腺経由リンパ節造影を考案し、この造影法が術 中の完全な頸部リンパ節郭清をおこなうに有用か否に ついて検討した。

対象と方法：対象は当科にて胸部食道痹切除術をう けた 42 症例を用いた。透視下に甲状腺両葉にリピヨ

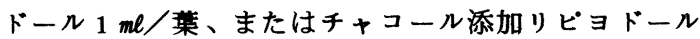
$1.5 \mathrm{m \ell} /$ 葉を $25 \mathrm{G}$ 注射針で注入し、経時的に頸部 $\mathrm{X}$ 楾 撮影を行いリンバ節の造影状况を钼察した。チャコー ル添加リピヨドール注入症例では、䫫部リンパ節郭清 は造影後的 1 週目に実施し、術中直視下に黒染したり ンパ節および不染リンパ節を確認のうえ郭清街を実施 した。

結果および考察：頸部 $\mathrm{X}$ 線撮影において異常造影り ンパ節の出現頻度は $47.5 \%(20 / 42)$ であった。異常 造影が認められた 20 例中 13 例が鎖骨上窝 (下内深頸) リンパ節の異常であった。また異常造影が認められた リンパ節の $50.0 \%(10 / 20)$ に痹の転移を諗めた。リ ンパ指向性のチャコール添加リピョドールを注入した 4 症例では、約 1 週目に䫫部リンパ節郭清を実施し、 全例リンパ節へのチャコールの取り込みが認められ、 直視下に完全なリンパ節郭清が可能であった。また、 転移部分は一部チャコーnの不染部分を生し、、枟移り ンパ節の確認も可能であった。

結語：1）甲状腺経由リンパ節造影を施行し、造影 リンパ節の $48.9 \%$ に異常造影所見を認め、その 52.4 \%に癌の転移を談めた。2）チャコール添加リピョド 一ル注入症例では、術中直視下にリンバ節を確認する ことが可能となり、完全なリンバ節郭清が可能であっ た。 
314 食道癌における腹腔内リンバ節転移

熊本大学医学部第二外科

蓮尾友伸,三隅厚信，近藤浩幸，原田和則，臬正治， 菂田将臣, 菊池暢之, 那須二郎, 栗崎 貴, 赤木正信

食道癌は発生部位の如何に拘らずしばしば腹部リンパ 節転移を来すことが多い。そこで、昭和 50 年1月から昭 和 61 年 12 月までの食道癌切除例 127 例を対象として、 食道癌における腹部リンハ節転移について検索し、外科 治療上における腹部リンバ節郭清の意義について㭘討を 行った。

リンパ節転移陽性率は 53.1\%(68/127)であり、転移部 位別では䋛隔内リンバ節転移陽性率が $54.4 \%$, 腹部リンパ

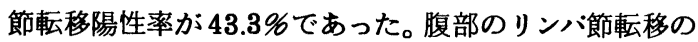
内訳は 1 番: $26.8 \%, 2$ 番: $21.3 \%, 3$ 番: $15.0 \%, 7$ 番: $18.1 \%$ 、郭清例は少ないが 8 番: $25.0 \%, 9$ 番: $50.0 \%$ であった。

腹部リンバ節転移率について病巣の部位、肉眼型、大き さ、外膜浸潤の程度、分化度、術前照射の有無などの因 子別に検討した。腹部リンバ節転移率は、病巣の部位別 では $\mathrm{Ei}: 55.6 \%, \mathrm{Ea}: 41.7 \%$ と胸部下部・腹部食道癌で高 くなっているが、Iu,Imの胸部上中部食道癌であそれぞれ $18.8 \%, 25.0 \%$ あった。肉眼型別では隆起型が $41.7 \%$ ともっとも高く、以下潰湯型 $31.7 \%$, 表層型 $21.4 \%$ の順 であった。病巣の大きさでは腫瘍長径 $4 \mathrm{~cm}$ 末満の比較的 小さな㾞であっても 1 番、2 番、3 番はもとより、7番リン 八節にも13.3\%の転移率を示していた。外膜浸潤では、 その程度が強くなるにつれて転移率が高くなっているが $a_{0}$ の症例でも 33.3\%の転移率であった。さらに7番リン ハ節への転移をみると浸閏度の低い $a_{0}, a_{1}$ でも、それぞれ $15.6 \%, 22.7 \%$ と高い転移率を示していた。分化度別、 術前照射の有無別では転移率に一定の傾向はみられなか った。

治癒切除例を対象として、その予後をリンバ節転移の 面から検討した。腹部リンバ節転移の有無別でみると、そ の両者間の予後には殆ど差は認められなかった。さらに、 縦隔リンバ節転移の有無と腹部リンバ節転移の有無との 組合せにより 4 群に分けて検討した。緃隔・腹部のいずれ のリンバ節にも転移がない群の 5 年生存率は $59.3 \%$ とそ の予後は良好であるが、いずれのリンバ節にも転移が陽 性の群では 0\%と予後不良であった。また、腹部リンバ節 のみに転移陽性の群のほうが、縦隔リンバ節のみに転移 陽性の群に比べて有意に予後良好であった。

まとめ:(1)食道癌切除症例の腹部リンパ節転移陽性率 は 43.3\%(55/127)であった。(2その内訳は 1 番 $26.8 \%, 2$ 番 $21.3 \%, 3$ 番 $15.0 \%, 7$ 番 $18.1 \%$ であり、8番, 9 番に あそれそれ 5 例 , 6例の転移陽性例がみられた。(3)緃隔りン 八節転移陰性で腹部リンパ節転移陽性症例の 5 年生存率 は、綐隔リンバ節晹性で腹部リンバ節陰性症例のそれに比 べて良好であった。したがって、縦隔内に転移がなくても 腹部リンバ節の充分な郭清が必要である。
315 胸部食道癌における腹部大動脈周囲リン 八節転移例の検討

東京医科歯科大学第 1 外科

山崎繁, 吉野邦英, 滝口透, 河野辰幸,

下重勝雄, 鈴木知行, 山際明暢, 遠藤光夫

食道の下方向リンパ流を, 解剖・経内視鏡的

1 ymphoscint igraphy よ゙から検討し，その主経路 が左胃動脈采に沿って腹腔動脈周囲リンパ節 ( 9 番), 腹部大動脈周囲リンパ節（１６番）へ向5ものであり, さらにんくつかの短絡路が存在することにつんては報 告してをた。今回は胸部食道痛における手術時 16 番 転移例（以下手術例），および再発時 16 番転移例

(以下再発例) につんて検討し, 治療方斜につんても 言及したん。

対象例は, 手術例 7 例, 再発例 5 例である。

性別は手術例飞女性 1 例をみる以外, 全例男性であ つた。主占居部位は，I u の症例はなく，Im 4 例， E i 8 例であったが, 1 部位に占居する症例は, Im 2 例, $\mathrm{E}_{\mathrm{i}} 2$ 例であり, 2 部位・3 部位に占居する症 例が 6 例・ 2 例と全体の $66.7 \%$ 占めた。 $\mathrm{E}$ i 例で は E i Ea 3 例, Ei EaC 1 例と肛門側入進展している ものが多く，全体の腫場長径は平均 $7.2 \mathrm{~cm}$ でった。 腫湯の肉眼型は, 潰湯型 10 例, 表在隆起型 2 例で, その境界の性状は不明瞭型・中間型 11 例, 明瞭型 1 例である。組織型をみると，高分化型 1 例，中分化型 6 例，低分化型 5 例であり，脈管侵襲はリンパ管侵襲 ・血管侵襲共に全例陽性であった。同時に切除された 胃噴門部の組織学的検索では，直接 $\mathrm{E}-\mathrm{G} \mathrm{j}$ を越え浸潤 したもの 1 例，胃壁内浸潤单を認めたもの 6 例と強い リンパ行性進展を示唆した。腹部リンパ節転移につん てみると，手術例では，1，2 番〜3 番〜 7 番〜 9 番 〜 16 番と連続して転移のみられる例が压とんどであ り，転移率は，1番 $85.7 \% ， 2$ 番 $85.7 \% ， 3$ 番 $71.4 \%, 7$ 番 $71.4 \%$ ，9.番 $57.1 \%$ と非常に高く, リンパ節転移個数も平均 9.1 個と多かった。再発例で も同様であるが，1・2 番陰性例，9番のみ陽性例が それぞれ1例ずつみられ，術中のより注意深い検索の 必要性が示唆される。

現在，教室では，I m以下の食道瘦に対して積極的 に郭清する方針としているが，その適応については検 討中である。腹部リンパ節転移の診断はretrospect ive には满足すべを成績は得られておらず，エコー - C T の術前診断に加え, 最近では超音波内視鏡も導 入している。また、16 番転移陽性例の治療は, 化学 療法を中心とした集学的治療が望をれ, Subrenal Capsule Assayによる抗癌剤感受性試験を応用しつ つある。 
胸部食道密における術前シスプラチン 療法

\section{熊本大学第 1 外科}

田平洋一，大熊利忠，萩原直樹，鳥越舫継，

岡村健二，近藤圭一郎，堀地義弘，宮内好正

昭和58年 1 月から昭和 62 年 9 月まで当科で経験した 胸部食道癌切除例は68例で、このうち67例にシスプラ チンを中心とした化学橑法（以下本㞠法）を術前術後 にわたり施行した。このうち主病栄の組維学的効果度

（大星・下里分類に隼ずる）が判明している59例を対 象として、主に本療法の術前施行による主病晕の組織 学的効果度と予後および組織学的進行度との関係、本 療法の効果率と主病巣の壁深達度および組織学的分化 度との関係，術後再発例の検討などを行った。対象59 例の組織学的進行度はst.0:3 例, st. I : 6 例, st. II

2 例, st. III : 17例, st. N : 31例であり、 6 例に $27 \sim 50$ Gyの術前照射が併用された。主病栄の組織学的分化度 は、低分化型扁平上皮虚11例，中分化型泉平上皮意 19 例，高分化型扁平上皮密29例であった。本療法による 主病晕の組織学的効果度は、Grade $0: 6$ 例, Grade I : 25例, Grade II $A$ : 22例, Grade II $:$ :6例, Grade III：0 例, Grade IV: 0 例であり、Grade I の 2 例， Grade II A 3 例, Grade II B 1 例が術前照射併用 例であった。Grade 別の予後を検討すると、Grade 0 で 2 年以上生存例は認められず、Grade II 中 3 例は 2 年 6 ケ月以上の生存例であり、Grade の高 いものに長期生存例が琶められる傾向にあった。 Grade と主病巣の組織学的壁深䢖度 (a) の咸係をみる と、Grade II: 以上の勃果度が琶められた 6 例中 5 例 が $a_{1}$ 以下であり、逆に $a_{2}$ 以上の症例 36 例中Grade II 以上のものは 1 例にすぎなかった。Grade II

症例数の占める割合（\%) を効果率とし、a因子別に 検討すると、 $a_{0}: 71 \cdot 4 \%, a_{1}: 55 \cdot 5 \%, a_{2}: 40 \cdot 0 \%$,

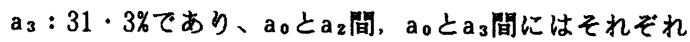
有意差が認められ、 $\mathrm{a}$ 。の効果度が有意に高かった。主 病巣の分化度別にみた効果率は、低分化型 $9.1 \%$, 中分 化型 $47.4 \%$ ，高分化型62.1\% であり、低分化型と中分 化型との間，低分化型と高分化型との間にそれぞれ有 意差が認められた。組織学的根治度 (c)が c II 以上で 再発が認められた症例は 6 例であり、再発率は $10.2 \%$ であった。Grade 0:1 例, Grade I : 1 例，Grade II : 4 例であり、必ずしも効果度との相関は認められず 、しかも全例に術後本㞠法が施行されていた。再発形 式はリンバ節再発 4 例 (No.102 1 例, No.104のへ 3 例, No.106 1例) 、肝再発 1 例，肺再発 1 例であった。 充分なリンバ節郭清, 後㞠法の充実および抗癌剂感受 性試験の導入が必要と考えられた。
317

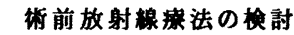

鹿児島大学第一外科

榎本稳美 草野力 夏越祥次 牟礼洋 吉中平次 馬堨政道 福元俊孝島津久明

目的:胸部食道癌に对して教室では腫病辰径 $7 \mathrm{~cm}$ 以上 あるいはA $A_{3}$ の㩆われる症例に対して、的边より上 下 $3 \mathrm{~cm}$ 、幅 $5 \mathrm{~cm}$ の籍曲で、40〜50Gyの得前照射を施行して

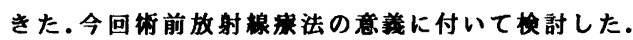

方法:1972〜1986年までの胸部食道覻切除例のうち。 街前照射非施行群 222例、照射群53例を対象として梌討 した.1)切除㯲本における癌細胸の主たる在存部位が、

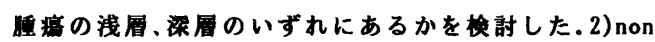
viable cell,度痕、猿死紧の存在部位を照射前の深達 度とし、viable cellを㯵かでも㒛める層を照射後の深 達度とし、照射前後の深達度の改善度を梌討した。3)照

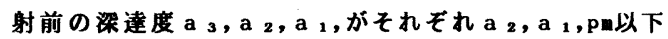
に改善したものを $a_{1+}$ ) 改善群、改善しなかったものを $\mathrm{a}$ ( ) 非改善群、照射前深達度がpロ以下で照射後 $\mathrm{s}$ 以以下 に改善したものをa(，改善群、改善しなかったものを a ( - 非改善群とし、非照射群の予後と比较した。4)照 射群の転移リンパ節に対するEf、占居部位别リンパ節 転移状況、再発率を非照射群のそれと比較梌討した。

成鈢：1）非照射群の5生事 $28 \%$ 、照射群の5生事38で有

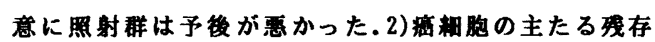
部位はEf1で、s層6\%、Pn首39\%、全首55\%、Ef2で、s層 26\% 、P圈41\%、全首33\%で我存部位はEfによらず、多蚑に湾 っていた.Ef3は3例 (6\%)であった。3)深達度の改善し たものは53例中19例 (36\%)で、そのうちEf1 47\%,Ef 2,3 53\%であった.4) a(た)改善群の2生事 $12 \% 、 3$ 生事0\%、aは ，非改善群の3生事 $14 \%$ 、非照射群の $a_{1+1}$ 群の3生事 $21 \%$ 、 照射群の a 1-）群は殆どが非改善群で占められ、5生率 6 ※、非照射群のa(一)群の5生事43\%で、照射群は非照射群 に比して予後が惠かった.さらにStage别にわけ、予後 を比較したが同様であった。特にStage1において、琞射 群の5生事 10\%、非照射群の5生率43\%と、有意に照射群は 予後が惠かった.5)転移リンパ節でEf 2 以上の効果を琶 めた部位は、中、下䋛隔リンパ節で、照射群の中、下样隔 リンパ節の転移事は非照射群に比して低下していた。 また、照射群の再発事47\%、非照射群の再発事33\%で照射 群の再発事の方が高かった。

結果:1)Ef 2といえども癌絧胞の残存部位は浅層から 深層まで多岐に及んだ.2)深達度の改善はEfと一致せ ず、深達度が改善しても予後が良くなるとは言えない。 3)中、下椾际移リンパ節にEf 2 以上の効果を琶め、同 部位のリンパ節転移事は非照射群に比し低下したが、 再発率は照射群が高かった.4)切除可能な胸部食道癌 に対する沜前照射の意義は少ないと考える。 
318 食道癌術前合併療法としての温熱療法の

検討

\section{千葉大学医学部第二外科}

花岡明宏, 小野田昌一, 奥山和明, 唐司則之,

山本義一, 小出義雄, 巴 雅弘, 松原宏昌, 破野可一

食道癌に対する新たな集学的治療の一つとして温熱 療法を導入し，その有用性につんて検討した。1982年 上り 1986年まての間に術前合併療法に温熱療法を導入 した症例は32例であり，19例は照射十温熱療法，13例 は照射十免疫化学療法十温熱療法を行った。食道加温 には深部到達性の良い1 $3.56 \mathrm{MHz}$ の $\mathrm{RF}$ 波を用い, 電 極を癌腫まて経口的に㨂入する内腔電極法と, 癌腫を 腹背方向よりはさむ体外電極法とを用いた。温熱療法 は30分/回, 2 回/週（計 4〜5回）, 照射は2 $23 \mathrm{~Gy} /$ 回 (計 $49 \leqq \mathrm{TDF} \leqq 62)$, 化学療法は BLM $10 \mathrm{mg}$ 回 (計 $100 \mathrm{mg}$ ), またはCDDP $50 \mathrm{mg} /$ 回 (計 $100 \sim 150 \mathrm{mg}$ ), 免 疫療法はPSK（3.0 g/日）をたは Bes tatin（30 mg/日） を入院翌日より手術前日まで投与した。手術は合併療 法終了後10〜14日にて行った。

合併療法別反みた組織学的効果は, 照射単独で $\mathrm{Ef}_{3}$ $17.6 \%$, 照射十温熱療法で $\mathrm{Ef}_{3} 26.3 \%$ であり，また照 射十免疫化学療法では $\mathrm{Ef}_{3} 24.6 \%$, 照射十免疫化学療 法十温熱療法では $\mathrm{Ef}_{3} 46.1 \%$ となっており, 温熱療法 併用の効果が認められた。また温熱療法併用により $\mathrm{Ef}_{3}$ となった症例の予後は, 従来の合併療法による $\mathrm{Ef}_{3}$ 之同様に良好であった。更に原発巣の所見別に組 織学的効果を検討すると, 従来の合併療法に比べX線 型では鋸歯型, らせん型, ロート型などの局所深達型 VEf $\mathrm{f}_{3}$ が多く, また深達度ても $\mathrm{A}_{2} \mathrm{~A}_{3} \mathrm{KE \textrm {f } _ { 3 }}$ が多くみ られた。次に頸, 胸, 腹の三領域リンパ節郭清を行っ た症例につんて遠隔リンバ節 $\left(n_{3} n_{4}\right.$ 群) 転移率につん て検討すると, 照射十温熱療法 (18例) て $50.0 \%$, 照射 十免疫化学療法十温熱療法 (10例) て50.0\%, 照射十免 疫化学療法 (15例) て53.3\%टなっており, いずれの 治療群間で転移率にほとんど差が認められなかった。 また再発形式では局所再発を $\mathrm{a}_{2} \mathrm{a}_{3}$ 症例で検討すると, 照射単独で 4 例中 2 例 $(50.0 \%)$, 照射十免度化学療 法13例中 3 例 (23.1\%) であるが, 温熱療法併用群では 15例中 1 例のみと，局所再発率の低下がみられた。しか しリンパ節再発, 臟器再発, 播種性再発につんてみる と, 免疫化学療法を伴わない照射十温熱療法群にやや 再発率が高い傾向にあった。

以上より温熱療法の併用はX線型ては鋸菌型, らせ ん型, 口ート型, 梁達度ては $\mathrm{A}_{2} \mathrm{~A}_{3}$ の局所進行例に対 しても有用でり,ひいては局所再発の減少から治療 成績の向上飞役立つものと思われる。しかし遠隔転移 再発に対する影響がまだ十分に解明されていない現在, その施行にあたっては免疫化学療法の併用が必要之思 われる。
319 全道再建術における吻合器及び吸収性 ステーブルの使用経験

\section{日本大学第 III 外科}

佐藤博信。田中隆、河口忠彦、村山公、

須田清美、鈴木武樹、大掫善久、坂部孝

昭和 53 年上り当教室におらて各種消化管の吻合に 際して吻合器を使用し始め現在までに 4000 例になる。 始めはン倳製の万能型消化管吻合器 (SPTU)を使用し ていたが、術野の狭い所や届曲した所で操作のより容 易な管曲軸型消化管吻合器（中山式）を使用した。 しかし本器はステーブルの塤、内筒刃の交換、ワッ

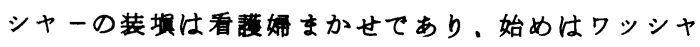
一の未烄のわの、円筒刃の切れの悪いわのなどのト ラブルがあり。またステーブルの脱落を心配しながら 常に使用していた。しかし昭和 60 年 6 月からは新し く開発されたディスポーザブルEEAを使用するとと とし、今までのトラブルわ全くなく現在に至っている。 なお本器わ㨁型と䇰曲型の 2 種類があるが前記の理由 でCurved Disposable EEAを使用するとととなり現在 まで 8 列になる。

食道再建に際しては前述の如く各種吻合器を使用し ているがそのらちわけは、咽頭周吻合術に9例、食道 胃吻合術飞81例、食道回結腸吻合術(食道結腸吻合 術1例を含む)飞4例、食道染腸吻合術に3 例を使用 した。このうち咽頭周吻合では1例、食道男吻合では 7 例に minor leak 認め。再手術を要する major leakは食道周吻合のらち2例（2名）飞認めた。 しかし以前の手程ら吻合における食道再建時の程合不 全と比較するとその発生率は減少している。

また吸収性ステーブルは吻合器抻入孔の閉鎖に利用 しているが食道再建時には12例について使用した。 現在までのところこのステーブルに起因した程合不全 や出血などの合併症は認められず良好な結果を得てい る。

以上より食道再建時における吻合器の利用は有用で あると考える。 
320 的治療について

術後消化管吻合部狭窄にたいする内視鏡

\section{順天堂大学第 1 外科}

林田康男, 清水忠典, 溝㴊 昇, 劉 星漢, 中津基貴, 塩崎哲三, 大坊昌史, 巾 尊宣, 渡部洋三, 湘原 宣

【目的】手術後にみられる吻合部狭窄は繾合不全の結 果として発症するてとが多いか，原因不明のてともお る。本症は患者にとって極めて苦痛なものであり, 治 療に関しては, 種々の方法が用いられている。

今回, ての吻合部狭窄にたいして内視鏡的治療を試み, 良好な成績といくつかの知見をえたので報告する。

【症例および方法】検討症例は吻合部狭窄を示した食 道癌 8 例, 胃癌 8 例, その他 2 例の計18例である。再 建術式は頸部食道・胃管吻合術 8 例, 食道・空腸吻合 術 8 例，その他 2 例である。狭窄の原因として繾合不 全が14例, $77.8 \%$ を占めた。

内視鏡的治療に用いた機種はオリンパス GIF-P 10 で, 高周波電気入ス, Celestine tube (英国製), 拡張 バルーンを同時に用いた。

【結果】高周波電気メスによる切開は13例, 43回施行 され, Celestine tube, 拡張バルーンは 5 例, 25回施 行された。

吻合部狭窄にたいする効果は通常の家庭での食事摄 取に不自由がみられず, 患者の愁訴むみられない状態 を治癒と判定した。

治療例は16例, 88.9\%であり, 治療継続中は 2 例, $11.1 \%$ あ゙あ。

治癒例にたいする治療内容をみると，高周波切開の みによるもの 13 例, 拡張術のみによるもの 2 例, 両者 併用は 3 例であった。

治療処置回数は高周波では $1 \sim 9$ 回 (平均 3.3回), 拡張術では 1 12回 (平均 5 回) であった。

処置回数は治療術式には差はみられず, 狭窄の程度 と比例する傾向にあったが, 高周波切開と拡張術の併 用がより良好であった。

【結語】消化管の吻合部狭窄は繸合不全に基つくくとと が多いため, 繾合不全の程度が高度な例ほど狭窄も高 度であり，治療に抵抗する傾向が強かった。

狭窄にたいする高周波電気入ス, Celestine tube, 拡張バルーンはいずれむ効果が認められたが, 狭窄痗 痕部にたいする的確な切開と拡張術の併用が最も有効 な方法であった。

\section{食道癌術後吻合部狭窄症に対する治療経験}

神戸大学第 2 外科

渡部宜久 松森正之 良原久雄 小山隆司

中村和夫

食道癌術後の吻合部狭窄症は、しばしば経験される合 併症である。今回われわれは、吻合部狭窄の発生頻度 について、䋖合手技別及び再建䐵器別（食道一胃管・ 空腸・結腸）に検討するとともに、治療法については 初期に実施していた手術療法と、現在行なっているバ ルーン拡張術の 2 法を比較検討した。

対象症例は、昭和50年以降当科にて手術した食道癌症 例 128 例である。乙の間治療を要する術後吻合部狭窄 は 9 例 (7\%) にみられた。術後狭窄症状出現までの 期間は、 2 ケ月から 2 年 6 ケ月の間で平均 10.4 ケ月て おり、繾合不全に続発した症例は 1 例むなかった。再 建䑏器別に見ると、食道一胃管吻合が 7 例、食道一空 腸吻合が 1 例であった。繾合手技別にみると、初期に行 なっていたALBERT-LEMBERT縫合は27例中 4 例 (15\%) と最も頻度が高く、層々吻合では 90 例中 4 例 $(4.4 \%) 、 E E A を$ 用いた機械吻合では 8 例中 1 例 （13\%）に合併している。狭窄に対する治療法は、昭和 50年から57年までの前半は手術的に狭窄部の繸切り横 縫い法を行ない、吻合部の直徍は平均で術前の 5.7 = から術後の 17.5 - へと改善し、全例満足のいく結果を 得た。昭和58年以降は、Micro Vasive 社製のRigiflex Dilator [直径15 =又は20m]を用いたバルーンによる拡 張術を開始した。本法は入院の必要がなく実施が容易 である点で優れており、平均施行回数は 2 回（2４ 週間隔)で、吻合部の狭窄は術前の平均 $6.7=$ から術後 13.3 - へと拡大し、手術療法と比較しても遜色のない 結果を得た。

\section{(まとめ)}

食道癌術後吻合部狭窄症の 9 例位対し手術療法 (5例) とバルーンによる拡張法 (4 例)を施行しいずれも満足 いく結果が得られたが、バルーンによる拡張法は外来 であ行なえるため、今後吻合部狭窄症に対するおすな 治療法として使用していきたいと考えている。 
岐皁大学第 1 外科

矢野好弘，松波英寿，味元宏道，小池茂文，尾関 豊 日野晃紹, 林 勝知, 鬼束惊義, 広瀬光男

食道の誐痕性狭窄に対して、われわれはRigiflex Soft Tip Diator(Microvasive社製)とCelestin Diator(Medoc社製)を用いブジーをおてない良好な効果を得ている ので報告する。

<対象と方法 $>$

岐皁大学第 1 外科で過去 1 年 6 ケ月の間に食道ブジー を施行した症例は12例でそのうちわけは、食道離断術後 2 例、胃全摘術後 1 例、食道癌胸腔内吻合術後 2 例、食 道癌頸部吻合術後 3 例、食道静脈瘤硬化療法後 4 例である。

いずれの症例についてもRigiflex Soft Tip Diator(径 $20 \mathrm{~mm})$ を用いた。Diatorの挿入は、透視下で先端部の方 向を確認しながら進めることにより狭窄部を越えること が可能で、内視鏡下でのガイドワイヤー㨂入を要する症 例はなかった。Dilatorのバルーン内圧は40mmHg まで とし、いずれの場合も濃度を下げた造影剤をバルーン内 に注入し狭窄部位の拡張状態を観察した。拡張術は 1 回 に約10分間おてない、硬化療法後狭窄については週 1 回 計 5 8 回施行した。その他の症例では週 2 回 4 6 週 施行した。尚、胸腔内吻合の 1 例ではそれ以後も週 1 回 の拡張をつづけており、頸部吻合の 3 例ではいずれむ Celestin Dilatorによる拡張を追加した。

<効果>

硬化療法後の 4 例については、いずれも 2 ～ 3 回の拡 張術により症状の著明な改善をみた。食道離断術後、胃 全摘術後、胸腔内吻合術後の各症例についても固型物の 摄取が充分に可能となり良好な効果を得られた。頸部吻 合術後例では、いずれもバルーンによる拡張では良好な 効果を得ることができず、Celestin Dilatorを用いた。 Celestin Dilatorは棒状、階段状の器具で、加熱により 自在に曲げることができる。われわれは頸部に狭窄があ る場合のみに使用しているが、2 3 回でとに段階を上 げ太い部分を挿入するととで症状の改善を得ることがで きた。

$<$ 結論 $>$

1. 食道静脈瘤に対する硬化療法施行による合併症の 1 つである食道の瘢痕性狭窄ではバルーンを用いたブジ 一により比較的容易に症状の改善を得ることができた。

2. 頸部吻合術後症例はいずれも minor leakageの治ゆ した後の狭窄であり、バルーンによる拡張では $40 \mathrm{~mm}$ Hgの内压でもバルーンは棒状にふくらまず、Celestin Dilatorによる拡張が必要であった。Celestin Dilator使用による合併症はなく、瘢痕が強度の場合には きわめて有用と思われる。

3.いずれの場合む内視鏡下に施行する必要はなかった。
鹿児島大学第 1 外科, 同: 小巟外科* 喜入厚, 馬場政道, 高松英夫*, 草野力, 榎本捻実, 夏越样次, 春山勝郎, 牟礼洋, 吉中平次, 福元俊孝, 島津久明

[目的]近年、下咽頭頸部食道癌に対する再建術式 として、microsurgeryの進歩に伴い自家空腸遊離移植 が増加している。しかし、移植腸管の形態的、機能的 変化については不明な点が多い。今回、我々はそれら に関して検討すべく、以下の実験を行った。

[対象・方法]体重 $10 \sim 15 \mathrm{~kg}$ の雑種成犬を使用。静 脈麻䣲下に開腹し、Treitzより $40 \mathrm{~cm}$ の部分の空腸を 20 $\mathrm{cm}$ 切離、thiry-vellaの腸墙モデル作成。第 1 群 $(\mathrm{n}=$ $8)$ : 外来自律神経、リンパ管切離群. 一方、対照とし て第 2 群 $(n=8)$ : 外来自律神経、リンパ管温存群。の 2 群に分け、1 時間血行遮断前後の腸管壁の血流を晹 管中央部、腸管膜血管最終結禁点、さらに虚血側 $2 \mathrm{~cm}$ の腸管膜反对側の 3 点 (A, B , C ) において吸入式 $\mathrm{H}_{2}$-gas clearence 法により測定した。さらに $1 \mathrm{w}, 2 \mathrm{w}$ $, 3 w, 4 w$ 後に同様にその変化を調へ、屠殺時、空腸片を 周囲癒着組桟を含めて摘出し里村法により、リンパ管 再生の有無を実体顥微鏡で観察した。さらに両群の血 行遮断前、遮断後 $2 \mathrm{hrs} .3 \mathrm{hrs}$. 1日、3日、5日、1w、2 W、 4 WにおいてA点及びC 点の渴管膜反対側の腸管全 層組鈛を生検、Hematoxylineosine及びHematoxyline 核染色、組糡化学的にはKarnovsky-Roots法によりac-etylcholinesterase(AchE) 染色を施行した。又、晹 管壁にstrain gauge force transducerを綘着、意識 下消化菅運動を24時間連続で記録、経時的にAchE活性 の変化と比較険討した。

[結果] 初回開腹時組織血流量 (⿴囗十 $1 / \mathrm{min} / 100 \mathrm{~g})$ は、 第 1 群で血行遮断前 $\mathrm{A}$ 点 $105.61 \pm 25.61$ 、B 点 $68.34 \pm$

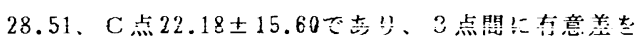

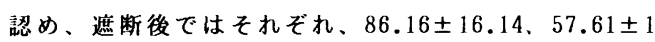
7.89、19.41 16.32 とやや低下した。一方、第 2 群で は遮断前 $\mathrm{A}$ 点 $92.70 \pm 23.59, \mathrm{~B}$ 点 $95.31 \pm 35.03, \mathrm{C}$ 点 19 $.46 \pm 11.52$ と $\mathrm{C}$ 点のみが有意に低下し、遮断後ではそ

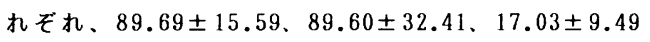
と低下しているが有意差は認めない。里村法によるリ ンパ管の検索では、 $2 w$ 後より血管柄に沿って、再生 が観察された。AchE活性は外来自律神経切離 $2 \mathrm{hrs}$.よ り壁内神経叢の低下が始まり 4 W後で回復の傾向が䚈祭 された。又、3日、5日後で粘膜固有首のcrypt layerに network patternを伴う活性の增強を認めた.以上、遊 離晹管モデルを用い、腸管壁内血流量、リンパ管の再 生、AchE活性の変化及び消化管運動を検討した。 
324 食道再建胃管における用指的幽門括約部 開大法－胃幽門運動機能からみた有用性一

\section{東京医科歯科大学第 1 外科}

河野辰幸, 遠藤光夫, 吉野邦英, 滝口 透 山崎 繁, 下重勝雄, 鈴木知行, 山際明暢

1986 年 3 月以降，われわれは胃による食道再建に際 し，それ以前の前壁 pyloromyec tomy（以下 PM）反かえ 用指的幽門括䄪部開大 (digital dilatation;以下DD) を行っている。DD法で臨床的には全く問題を見ていな いが, 今回, PM施行例之術後胃幽門運動機能面での比 較を行ら，食道再建術におけるDD 法の有用性を検討 した。

対象と方法：対象は昭和 60 年以降，教室において切 除再建を行った食道癌 125 例のらち，胸壁前をたは胸 骨後経路で严全胃による再建を行った食道癌症例で， 再建経路別，幽門処理法別に検討した。評価は， X 線 ビデオ撮影およびアセトアミノフェン法による胃幽門 運動, 排出能の検査, さら反十二指腸胃逆流 (duodenogastric reflux; 以下DGR)反関し, 幽門輪前 $5 \mathrm{~cm}$ での 24 時間 $\mathrm{pH}$ 連続測定を行った。

成 績：1）流動物排出動態：X線ビデオの分析では $120 \% 100 \mathrm{ml}$ バリウム晿下て, PM, DD 両群間の燋下 時間, 幽門輪開大開始時間, 胃排出所要時間に差はな かった。しかし，胸骨後再建例において幽門収縮回数 は $\mathrm{PM}$ 群 $2.7 \pm 1.4$ 回/分 (mean $\pm \mathrm{SD}$, 以下同), $\mathrm{DD}$ 群 $6.5 \pm 1.4$ 回/分 $(\mathrm{p}<0.01)$ とDD群で多かった。また PM群で排出時間の $15.8 \pm 12.1 \%$ が収縮状態であった のに対し, DD群では $35.3 \pm 9.6 \%(\mathrm{p}<0.05)$ と, 100 $\mathrm{ml}$ 排出するまての総幽門収縮時間が長く, 従って, 幽門開大時単位時間当りの排出量は PM群より多かっ た。さらに, 全例においてほほ横隔膜レべル以下の幽 門前庭部で収縮運動が観察されたが, それはD D 群に おいてより強く、また完全な収縮も多く認められた。 しかし順蠕動運動自体は胸骨後再建例において P P 群 $2.9 \pm 0.4$ 回/分, $\mathrm{DD}$ 群 $3.5 \pm 0.6$ 回/分と D D 群に多 らものの, 有意の差は見られず, 胸壁前例でも同様で あった。2）固形物排出能：100 $\mathrm{ml}$ 全䋆試験食におい て, 血中アセトアミノフェン 20 分值を指標として検討 すると, 胸壁前再建 D D 群は $13.8 \pm 10.5 \mu \mathrm{g} / \mathrm{ml}$ とPM 群の $13.1 \pm 9.1 \mu \mathrm{g} / \mathrm{ml}$ と差は無かったが, 胸骨後再建 $\mathrm{DD}$ 群では $16.0 \pm 8.1 \mu \mathrm{g} / \mathrm{ml}$ と胸壁前のものよりやや排 出の良ら傾向が認められた。3）胃管下部の $\mathrm{pH}$ 変動: $\mathrm{PM}$ 群で検査時間の $81 \%$ $1 \% \mathrm{pH} 7$ 以上を示したのに対 し, DD群では平均 $30.5 \%$ と少なかった。

まとめ: 臨床的に PM群とDD群の間に経口恸取状況や食 事中愁訴などに差は見られず, 胃幽門運動ではP M 群 に比べD D 群が本来の運動により近い態度を示し,さ らK, $\mathrm{pH}$ 連続測定から DGR 少ない可能性が示された。 以上より，亜全胃での幽門処理は簡便な用指的開大法 で十分であり，また，胃幽門運動機能温存の面からも 有用な方法と考えられる。

$$
\text { Poor risk 症例に対する食道抜去術の検討 }
$$

神戸大学第二外科

小山隆司・松森正之・渡部宜久 ・ 良原久雄・ 中村和夫

教室で昭和50年以降に経験した食道痹切除例は 110 例で、うち11例 (10\%) に食道抜去術を行った。食道抜 去術となった理由は 3 例が頸部食道癌のためであった か、残る 8 例は心䑏弁膜症や低肺機能など重症の合併 症を有する症例であった。今回我々はPoor risk症例 8 例に対する食道抜去術について検討を加えたので報告 する。

症例の内訳は、男性 3 例、女性 5 例で、年齢は6081 才 (平均71才)、腫瘍占拠部位はIu 2 例、Im 3 例、 Ei 3 例で、腫場長径は $1.5-7.0 \mathrm{~cm}$ (平均 $3.4 \mathrm{~cm}$ )、深達 度はsm 5 例、mp 2 例、a เ1例であった。

基䃈疾患は重症心疾患 3 例 (大動脈弁狭窄 1 例、大 動脈弁閉鎖不全 2 例)、低肺機能 4例、糖尿病十腎機能 不全 1 例であった。

まず、手術時間、出血量は、開胸例でそれぞれ、6。 $32^{\prime} 、 826 m \ell 、$ に対して、非開胸抜去例では、 $3{ }^{\circ} 19^{\prime} 、 370$ $m \ell$ 之後者で有意に少なく、抜去術は侵襲の少ない有利 な術式と考えられた。しかし、食道抜去を行った 8 例 中 5 例で最長 4 年 7 ケ月 (平均 2 年 8 ケ月) の現在再 発の兆候むなく良好な結果を得ているが、残る 3 例は 術後早期に死亡した。乙れら 3 例は大動脈弁狭窄症例

(NYHA III度)、低肺機能例（FEV 1.0 0.59L）、糖尿 病十腎機能不全例 (BUN60mg/de、Creatinine 3.5 mqd $d$ ) と、いずれも重篤な基礎疾患を有する症例で、術後基礎 疾患の増悪が死因になった。また、3例のうち2例に対 しては術前に栄養学的評価も行ったが、ともに表在癌 で摄食障害は軽度であるにもかかわらず、身体学的測 定値及び生化学的検査でも栄養状態は悪く、これが術 後経過に悪影彎を及ぼしたものと考えられた。食道抜 去術は開胸を伴わない手術侵裝の少ない術式であるか、、 このような術式をもつてしても過大侵昤となる症例か あるてとを認識し、このような症例に対しては手術以 外の治療法を考虙するとも必要であるものと考えら れた。今後症例をかさね、術前検查値に栄養学的評価 法などを加味し、Poor risk 症例に対する食道抜去術の 適応を決定したいものと考えている。 


\section{道挿管とBypass術の比較検討}

兵庫医科大学第 1 外科, 同 放射線科*, 大阪第 2 警察病院外科 ${ }^{* *}$

中井謙之, 岡本英三, 富本喜文, 古川一隆, 菱川良夫*，朱 明義**

当教室における過去14年間の食道癌症例は 124 例で, うち切除例は82例 (66\%), 切除不能例は42例 (34\%) であった。切除不能例のうち，狭窄あるいは食道・気 管瘦に対して, 昭和 61 年より内視鏡下人工食道挿管を 6 例に施行し，良好な結果を得ている。今回，昭和60 年以前のBypass術 6 例と経過及び予後について比較 検討した。〈対象と方法〉人工食道群 : 6 例, セレス チン・ダイレーターにて狭窄部をブジー後, Medoc社 製セレスチン・パルジョンチューブ又は, 住友ベーク ライト社製人工食道を用い, オリンパス $\mathrm{P}_{3}, \mathrm{P}_{10}$ の ガイド下に挿管した。Bypass群：6 例, 結腸を用い た胸骨後経路のBypass術を施行した。切除不能原因 は，気管などへの局所浸潤が人工食道群で 4 例（うち 3 例は食道・気管瘦形成), Bypass群で 3 例, 遠隔 転移が人工食道群で 2 例, Bypass群で 3 例であった。 全例に放射線照射か施行されていた。人結果>施行日 から経口摂取までの日数は, 人工食道群の 1 日〜 4 日 (平均 2 日) に比し, Bypass群では 9 日〜47日（平 均17日）之手術の影響及び合併症の為長期を用した。 施行前後の食事摄取の変化は, 人工食道群では, 経口 不能から全弹が 3 例, 流動から全弹が 1 例, 流動から 5 分䋆が 1 例, 経口不能から流動が 1 例であり， Bypass群では，流動から全弹が 4 例, 流動から 5 分 弹が 2 例と両群共良好な結果を得た。人工食道群のう ちの食道・気管㾇症例 3 例では，瘦孔が閉鎖され，食 事掑取む可能となった。合併症としては，人工食道群 で, 大動脈への浸潤による出血 1 例, 胸部痛 3 例, 異 物感 2 例, 食物停滞 1 例, Bypass群で縫合不全 1 例, 腎不全 1 例であった。施行日から退院までの日数は, 人工食道群で 9 日〜 43日 (平均 25 日), Bypass群で 24日～75日（平均46日）と人工食道群の方が早期退院 が可能であった。予後は, 人工食道群が 1 週〜 4 ケ月 (平均 3 ケ月), Bypass群が 1 ケ月〜 5 ケ月（平均 3.3ケ月）と差は認めなかった。〈まとめ>切除不能 食道癌に対し，経口摄取を目的とした内視鏡下人工食 道挿管とBypass術とを比較検討した。内視鏡下人工 食道括管はBypass術に比し手技も比較的簡単で, 全 身状態の悪い症例に対しても施行可能である。Bypass 術と比し, 施行後早期に経口㩒取が可能で，入院期間 も短くてすむ。予後もBypass術と差は認めず，切除 不能食道癌の姑息的治療として十分な効果が得られる と思われる。特に，食道・気管瘻症例には有効である。
福島県立医科大学第一外科

今野修、元木良一、井上寺、西要、

遠藤幸男、三浦和久、木暮道彦、八子直檄、

【諸言】高鮯者の增加、及び他疾患に対する手術成 績の向上とが相まって消化器手術の既往をもつ食道癌 症例を経駿する事が多くなってきた。食道癌手術が比 較的安全に施行出来る樣になってきたとはいえ、てれ らの症例では再建䟦器や再建経路の瀷抧、術後管理の 点で問題が多い。今回は教空で経験したこれらの症例 にっいて検討したので報告する。

【対象】昭和 49 年より 62 年 8 月末までの教室原発性 食道癌切除症例 153 例(切除率77\%)のうち Ce 1 例、Im 4 例、Ei 3 例の計 8 例 $(5.2 \%)$ 点対象とした。

【症例】性別は男性 7例·女性1例で、年圇は 48〜69

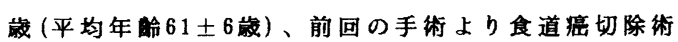
までの期間は最短 1 年 7 月から最長 19 年で、既往手術 はCe例がBillrothII法(胃癌)、Imの4例中 2 例がB-II法

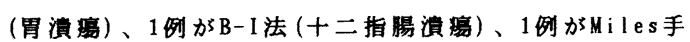

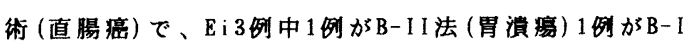
法 (胃湞㬞)、1例が Child手術(膵頭部癌)であった。

【術式と成績】 Ceの1例は頚部にて遊離小腸移植を行 い2 年生存中。ImのB-II法例中 1 例は同時性残胃癌があ り、blunt dissection.残胃摘出·胸骨前結腸つりあけ 非再建、1例は食道垔全摘·胸骨後結腸再建行うも何れ も術後合併症にて直死した。B-I法例は結腸間置し2 2 月生存中。Miles 手術の1例は胃管で再建、7 月生存 中だが骨・肺転移(+)である。Eiの3例中B-II法例は残 胃に偏平上皮癌のskipmetaを証め、食道要全摘·残胃 摘出・胸骨前結腸再建を行ったがLOSから肺合併症で直 死、B-I法例、Child 手術例はとちらち右開胸下部食道 切除・胸腔内食道空腸吻合 (Roux-en Y 及び間置) を施行 したが各々 10 カ、4カ月で失った。

また、これら症例の手術時間及び術中出血量を手術 既往の無い対照群と比較してみると、手術既往例 8 時 間 39 分 \pm 2 時間 26 分 $1247 \pm 809 \mathrm{ml}$ 、対照群7時間 17 分士 1 時間 41 分・1043土603mlであった。

【まとめ】1)教室食道癌切除洌のうち、消化管手術 既往症例は8例 (5.2\%)であった。2)既往手術は、胃切 除術 6 例、Miles手術 1 例、䐗頭十二指腸切除術 1 例で、 胃切除例が多かった。3)手術時間・出血量とも、対照 群と比べ有意の差は認めなかったが、とちらも多くな る傾向を示した。4)手術成績は進行例が多く、術後合 併症による直死畫が $38 \%$ と高率であったが2年生存中の 症例も認める。5)胃切除既往症例 6 例中、2例に副病変 を認めていることょり、術前残胃検索は重要と考えら れた。

以上、消化器手術既往のある食道癌切除症例を検討 し、その問題点について報告する。 
328 および補体価の臨床的意義

\section{大分医科大学第 1 外科}

膳所憲二, 重光祐司，木下忠彦，下田勝広 宮原正樹, 桑原亮彦, 斉藤貴生, 小林迪夫

我々は, 食道癌患者において低栄養, 担癌, 高令な どにより生体防御能が障害され，乙の生体防御能の障 害が術後合併症と密接に関連していることを報告して きた。今回は術後合併症との関連が特に深かった血清 immunoglobul inおよび補体価をとりあげ，その変動 の外科臨床上の意義について検討した。

\section{（方法）}

食道癌 81 例，胃癌56例，胆石症 20 例，若年正常者50 例を対象とした。IgG, IgA, IgM, $\mathrm{C}_{3}, \mathrm{C}_{4}, \mathrm{CH}_{50}$ は レート・ネフロメトリー法で測定した。食道疗患者で は入院時の他に, 放治後, 術後 4 週, 8 週にも測定し た。術後合併症は, 切除またはバイパス手術後 3 ケ月 以内に発症したものに限定し, 感染, 感染を除く䑏器 障害, 繾合不全の 3 つに分類した。いずれも高度, 中 等度, 軽度, 合併症のないものの 4 段階に分け score 化した後, 上記の 6 項目の検査值との間の相関係数を 計算した。

(結果)

食道癌患者のIgG, IgAは, 若年正常者のそれに比し 有意に上昇していた。胃癌患者, 胆石症患者でも軽度 上昇していたが有意ではなかった。IgM は逆に低下 傾向がみられた。食道癌患者の $\mathrm{C}_{3}, \mathrm{C}_{4}$ は, 若年正常者 に比し有意に上昇していた。ただ， $\mathrm{C}_{3}$ は胆石症患者で $\mathrm{C}_{4}$ は胃癌患者でも上昇していたが, 食道癌の上昇より 軽度であった。 $\mathrm{CH}_{50}$ は胃癌患者で有意に上昇していた。 治療との関連をみると IgG, IgA, IgMはいずれも術前 放治，手術によって上昇し特にIgG, IgMの術後 4 週, 8 週の上昇は有意であった。ただ, $\mathrm{C}_{3}, \mathrm{C}_{4}, \mathrm{CH}_{50}$ の変 動は軽微であった。術後合併症と上記 6 項目との関連 をみると, 感染の score とIgAが有意の正の相関を示 した。感染を除く䑏器障害はIgAと有意の正の相関を IgMと有意の負の相関を示した。䋖合不全はいずれと も相関しなかった。また, 術後合併症の総 score と IgA は有意の正の相関を, IgMは有意の負の相関を認 めた。

\section{（まとめ）}

食道癌患者では入院時より IgG, IgA, $\mathrm{C}_{3}, \mathrm{C}_{4}$ の上 昇がみられ，乙れらは手術や放治後に更に上昇する傾 向がみられた。また, 術後合併症のうち, 感染はIgA と臟器障害はIgAおよびIg Mと相関した。その機序に 関しては今後明らかにされねばならないが, 感染や担 癌が関与しているものと思われろ。食道癌外科臨床上 注目すべき現象と考える。
329

食道癌切除術後にみられる気管気管支の虚 血性変化に関する虚血モデルを用いた検討(特に虚血重 症度の判定に関する蛍光内視鏡の応用）

東海大学医学部外科

町村貴郎, 幕内博康, 杉原 隆, 宋 吉男, 花上 仁, 佐々木哲二, 田島知郎, 三富利夫

食道癌の治療成績向上を目的に近年頸部上縦隔の拡 大リンパ節郭清が施行されている。それにともない様 々な程度の気管気管支の虚血性変化が認められるよう になり，てれが術後の重篤な呼吸器系合併症の 1 つと なってきている。今回我々は, 雑種成犬を用いて気管 気管支の虚血モデルを作製し気管支鏡下に虚血気管粘 膜の肉眼所見亡, 蛍光内視鏡下での蛍光パターンとを 観察対比しその予後との関係を検討した。 方法:雑種成犬 $(8 \sim 15 \mathrm{~kg})$ を用いネンブタール $(25 \mathrm{mg} /$ $\mathrm{kg})$ にて全身麻酥下に右開胸を行い輪状軟骨より気管 を左右主気管支まで広範囲に周井結合組織から剥離し， 各部位に流入する小血管を遮断し気管気管支の虚血モ デルを作製した。とのモデルを用い以下の検討を行っ た。1.虚血モデル作製直後に気管支鏡下で虚血気管粘 膜の肉眼所見を観察しその経時的変化および予後の検 討を行った。 $(n=15$ 頭)

2.虚血モデルに $5 \%$ Fluorescein $\mathrm{Na} 1.2 \mathrm{ml} / \mathrm{kg}$ 静注し, 光源に近位紫外線を用いた蛍光内視鏡にて虚血気管粘 膜の蛍光パターンを観察し肉眼所見との対比検討を行 った。

結果:1.虚血モデル作製直後の肉眼所見をその予後より 軽症所見亡重症所見に分類した。軽症所見は，気管粘 膜の発赤, 浮腫, 粘膜下透見血管の拡張を主体とした あので， 4 頭に認められ，全例が所見の消失あるいは, 僅かな痽痕を残して治癒した。一方重症所見は，粘膜 が菲薄化し気管軟骨が透見され，更に粘膜下の透見血 管が暗赤色となり血管内での凝固が起こったと思われ る所見が気管全周に生じたむので10頭に認められた。 そのうち 6 頭は進行性の気管の壊死を生じ肺炎を併発 し死亡し，4頭は巨大な潰瘍を形成したが，症痕治癒 し著明な気管の狭窄を生じた。

2. 蛍光内視鏡下に虚血気管粘膜の観察を行うと, 肉眼 所見で軽症所見との判定した気管粘膜の蛍光パターン は, 虽光出現時間の遅延と共に細顆状あるいは粗大顆 粒状の蛍光パターンを示した。一方重症所見と判定し たものは，残存血管に沿った僅かな線状の蛍光を認め るか, おるいは全く蛍光を認めなかった。 結語: 1. 気管気管支の虚血モデルを用い気管支鏡下での 虚血気管粘膜の肉眼所見と蛍光内視鏡下での蛍光パタ ーンを観察対比し, 虚血性変化の重症度を判定した。 2.蛍光内視鏡下での観察は, 虚血気管の虚血の範用お よび程度の客観的な評価に有用であった。 
千葉大学第 2 外科

豊泉惣一郎, 碓井貞仁, 坂本昭雄, 高石 聡, 山崎一馬, 川村 功, 奥山和明, 小野田昌一, 磯野可一

1977年Maklem らにより呼吸不全の要因として呼 吸筋疲労及び呼吸筋力低下の重要性が唱えられ, 臨床 の場です容易に呼吸筋力測定が可能となってきた。最 近我々は食道癌術前肺機能検査の一環として呼吸筋力 測定を取り入れ，今回は術前栄美状態及びID SEP V 上る呼吸機能訓練の面から呼吸筋力の推移につを検討 すると同時に従来のオートスパイロメーターによる各 肺機能検查値と比較検討した。

【方法】昭和61年 11 月から昭和62年 9 月まての食道癌 術前患者29例を対象とし，のへ 86回の呼吸筋力測定を 施行した。呼吸筋力測定はチェスト社製バイタロパワ 一を用い入院時より手術直前をで数回の検查を施行し た。呼吸筋力の指標は全肺気量位の最大呼気口腔内圧 (ME P) と残気量位の最大吸気口腔内圧 (MI P) で示 した。

【結果】入院時の MEP, M I ¿ 年令についてみると, 70才未満で ME P 84.6土24.6 cm $\mathrm{H}_{2} \mathrm{O}$, M I P 53.0土 $16.6 \mathrm{~cm} \mathrm{H}_{2} \mathrm{Or}$ 対し70才以上では MEP 58.4 土 $22.7 \mathrm{~cm}$ $\mathrm{H}_{2} \mathrm{O}, \mathrm{MIP} 29.4 \pm 13.6 \mathrm{~cm} \mathrm{H}_{2} \mathrm{O}$ ¿70才以上て有意飞 低值を示した。また, 年令と MEP, MIPは各々 P< $0.05, \mathrm{P}<0.001$ 之有意な相関を認め, 呼吸筋力は加 令と共に低下を示した。従来の検査との比較ては MEP, MIP共 K FEV . $_{1.0}, \mathrm{FVC}, \mathrm{PEFR}, \mathrm{MVV}$ の 各指標との間に有意な相関を認めた。入院時を 100 と して最大口腔内圧の推移をみると, 呼吸訓練開始 1 週

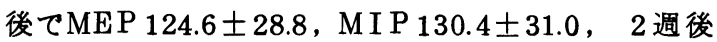
てME P 126.7 土27.4, M I P 142.2土51.6 と良好な呼 吸筋力の増強を認めた。一方, 術前の放射線及び化学 療法のため栄盖状態低下ををたした 3 例の呼吸筋力の 推移をみるとMIPは低下傾向を認めなかったが MEP て $93.5 \pm 17.2(1 \mathrm{w}), 94.3 \pm 6.2(2 \mathrm{w}), 82.8 \pm 13.1$ (3w)，84.6土6.5（4 w) ट筋力の低下を認め, 栄養 低下がMEPに鋭敏に反映された。また, 右開胸開腹 による切除症例中胸壁前再建を行なった15例の術直前 の呼吸筋力之術後肺合併症の検討て忙肺合併症 $\bigoplus$ 群

$(\mathrm{n}=3)$ でMEP $72.8 \pm 8.9 \mathrm{~cm} \mathrm{H}_{2} \mathrm{O}, \mathrm{MIP} 60.9 \pm$ $28.2 \mathrm{~cm} \mathrm{H}_{2} \mathrm{O}$, 肺合併症 $\ominus$ 群 $(\mathrm{n}=12)$ でMEP 85.7 $\pm 24.5 \mathrm{~cm} \mathrm{H}_{2} \mathrm{O}, \mathrm{MIP} 63.6 \pm 22.4 \mathrm{~cm} \mathrm{H}_{2} \mathrm{O}$ といずれる 肺合併症群で低值を示すが有意差は認められなかっ た。

【結語】呼吸筋力測定は病棟で行なえる簡便な検查方 法であるばかりでなく, 術前の栄養状態及び呼吸機能 訓練の効果判定の意味から有用之思われる。
獨協医科大学第二外科

竹岡秀生, 門馬公経, 木多秀彰, 小原靖尋， 宮田秀夫, 門脇 淳, 小暮洋暉, 田島芳雄

目的：食道癌術後の合併症の中で肺合併症は発生頻 度が高く，かつ重箖になりやすい。そこで一期的に食 道癌切除再建術を施行した症例に対し, Swan Ganz力 テーテル ( 以下S CG )による循環動態の測定を行い， 術後肺合併症の発症との関連性について検討した。

対象と方法：(1)症例; 最近 3 年間に教室で一期的切 除再建術を施行した食道癌症例のうち, 術前術後に, S GCによる循環動態を経日的に測定し得た 22 例を対象 とした。そのうち術後肺合併症のみられなかった症例 （A群）は16例である。術後肺合併症のみられた症例 （B群）は 6 例で, 肺合併症の内訳は, 無気肺 3 例, 気管支肺炎 2 例, 胸水 1 例であり, 発症は無気肺がい ずれも術後 5 日目, 気管支肺炎が 5 日目と 10 日目, 胸 水が 8 日目であった。両群の臨床経過と循環動態の経 日的変化との関連性について検討した。

(2)測定及び算出項目 ; 手術前日にS GCを挿入して術後 5 日目までPWP, PA, CV P, CO を測定し, 計算式 によりCI, S V R, PVR, T P R, L V SWI, RV SWI を算出した。

成績：PWPは，A群では術前6.75 $4.49 m \mathrm{Hg}$ で術 後はこれよりやや低值で変動した。B 群では術前 8.10 $\pm 3.61 \mathrm{~mm} \mathrm{Hg}$ で術後 2 日目までははとんど変化はない が，A群よりは高值を示し，3日目には $10.00 \pm 5.83$ $m m \mathrm{Hg}$ とさらに高值となり，4 日目に術前值に回復して いた。P Aは，A群では術前 $13.62 \pm 5.85 \mathrm{~mm} \mathrm{Hg}$ で術後も

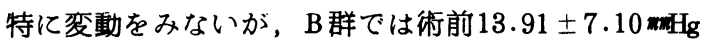
であるのに対し術後 3 日目には20.05 昇を認めた。C V Pは，A群では術前 $5.63 \pm 1.78 \mathrm{~mm} \mathrm{Hg}$ で術後も特に変動をみないが，B群では術前 $5.22 \pm$ $1.22 \mathrm{mmg}$ で術後 3 日目に $7.92 \pm 2.70 \mathrm{~mm} \mathrm{Hg}$ と上昇し た。術後 4 日目までの間に, PWPが $13 m \mathrm{mg}$ 以上, $\mathrm{PAが} 20 m \mathrm{mg}$ 以上, $\mathrm{PAが} 20 m \mathrm{mg}$ 以上, C V Pが $9 m \mathrm{mH}$ 以上の全ての条件を满たした症例は 4 例あったが， A 群にはなかった。その他の項目では，R V S W I が術 後 2〜 3 日目を中心に B 群が $\mathrm{A}$ 群よりやや高值をとっ て変動した。

結語：食道瘦手術後の肺合併症発生の成因について は, 術後 $2 \sim 4$ 日目の循環血液量の堛加が指摘されて いる。我々の今回の検討では術後肺合併症を起した症 例は, 術後 $2 \sim 4$ 日目の循環血液量が過剩であると考 えられ, 肺合併症はこの時期より遅れて発症し, この 時期の循環動態の変化が臨床的な肺合併症の発生の準 備状態と考えられた。 
332 食道癌術後低酸素血症に関する研究 一 $\mathrm{TxA} \mathrm{A}_{2} ・ \mathrm{PGI}_{2}$ の balanceを中心として一

名古屋市立大学 第二外科

谷脇 聡, 片岡 誠, 橋本隆彦, 林 聰一 榊原堅式, 藤井 康, 高木 格, 辻 秀樹 桑原義之, 吳山泰進, 正岡 昭

豊川市民病院 外科

角岡秀彦, 丹羽 傳

食道癌術後早期の呼吸機能低下は, 未だ術後対策とし て重要な課題であり，その病態の解明は十分に為され ていない。以前, 当教室に於て血小板減少との関連に ついての報告をしたが，今回，血小板より放出される セロトニン, トロンボキサン $\mathrm{A}_{2}\left(\mathrm{TxA}_{2}\right)$ 及び, $\mathrm{TXA}_{2}$ 同様アラキドン酸代謝物であり $\mathrm{Tx} \mathrm{A}_{2}$ 沉拮抗する作用 を持つ,プロスタグランジン $\mathrm{I}_{2}\left(\mathrm{PGI}_{2}\right)$ 亿ついて, 術 後の変動を検討したので報告する。

（方法）対象は，食道癌患者12例で，うち頸部食道癌 1 例に食道抜去術が施行され，11例は胸部食道癌で右 開胸による手術が施行された。再建臓器は，全て大等 側形成胃管であり，切除不能でbypass手術のみ施行し た 1 例を含む 2 例が後縦隔胸腔内吻合で, 他は胸骨後 頸部吻合であった。平均年柃は，62.3才で男性10例， 女性 2 例であった。検討した項目は, 呼吸機能, 血小 板, セロトニン, $\mathrm{TxB}_{2}\left(\fallingdotseq \mathrm{T} \times \mathrm{A}_{2}\right), 6$-ketoPGF $1 \alpha$ $\left(\fallingdotseq \mathrm{PGI}_{2}\right)$ であり, 各々術前, 術直後, 術後 1 日目, 2 日目，3 日目に測定をした。

(結果) (1) $100 \% \mathrm{O}_{2}$ 吸入時は $\mathrm{PaO}_{2}$ は, 術直後より低 下を認め術後 2 日目に最低值（術前の $75.1 \%$ ）となり 3 日目に軽度上昇した。一方, 室内空気吸入下 $\mathrm{PaO}_{2}$ は術後 3 日目まで低下を続け術後 3 日目には, 術前の $62.5 \%$ \%なった。

(2)血小板，七ロトニンは術直後より低下をし，血小板 は術後 2 日目に術前值の $44.4 \%$ まで低下し 3 日目に軽 度再上昇した。セロトニンは術後 3 日目まで低下を続 け術後 3 日目に術前值の $37.1 \%$ となった。セロトニン の血小板の値の間には, 正の相関がみられた。

(3) $\mathrm{TxB}_{2}$ は, 術直後に急激な低下を示し術前の $46.8 \%$ と なり，以後術後 3 日目まで徐々に低下を続け，3 日目 亿術前の $13.4 \%$ \%なった。

(4) 6 - ketoPGF $1 \alpha$ は, 術直後一過性の上昇を示し術前 の $393 \%$ に達し, 以後低下し術後 3 日目で術前とほほ 同値となった。

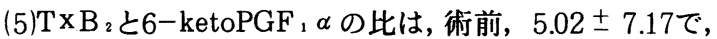
術直後著名に低下し, $0.66 \pm 0.58$ となり,術後 1 日, 2 日 で $1.19 \pm 1.15,1.18 \pm 1.29$ とやや上昇し,術後3日で 0.69 \pm 6.30 と再び低下した。術後の $100 \% \mathrm{O}$ 吸入時Qs/Qtと $\log \left(\mathrm{T}_{\mathrm{xB}} / 6\right.$-ketoPGF $\left.1 \alpha\right)$ との間には正の相関力認められた。 (まとめ) $\mathrm{TxA}$ 2とPGI 2 のbalanceが術後の呼吸機能に 関連している可能性が示唆された。

\section{食道癌術後合併症の検討}

\section{岡山大学第 2 外科}

平井隆二, 三角俊毅, 吉澤順一, 平井俊一,

臼杵尚志，小松原正吉，寺本 滋

食道癌根治手術は開胸, 開腹を要し, しかも高秢者 が多く，大きな侵襲を強いるため，術後合併症の頻度 が高く, 直接死亡例が少なくない。今回，我々は岡山 大学第二外科におりる昭和 37 年より昭和 62 年 5 月まで における食道癌切除再建例73例の術後合併症について 検討したので報告する。切除再建例中，分割手術施行 例は 2 例のみで他は全て一期的手術を施行した。切除 再建術直接死亡例 (以後, 直接死亡例) は10例で, 切 除再建術死亡率 (以後, 直接死亡率) は $13.7 \%$ であっ た。期間を $\mathrm{S} 37 \sim 50$ 年の前期（37例）と S51～62年の 後期 (36例) に分けると，直接死亡率は，前期 $21.6 \%$, 後期 $5.6 \%$ であった。前期では，縫合不全 2 例，肺合 併症 4 例, 循環不全 2 例で, 後期では, 縫合不全 1 例, 肝腎不全 1 例であった。

再建術式別にみた合併症(+)症例と直接死亡率

\begin{tabular}{|c|c|c|c|c|}
\hline 再建術 式 & 症 例 数 & $\begin{array}{l}\text { 合併症(+) } \\
\text { 例 }\end{array}$ & 直接死亡 & 真亡榇 \\
\hline 胸壁前吻 合 & $27(100 \%)$ & $21(77.8 \%)$ & 3 & 11.1 \\
\hline 胸骨後吻 合 & $24(100 \%)$ & $20(83.396)$ & 5 & 20.8 \\
\hline 胸腔内吻合 & $14(100 \%)$ & $6(42.9 \%)$ & 1 & 7.1 \\
\hline
\end{tabular}

術後合併症の内訳と頻度

\begin{tabular}{|c|c|c|c|c|}
\hline \multirow{2}{*}{ 再建術式 } & \multirow{2}{*}{ 拿併症 (十) } & \multicolumn{3}{|c|}{ 合 併 症 の 内 訳 } \\
\hline & & 繾合不全 & 肺合併症 & その他 \\
\hline 胸壁前吻合 & $21(100 \%)$ & $12(57.1 \%)$ & $5(23.8 \%)$ & $8(38.1 \%)$ \\
\hline 胸骨後吻合 & $20(100 \%)$ & $7(35.0 \%)$ & $8(40.0 \%)$ & $9(45.0 \%)$ \\
\hline 胸胿内吻合 & $6(100 \%)$ & $2(33.3 \%)$ & $1(16.7 \%)$ & $3(50.0 \%)$ \\
\hline
\end{tabular}

合併症(+)症例の直接死亡例と内訳

\begin{tabular}{|c|c|c|c|c|c|}
\hline \multirow{2}{*}{ 再建術式 } & \multirow{2}{*}{ 拿併症(+) } & \multirow[b]{2}{*}{ 死何 } & \multicolumn{3}{|c|}{ 合垪症の内訳，直死例数／症例数 (96) } \\
\hline & & & 繾合不全 & 肺合併症 & その他 \\
\hline & 21 & 3 & $2 / 12(16.7)$ & $1 / 5(20.0)$ & $0 / 8$ \\
\hline 胸骨往 & 20 & 5 & $2 / 7(28.6)$ & $2 / 8(25.0)$ & $1 / 9$ \\
\hline 胸腔内吻合 & 6 & 1 & $0 / 2(0)$ & $0 / 1(0)$ & $1 / 3$ \\
\hline
\end{tabular}

（結論）手術直接死亡率は，前期 $21.6 \%$ から後期 5.6 \%と減少したが，乙れは術中・術後管理，栄養管理， 及び手術手技の向上によるものと思われる。合併症を 伴う頻度は，いずれの再建術式でも高いが，特に胸壁 前吻合, 胸骨後吻合で顕著であった。手術直接死亡率 はいずれも高率であったが，特に胸骨後吻合は20.8\% と高かった。合併症 $(+)$ 症例の内訳は, 縫合不全と 肺合併症が最も多く，過去の報告と同様であった。縫 合不全を伴う割合は胸壁前吻合に多いが，直接死亡率 をみると胸骨後吻合が高く，胸骨前吻合の方が安全で ある。また，肺合併症の直接死亡率屯高く，より一層 の合併症対策が必要である。 
食道癌術後の高ビリルビン血症の検討

横浜市大第一外科

安部雅夫, 青山法夫, 野口芳一, 山本裕司, 田村 聡, 赤池 信, 今田敏夫, 天野富薰, 松本昭彦

食道癌術後の高ビリルビン血症は, 他の消化器痹手 術後と比較して発生頻度がきわめて高い。今回我々は 高ビリルビン血症につんて検討を加えたので報告する。 （対象，方法）昭和51年から昭和 62年までに当科て 経監した頸部, 胸部食道癌症例 106 例である。年令, 再建法, 手術侵楽, 術後合併症との関係から検討し, また年代別にす検討を行った。高ビリルビン血症の 定義は血清ビリルビン值が $2.0 \mathrm{mg} / \mathrm{d} \ell$ 以上とした。 （結果）106 例中 55例（51.8\%）に高ビリルビン血 症を認めた。高ビリルビン血症症例の平均年令は 63.9 才であり, 正常例の59.7才に比較してやや高令であっ た。再建術式で検討すると, 胸骨後再建例 $40 \%$ ( 32 ） 79例), 胸壁前再建例 $54 \%$ ( $10 / 22$ 例 $)$, 後縦隔再 建例 $70 \%$ ( $7 / 10$ 例)であった。手術時間は高ビリル ビン血症症例は平均 8 時間 36 分で, 正常例の 7 時間 28分に比較して長かった。出血量は高ビリルビン血 症症例で平均 $1302 \mathrm{~m} \ell て ゙$, 正常例の $1077 \mathrm{~m} \ell に$ 比較して 多かった。術後合併症と高ビリルビン血症の関係をみ ると，合併症発生率は高ビリルビン血症症例で $54.5 \%$, 正常例で $33 \%$ と高ビリルビン血症例で合併症併発率 が高かった。合併症としては, 術後肺炎, 縫合不全が 多く, 高ビリルビン血症症例で, 術後胆震炎が 2 例認 められた。

高ビリルビン血症の発生時期を検討すると, 発生の ピーク值を示す時期は術後 4 日から 7 日目に集中して おりこの時期に $43.6 \%$ めた。また術後 2 週間

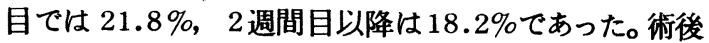
1日目にピークを示す症例子 $10.9 \%$ 認められ,この 症例では間接ビリルビン值が優位であった。高ビリル ビン血症の発現期間は，4日目から7日目にピークを とる症例では平均 6.8 日間であった。前期 5 年間と後 期 5 年間に症例を分けて比較検討すると, 前期の高ビ

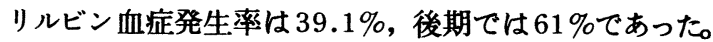
後期症例では手術時間, 出血量ともに郭清の徹底のた めに増加しており手術侵謷が大さくなっている。 (まとめ) (1)食道癌術後の高ビリルビン血症発生率は $51.8 \%$ であった。(2)高令者に発生率が高い傾向にあ った。(3)手術時間, 出血量の増加した手術侵䃞の高い 症例に発生率が高かった。(4)高ビリルビン血症のピー クは 4 日目から 7 日目に多かった。(5)後期 5 年間の症 例に発生率が高く手術侵醅の増加が一つの原因と考え られた。
335 食道癌術後高ビリルビン血症（第二報）： 扗大手術の及ぼす影響について

大阪大学医学部第二外科

辻仲利政、城戸良弘、小川道雄、藤本二郎、 塩崎 均、宮本徳廣、上林純一、松浦成昭、 村田厚夫、森 武貞

目的: 第28回の本学会において食道癌術後 ( 1985) の高ビリルビン血症について検討し報告した。その内 で高ビリルビン血症の発生がT P N 、術前の低栄養指 数、手術侵襲の増加によって増加することを明らかに した。今回扗大リンパ節郭清が施行されるようになっ た1986年以降の症例について調査し、払大手術の及ほ す影響について検討を加えた。

方法：1986〜87年7月の間に手術施行された食道癌 例は31例である。27例の胸部食道癌に対しては、2例 の食道抜去例を除いて預・胸・腹部リンパ節郭清が施 行された。3例の頝部例には両側陑部郭清と食道抜去 術、 1 例の腹部例は左開胸による根治術が施行され た。術後ビリルビン値 2 以上を示したものを高ビリルビ ン血症とし、とくに3.5以上のものをA群、3.5-2 の ものをB群とした。ビリルビン值 2 以下のものをC 群 とした。前回と同様に他の術後合併症を定義した。

成績: 術後高ビリルビン血症の発生頻度は $84 \%$ と 1985 年以前 $(59 \%)$ と比べ上昇していた。5ちA群22例、B 群 4例、C 群5例とA群の割合が多かった。A群7.8土 3.0、B群7.5土4.7 PODと術後 1 週間前後にビリルビ ンの最高値を呈する例が多かった。手術時間はA群496 分、B群478分、C群412分、出血量はA 群 $1,490 \mathrm{ml}$ 、 B群 $1,486 \mathrm{ml} 、 C$ 群996 ml であった。手術時間、出血 量はともにA、B群間で差を認めなかったが、C群に 対して差を認めた。A、B、C群間で患者年令に差は なかった。他の術後合併症（2週以内）の発生をみる とA群では2 例を除いて全例に発生しており、内でも 肺合併症 $77 \%$ 、不整脈32\%、桻合不全 $9 \%$ 、膿汪 $9 \%$ 、 術後出血 $9 \%$ 、MOF $9 \%$ となっていた。2つ以上の 合併症を有していたものが55\%を占めていた。一方B 群では75\%、C群40\%の割合で他の合併症を併発した が、すべて単独発生であった。

結論：払大手術に伴って明らかに術後高ビリルビン 血症の発生は増加していた。とくに肺をはじめとする 他の術後合併症の存在が高ビリルビン血症の程度と発 生に影響を及ぼしていた。また手術侵襲の程度も高ビ リルビン血症の発生に関与していた。このよらに術後 のビリルビン值は侵襲に対する生体の反応の指標之考 えられた。人工呼吸の期間、肺合併症の種類、肝機 能、発熱、白血球数等との相関について検討し報告す る。 
宮崎医科大学第 1 外科

黒木直哉、岩村威志、東 秀史、香月武人

近年癌に対する診断及び治療技術の進歩に伴い同一 個体に複数の癌発生をみる機会が多くなってきた。当 教室において1977年11月から1986年末日までに経験し た食道癌87例中11例 $(12.6 \%)$ に他荿器癌合併が認め られた。第1癌診断後1年以内に診断されたもの（同時 性） 5例、1年以上経過したもの（異時性）6例であっ た。

〈食道癌について> 発症年龄は、50代2例、60代3 例、70代6例と高战者に多く男女比は、9:2で男性が多 かった。食道癌発生部位は、Ce 1例、 Iu5例、 Im 5 例、腫㾮長径は、X線上最小 $1.7 \mathrm{~cm}$ から最大 $10 \mathrm{~cm}$ 、 形態分類は、畽瘤型4例、ラセン型6例、鋸崡型1例で あった。組織型は、中分化腺癌の 1 例を除き全例扁平 上皮癌で、高分化型 4 例、中分化型5例、低分化型 1 例 であった。食道癌切除率は、同時性重複癌症例2例 (4 0\%) 異時性重複癌症例4例（66\%）であった。食道癌 確診後の予後は、前者が、4例が 1 年以内、 1 例が 1 年 7 月で死亡、後者は、 2 例が 1 年以内、 3 例が 1 年以上 2 年以内、1例が 2 年 7 月で死亡であった。

〈他搭器癌について〉 同時性5例中、同一時期に診 断されたものが3例、重複腀器は、術中偶然発見され た胃癌の1例を含む胃2例、肺1例である。他の2例は、 食道癌診断 6 力後死亡、剖検で発見された肺癌と、 やはり5カ月後剖検で発見された臨床症状のない微小 前立腺癌である。異時性例は全て他䑏器癌が先行し た。第1癌は、咽頭、䐅頭、胃、甲状腺、乳腺、堅衁 の各1例を認め耳鼻科領域癌が2例ある以外特徵的傾向 はなかったが、腎衁の移行上皮癌にて堅摘後 1 年 4 カ を経て食道癌が診断された1例は諸家の報告をみても まれな症例といえる。第1癌診断から第2癌診断までの 間隔は、 2 年以内 3 例、 4 年 10 カ 月、9年、14年が各 1 例 であった。第1癌に対する治療は、放射線治療された 咽頭癌以外は全例根治術が施行されていた。

（結語） 同時性、異時性合計した重複澸器は、胃3 例、肺2例、耳奥科領域2例、その他4例であり胃癌は 全て進行癌であった。食道他荿器重複癌の頻度は諸家

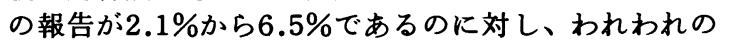
教室では $12.6 \%$ と高率であった。同時性重複症例の方 が異時性に比し食道癌切除率、予後とも悪い傾向が あった。

食道他臓器重複癌は比較的高率に認められ、食道癌 加療に当っては、他臓器癌合併の可能性を念頭におい た慎重な態度が望まれる。
群馬大学第一外科

西田保二, 長町幸雄, 田中 稔, 栗原 透

加藤広行, 櫻井輝久, 小板橋 宏

近年, 診断技術の向上により食道癌と他臓器重複癌 症例も少なからず報告されてきた。今回は教室で食道 と他臓器に重複癌のある症例を調へ検討を加えた結果 を報告する。とくに比較的稀な頸部食道・甲状腺重複 癌の一例を経験したので，合わせて紹介する。

対象は昭和 46 年 1 月より昭和 62 年12月までの16年間 に教室で治療を行った食道癌 107 例であり，てのうち 14例 (13.19) に同時・異時性重複癌を認めた。性別は 男性10例, 女性 4 例であり平均年齡は63.7才で, 40才 以下の症例はなかった。他荗器癌の種類は, 胃 8 例 (57.4\%), 肺, 甲状腺, 乳腺, 腎, 直腸, 前立腺各 1 例 (7.19) で，その中で胃癌が半数を占めた。胃重複 癌 8 例のうち 3 例 (37.5\%) は早期癌であった。同時 性重複癌は 8 例あり, 異時性は 6 例で, 他荗器癌が初 発のものが 5 例を占めたが, 初発癌は全例根治術をう け 7 年以上経過していた。食道癌の主占居部位は Im 6 例, Ei 5 例, $\mathrm{Ce}, \mathrm{Iu}$ 各 1 例で中下部食道に多く, 病期はstage III, IV症例が10例と進行例が多かった。 食道癌に対する治療の内訳は, 切除を行ったのは 5 例 であり，9例の進行例には放射線・化学療法の併用 （放治・化療）を行っている。その予後は, 切除例で は 5 例中 4 例が生存中であるが, 放治・化療の症例は 大部分が 1 年以内に癌死している。

次に, 最近経験した頸部食道・甲状腺重複癌症例を 報告する。症例は54才，女性。主訴は葬下障害と㖽声。 気管, 甲状腺右葉に直接浸潤を認めたため, 喉頭全摘, 甲状腺右葉切除, 食道抜去術を施行したが, 組織学的 検査では, 食道病変は中分化型扁平上皮癌であり, 甲 状腺右葉には小結節を認め乳頭腺癌と診断された。ま た頸部リンパ節には乳頭腺癌の転移を認めた。本症例 は10ケ月後の現在再発むなく生存中である。

まとめ：阿保らは全国集計報告では全食道癌の 3.6 \%に重複癌を認めたとしているが, 我々の教室例の検 討では $13.1 \%$ と高頻度であった。特に重複癌のうち胃 癌が多い事実は胃を食道再建に用いる場合には, 術前 および術後に詳細な検索が必要であると考える。また， 昭和56年全国食道がん登録調査報告によれば，甲状腺 重複癌は全食道重複癌中 $2.6 \%$ であり, 我々の症例は 比較的稀な症例亡思われた。 
一切除例の治療上の問題点について一 横浜市立大学第一外科

青山法夫, 赤池信, 南出純二, 安部雅夫, 田村聡, 山本裕司, 今田敏夫, 天野富㔨, 松本昭彦

神奈川県立がんセンター外科第 1 科

小沢幸宏 , 小泉博義

横浜南共済病院外科・有田英二

1970 年より 1985 年の 16 年間の, 当教室の 食道癌切除例は 202 例である。この中で, 重複癌症 例は 20 例 ( $9.9 \%$ ) であった。男は 15 例，女は 5 例で男女比は 3：1であった。一方, 占居部位は C e 6 ，I u 1，I m 7 ，E i 6 例であった。 第 1 癌と 第 2 缯の発生間隔は, 組織学的に診断された時点より 1 年末满を同時性, 1 年以上を異時性とした。

同時性重複癌は15例（75\%)であり，異時性重 複潭は 5 例 ( $25 \%$ ) であった。

同時性重複癌の他癌発生臓器は, 胃 7 例 ( $46.7 \%$ ) , 甲状腺 4 例 ( $26.7 \%$ ), 結腸 2 例 ( $13.3 \%$ ), 下咽 頭 1 例 ( $6.7 \%)$, 気管 1 例 (6.7\%) であった。

消息不明例（胃） 1 例を除いた 14 例の同時性重複 癌の予後をみると, 生存例 2 例である。 2 例ともC 領 域の早期胃癌合併例で胃部分切除した症例で, 各々術 後 5 年 10 力月, 7 年 11 力月再発なく生存中である 。死亡例 12 例中 4 例（結腸 2 例, 胃 1 例, 気管 1 例 ) $33.3 \%$, 術後合併症のため 3 力月以内に死亡し ている。残りの 8 例は, 1 例 (胃) が 8 力月で他病死 (肝不全)しているが，他の 7 例（甲状腺 4 例，胃 2 例, 不咽頭 1 例) は術後 4 力月～ 3 年 (平均 10.3 力月 )で癌死している。胃癌再発と思われる 1 例を除き， 他はいずれる食道癌死であった。

異時性食道癌 5 例の他癌発生荿器は, 直腸 2 例, 胃 1 例, 舌 1 例, 孚腺 1 例であった。

第一癌が食道であった 2 例とも第 2 癌は直腸で，そ の発生間隔は 2 年 9 力月および 4 年 6 力月であった。 この 2 例の予後は, 第 2 瘦である直腸癌手術後各々 1 0 力月，2 年 5 力月で癌死（直腸）している。いずれ も治瘜切除されていたが，進行㾇であった。

食道癌が第 2 癌であった 3 例の発生間隔は, 胃 2 年 10 力月, 舌 27 年, 乳腺 27 年であった。胃癌は深 達度 $\mathrm{m}$ の早期癌でn。で治癒切除されており再発は認 められなかった。再建 (有茥結腸) 先行で手術を行な い, 4 力月後に食道切除を施行したが, 術後合併症 ( 胆蒦炎）のため 2 カ月後に死亡した。

舌および乳腺は第 2 癌である食道癌手術後各々， 1 年 6 力月および 3 年 6 力月で癌死 (食道) している。

食道と他臓器重複癌症例の切除例は, 3 力月以内の 術後合併症死が $30 \%$ 以上を占め, 同時性に 1 年以内の 短期間の食道癌死が多く，今後の検討を要する。

\section{食道重複癌症例の検討}

秋田大学医学部第 2 外科

下間信彦, 阿保七三郎, 前田清貴,

过 和男, 橋本正治, 四釜俊夫,

山崎泰男, 鎌田収一,

食道の重複癌は, それほど頻度の高いものではない が最近の統計では増加の傾向にある。当教室で 1972 年 6 月から 1987 年 5 月までの 15 年間に取り扱った食 道の重複癌42例について報告する。

同時性重複癌は16例, 食道癌全体の $3.9 \%$ \%ちす へて男性であった。重複癌の発生部位は胃が13例で圧 倒的に多く, 他には肺, 膵臟, 結腸が 1 例ずつ見られ た。15例に手術を行ったが進行胃癌を合併した7例を 除き再建は胃管を用いるととを原則とした。早期胃癌 が小弯及ひ噴門にある場合は小弯噴門切除を行ったの ち胃管を用いて再建したが，乙の術式を施行した症例 で胃癌再発の形式をとったものはなかった。予後は総 じて不良であり 1 年生存率は $30.8 \% ， 2$ 年生存率 $23.1 \%$ で 3 年生存例は今のとてろない。

異時性重複癌は26例， 6.4\%, 乙のうち他癌先行は 男性20例，女性 4例の計24例で，食道癌先行は男性 2 例であった。重複癌の発生部位はやはり胃が15例と最 む多く次は膀胱で 3 例, その他は結腸, 釈腺, 喉頭な どであった。入院後の精査により先行癌の再発が認め られた症例などもおり, 切除率は $77.8 \%$ と当教室の食 道癌全体のそれよりやや低值を示した。術式に関して は再建䑏器として胃管を使用できない胃痹先行例では 主に小腸P結腸による間置術を施行した。その他は胃 管による再建を主に行った。予後は同時性重複癌より やや良好であり， 1 年生存率は $41.7 \% ， 5$ 年生存む 2 例認め, さらに 7 例か現在も follow up 中である。

一般に重複癌の生存率は未だ満足すべきものではな く, 術式及び早期診断について，今後検討を重ねて行 きたいと考える。 


\section{食道:表在癌再発死亡例の検討}

東京女子医大消化器病センター外科
同 消化器放射線科*

鏑木祐二，井手博子，村田洋子，奥島㥶彦， 金原文英，石井洋治，羽生富士夫，山田明義* 【目的】従来の食道愿取り扱い規約で，早期癌や表 在癌に対する細から病理肉眼分類快决められていなか った。しかし1987 年 6 月第 41 回食道疾患研究会におい て，病理肉眼分類検討委員会から表在息の新しい肉眼 分類 (案)が提出され，全国的に臨床検討が行われるこ とになった。そてで我々は本分類案に準じて食道早期 癌，表在癌を分類するにあたり，分類基準ならびに予 後との関保を検討したので報告する。

【対象ならびに方法】1965-1987年 8 月まで当セン ターで切除された表在食道船症例 139 例のうち術前治 療のなされていない 120 例を対象とした。新肉眼分類 案は胃の早期癌肉眼分類に準じて，表在隆起型 $\mathrm{O}-\mathrm{I}$ 型( Ip，I pl，I sub ), 表在平坦型O - II 型( II a, II b， I c ），表在陥凹型O-II型に分けられている。そ てて今回どの様なるのを I 型，II 型，回型にするのが よいか，早期虚はどの肉眼型に相当するかを知るため 飞自験例の表在燩未治療切除例の粘膜面から凹凸の程 度を測定し，深達度との関係をみた。

【結果】粘膜癌 $\mathrm{ep}-\mathrm{mn} 21$ 例中隆起病変は 6 例で粘膜面

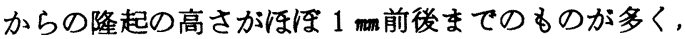

$2 \mathrm{~mm}$ 以上はなかった。平坦病変は 8 例, 陥山病変は浅 レびらん状のものが殆どで，0.5 ma でのものが7例て あった。sm店99例 中隆起病変は，74例 ( > $3 \mathrm{~mm} 27$ 例, 2-3mn 11例， $2 m n$ 前後 18 例， $1 m n$ 前後 16 例， $0.5 m 2$ 例 ), 平坦病変壮 1 例, 陥凹病変は 24 例 $(-0.5 m \pi$ 前後 14 例, $-1 m 3$ 例, $-2.0 \mathrm{~mm} 6$ 例, $-3.0 \mathrm{~mm} 1$ 例 )であった。 今回 $\mathrm{sm}$ 癌のみみられた 2 m以上の隆起を I 群に, epmm癌の含まれる $1 \mathrm{~mm}$ 前後の低隆起 $-0.5 \mathrm{~m}$ の浅い陥凹 病変を II 群に，1 mm以上の焰凹を四群にわけ，梁達度 をみると sm癌は I 群 56/99（56\%）II群33/99（34\%）

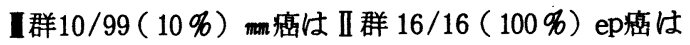
II 群 5/5 (100\%)であった。I群，II群，III群の予後 を Kaplan-M eyer法でみると手術死亡および明らかな 他病死例を除いた 5 年累積生存率は I 群 $55.3 \%$ ，II 群 95.1\%，III群 $43.0 \%$ \% II 群は sm癌を含んでいるるのの 他の表在透に比へ有意に良好て胃の早期密の遠隔成績 に匹敵する。今後さらに症例を重ね検討する必要があ るが，新分類案の $\mathrm{O}-$ II 型を粘膜秥類似の肉眼型 $=$ II 群 (粘膜面からの凹凸が $-0.5 m m<-<2 m$ ) とし, 予 啳のより表在食道船の概念として分類し，治療に刘処 してゆくべを考える。
杏林大学第 2 外科

小野沢君夫。鍋谷欣市, 花岡建夫, 李 思元, 本島悌司, 入村指也, 木村 治, 加来朝王。川 口敏樹, 新井裕二

(はじめに)

早期食道癌の報告が多くなつたが，再発死亡する症 例も少くない.われわれが食道亜全剔術を行なつた食 道表在癌 2 I 例の5ち，4 例が再発死亡している. そてで, 再発死亡例を臨床病理学的に検討した。

(検討䊅果)

術中の胸部腹部リンパ節郭清は、んずれも十分に行 ない, 術後合併療法は，4 例中， $\mathrm{T}$ 字照射 3 例・化 学療法 2 例・免疫療法 2 例である。再発時期は, I0 月〜 2 年 7 月・平均 $\mathrm{I}$ 年 7 月で，再発初発部位は，上 縦隔リンパ節 3 例・肝 I 例である。再発時治療は, 化学痊法・免疫療法を行ない, 上縱隔再発了例には, さらに放射線療法も行なつたが，再発後の生存期間は ，4月〜 I 0月・平均7月に過ぎない。

次に，手術時の臨床病理所見から再発の有無を検討 してみる.

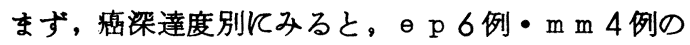
m癌では再発死亡がないのに対し， $\mathrm{g}$ m癌 I I 例では 4 例が再発死亡し，予後は非常にわるい。

$\mathrm{n}(+)$ 表在癌 2 例中 $\mathrm{I}$ 例が早期飞再発死亡し, $\mathrm{n}$

$(\leftrightarrow ・ 1 \mathrm{y} \mathrm{v}(+)$ の 5 例中 I 例が再発死亡しており， 当然のととながら、リンパ節転移・脈管侵襲の有無は ，予後に関与している.

内視鏡型分類では，表在隆起型 3 例中 I 例再発・表 在潰痬型 I 例中 I 例再発・混合型 2 例中 2 例再発之予 後不良なのに対し，表在びらん型Ｉ０例・表在平坦 型 5 例には再発例はない。

病巣の大きさ・占居部位と再発の有無を検討して みたが，有意の関係はなかつた。

(対策)

以上の検討から，食道表在癌のらち術前検查で梁 達度 $8 \mathrm{~m}$ と診断したり。また内視鏡型が表在隆起型・ 表在潰痬型・表在混合型である場合には, 進行癌に 準じたリンパ節郭清と強力な術後合併療法を行なう ことが, 食道表在癌の治療成績を向上させると思は れた。 


\section{癌研究会附属病院外科, 同病理 * 土屋繁裕，松原敏樹，関誠，木下 嶡, 西 満正, 加藤 洋*}

【対象】1960年から1986 年12月までに癌研 外科で切除された胸部食道癌のうち，術前照射施行例 を除いた根治切除例 264 例, 姑息切除例 49 例, 合 計 313 例を対象とした。

【方法】肉眼分類を表在型, 潰痬型, 腫瘤型, びま ん型に分け，また非表在癌についてはその境界の性状 から, 限局型, 中間型, 浸潤型に分け各々の特徵之予 後を比較検討した。壁内転移陽性例および表首拡大型 についても検討を加えた。

【結果】 ○肉眼分類別の割合は, 根治切除例では表 在型 $10 \%$, 潰瘍型 $81 \%$, 腫瘤型 $5 \%$, びまん型 $3 \%$, 限局型 59 \%，中間型 $15 \%$, 浸潤型 15 \%であり，潰福 型および限局型が多かった。姑息切除例でも潰瘍型が $92 \%$ と大部分を占めたが, 限局型 $55 \%$, 中間型 $20 \%$, 浸潤型 $25 \%$ と根治切除例に比し, 中間型, 浸潤型の占める割合が增加する傾向がみられた。また 壁内転移陽性例は $10 \%$ ，表層拡大型は $12 \%$ であった。 ○根治切除例におけるリンパ節転移陽性率は，表在型 $45 \%$, 潰諨型 $76 \%$, 腫瘤型 $38 \%$, 限局型 $73 \%$, 中間型 $74 \%$, 浸潤型 $75 \%$, 表層拡大型 $72 \%$ であ り，表在型，腫瘤型で少ない傾向がみられたが，その 他では差を認めなかった。⑤ 年生存率では, 姑息切 除例に 5 年生存例は認められなかった。根治切除例の うち術後 5 年経過例における 5 年生存率をみると, 表 在型では $83 \%$ と当然のととながら予後良好であった が, 潰瘍型 $30 \%$,腫㿔型 $20 \%$ ，限局型 $31 \%$, 中間 型 $21 \%$ ，浸潤型 $30 \%$ ，表首拡大型 $40 \%$ であり， 大差は認められなかった。また壁内転移陽性例は病理 全割施行例 155 例中の $10 \%$ に認められたが，5年 生存例は 1 例むなく予後不良であった。 $\mathrm{A}_{3}$ 症例だけ に注目してみると, 根治切除例で限局型が $83 \%$ と多 かったのに比し，姑息切除例では限局型は 46 \% と少 なくなり，中間型 $21 \%$ ，浸润型 $35 \%$ と中間型之浸 潤型の占める割合か增加した。

【まとめ】1, 術前非照射胸部食道癌 313 例におい て肉眼分類別にみた特徵と予後を比較検討した。

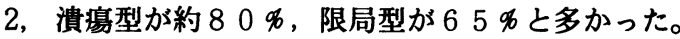
3 , 限局型, 中間型, 浸潤型の 5 年生存率は, 中間型 がやや低いが，大差は認められなかった。また表層拡 大型の 5 年生存率は約 $40 \%$ であり, 癌の表首進展は 予後に影響しないと考えられた。 4 ，壁内転移陽性例 に 5 年生存例は 1 例むなく，予後不良であった。 5 , 姑 息切除例では, 特に $\mathrm{A}_{3}$ 症例で, 中間型, 浸潤型の 占める割合が増加する傾向がみられた。

\section{大阪府立成人病センター外科}

甲 利幸. 古河 洋, 石川 治, 佐々木 洋, 大東弘明, 柴田 高, 福田一郎, 平塚正弘,

龟山雅男, 今岡真義, 岩永 剛

【目的】食道癌の治療成績は他の消化器癌にくらべ不 良である。その理由の 1 つとして, 進行癌の占める割 合が高いととがあげられる。進行癌とくに第 $3(4)$ 群 リンパ節転移陽性例の遠隔成績は極めて不良であるが， なかに少数ながら長期生存がみられる。こうした長期 生存例にはどの様な特徵があるのかを知ることは，今 後の進行癌に対する治療において有益だと考えられる。 そこで, 今回, 3 年以上生存した $\mathrm{n}_{8(4)}(+)$ 胸部食道癌 症例について臨床学的に検討を行った。

【対象および方法】昭和 59 年 8 月までの術後 3 年以上 経過した $\mathrm{C}_{0}$ を除く胸部食道扁平上皮癌根治耐術切除 168 例中, $\mathrm{n}_{8(4)}(+) 52$ 例を対象にした。乙のうち 3 年以上 生存は 11 例 $(21 \%), 3$ 年末满死亡 41 例 ( $79 \%$ )であっ た。てれらを臨床病理所見および合併療法等について 検討し, $\mathrm{n}_{8(4)}(+)$ 症例における 3 年以上生存に関与す る因子について検討を行った。

【結果】 $\mathrm{n}_{8(4)}(+)$ 例における 3 年以上生存例 ( 3 生例) の頻度を各因子別にみると，性別では男 $20 \%$ ，女 $27 \%$ ， と女性でやや高く，年踰別には 60 歳代で $35 \%$ と高かっ た。X線型では腫熘型 $57 \%$ と高く，X線長では $4 \mathrm{~cm}$ 末 满：33\%, 4-6cm: $25 \%, 6-8 \mathrm{~cm}: 19 \%, 8 \mathrm{~cm}$ 以上 : 13 $\%$ と X線長が短いはど 3 生例の頻度は高かった。部位 別では，Iu：0\%，I m:21\%, Ei : $25 \%$ で下部はど 3 生例の頻度が高かった。深達度別には, sm症例（ 2 例）には 3 生例はなく, $\mathrm{mp}: 42 \%, \mathrm{a}_{1}: 12 \%, \mathrm{a}_{2}: 19$ $\%, \mathrm{a}_{8}: 0 \%$ で, mp 症例で頻度が高かった。組織型別 には高分化型：33\%, 中分化型：23\%, 低分化型：0 $\%$ \%, 分化度が高いはど 3 生例の頻度は高かった。転 移リンパ節個数でみると 3 生例はすべて 4 個以内で,

転移リンパ節 5 個以上および壁内転移陽性例には 3 生 例は認められなかった。合併療法の有無別にみると， 合併療法群 $(+)$ 群： $26 \%$ ，(-)群：17\%で合併療法併 用群で 3 生例の頻度は高かった。合併療法のうちでは Adriamycin 投与例 (20 例) が $30 \%$ と高かった。術式で は, 気管全周にわたる上繸隔拡大郭清例 ( 5 例)で 3 生 例は $40 \%$ と高かった。

【結語】 $\mathrm{n}_{3(1)}(+)$ 胸部食道扁平上皮癌でも転移リンパ 節が 4 個以内, $\mathrm{X}$ 線型で腫瘤型，組織型では高分化型 の症例では 3 年以上生存がかなり期待でき，また，ま だ少数例の検討ではあるが, リンパ節郭清を徹底化し， 適切な化学療法を併用するととにより治療成績を向上 させうる可能性があると考えられた。 


\section{秋田大学第 2 外科}

天満和男, 阿保七三郎, 前田清貴,

辻 和男, 渡邊公伸, 鈴木裕之,

近年食道癌の手術成績は向上しつつあるが，他の消 化器癌に比し依然予後は不良であり, リンパ節再発を 来す症例も多い。今回は当科にて胸部食道癌切除術を 施行後, リンパ節再発を来した症例について検討した ので報告する。

対象：1972年より1986年までの15年間に当科で扱っ た胸部食道癌症例は362例, 病巣切除330例, 従って 切除率 $91 \%$ であった。このうちStage III, IV症例が

（76.1\%）を占め, 結局大部分は高度進行癌症例であ った。耐術例のうち組織学的検索が可能な症例につい て, リンパ節転移状況, リンパ節再発状況及びその予 後に関し検討した。

結果：リンハ節転移状況をみると, Iu 症例では頸部 から腹部にかけて広範囲にわたりリンパ節転移が認め られ，特に第 3群リンパ節である№.101，104，1の いずれにおいても15\%以上の高い転移率を示した。Im 症例における頸部リンパ節転移は少ないものの, 胸部、 腹部リンハ節転移が多く，№.1で29\%，№.3，7でも 各々18\%，20\%の転移率であった。Ei 症例においては， 腹部リンパ節転移がさらに優位となり，№.1が53\%， №.3 か41\%，№.7が36\% と極めて高い転移率を示した。 次にリンバ節再発症例では, 再発は№.104 及び No.106のリンパ節に集中し, 特に再発症例の $2 / 3$ 以上が №.104に再発を来していた。さらに食道癌取扱い規約 に定めるリンハ節転移度別生存率ではn(一)群の 5 年生 存率は $33 \%$ であり, $\mathrm{n}(1$ 4) 群の 5 年生存率は各々 7 \%以下で明らかにn(-)群の予後は良好であった。

当科では，術後症例に対し可能な限り再発予防と治 療照射の目的で経口摂取可能となる第10病日前後から， 頸部上維隔を含むT字照射を総量50Gy及60Gy施行し ている。1981年末までに切除した胸部食道癌症例のう ち追跡調查しえた 155 例の 5年生存率はT字照射群19 $\%$, 非照射群 $13 \%$ 之照射群で予後が有意に良好であっ た。又, リンパ節再発症例の生存率をT字照射群之非 照射群とに分けて比較すると, T字照射群か有意に予 後良好であった。

結語：リンハ節再発はNNo.104及びNo.106に集中して おり, 特に再発症例の $2 / 3$ の症例がNo. 104 亿再発を来し, 又, リンパ節転移症例ではその予後は不良である。当 科において術後合併療法として施行している頸部上䅠 隔T字照射法は明らかに予後改善か有効であり, リン 八節再発状况より見て, 今後頸部上縦隔リンハ節, 特 にNo.104，106を外科的に徹底郭清した上でさらに術 後頸部上縦隔T字照射を加えることにより，予後の向 上が一層期待されるものと考えている。
転移と再発について

鹿児島大学第一外科台礼洋榎本稳美草野力 喜入 厚夏越样次馬場政道吉中平次田辺 元 福元俊孝愛甲孝島津久明

下部食道扁平上皮癌といえども、その中心が $\mathrm{Ei} 、 \mathrm{Ea}$ C のいずれに存在するか、判断に苦しむ場合が少な くない。また、胃癌の食道への進展は多く琶めるが、 食道癌の胃への進展例は少ない。一方、胃癌の胸脸内 への転移は少ないが、食道癌では、胸腟、榎部のいす れの部位でもリンパ節転移を琴める。そこで、1973年 〜1986年までに当科で切除された下部食道府平上皮庶 108例を対象とし、主病巣が E-G juntionを越えて目 湖へ進展した29例（A 群）と、E-G junctionを越えて いない79例（B 群）に分けて、リンパ節転移状况、再 発、予後の相違について検討した。

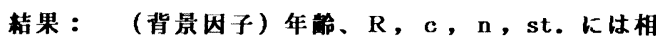
違は琵めないが、A 群では、右開胸開腹例と低分化型

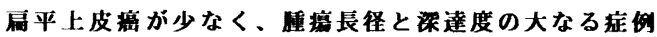
を有意に多く琵めた。

(リンパ節転移状况) 転移柬はA 群で $72 \%$ 、B 群で

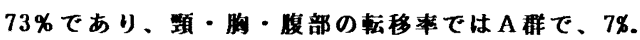
31\%.69\%、B 群で、4\%.49\%、58\%であった。上符隔㹡 移例は全例で15湖 (14\%)、A 群でも4例に瑟めた。

大動的周囲リンパ節転移例は 5 例で、全例 No.7,8,9 のリンパ節に転移を瑟め、その 4例は A 群であった。 E-G junctionを越えて胃湖へ進展する食道度（A 群） といえども、上䋨隔リンパ節への転移を認め、また、 No.7,8,9 リンパ節に転移を琴める場合、大動筸周囲 リンパ節の鄐清を考慮すべきである。

(再発形式) c I 以上の93例を対象とした。再発本 は 36/93例 (39\%)で、A群 9例、B群27湖で、再発本 には相違は認めない。A 群の再発形式は、锿器再発 6 何 (67\%)、リンパ節再発 2例(22\%)、局所再発 1例、吻 合部再発1例であり、B群では、器登13例(50\%)、 リンパ節再発17湖(63\%)、物合部再発1例であった。

A 群では、路器再発が多く、リンバ節再発が少ない項 向を琶めた。なかでも、A 群の器器発は全例肝転移 例であったのに対し、B群の器器再発では肝 3 例、骨 5 例、肺 4 例、脱 1 例、皮虐 1 例となり、A 群では、 門自系の再発、B 群では、大循䛔系の再発形式であっ た。手得から初再発までの期間は A 群で平均 21わ月。 $\mathrm{B}$ 群で11か月、再発から死亡までの期間は $\mathrm{A}$ 群で 2か月 、 $\mathrm{B}$ 群で6⿰月であった。リンパ節再発の多いB 群では 、初再発までの期間が焒い。（まとめ）下部食道局 平上皮癌でE-G Junctionを越える昜合、待後の肝再発 に対する紪重なfollow upと補助法法が重要である。 
346

討

多変量解析法による食道癌予后因子の検

九州大学第 2 外科

松岡秀夫, 矢野和浩, 森 正樹, 桑野博行, 杉町圭蔵

〔はじめに〕食道癌の予后を左右する因子には、病理 組織学的な腫場側の因子に加え、年令、性などの主に 患者側の因子、および、手術操作や術后管理などの主 に手術によって生じてくる因子があり、それらの個々 の因子については多くの検討がなされているが、どの 因子がより強く関与しているかについては未だ一定の 見解を得ていないようである。そてで、われわれは、 食道癌の予后を左右すると考元られる15種類の因子に ついて多変量解析を行ない、より強く予后と相関して いる因子を租み合わせるととによって予后の検討を行 い、今后の食道癌治療に役立てたいと考えた。

〔方法と結果〕対象は、1971 年から1984 年までに 当科で食道癌の手術を行った 126 例中、他病死を除く 123 例である。全症例の術后 2 年目の生存率は、Kaplan \& Meier 法では、35\%であった。一方、予后因子としては、 年令、性、占居部位、腫瘍長径、外膜浸潤、リンパ節 転移、リンパ管侵襲、血管侵襲、粘膜上皮内伸展、

浸潤度 (INF)、核DNA量分布パターン、組織型、組織 学的進行度、根治度、術后合併症、以上15種類の因子 を用い、それらの因子に対して Cox の多変量解析を行 った。その結果、予后と有意に相関している因子は、 根治度 $(P=0.01) 、$ 核DNA 量分布パターン $(P=0.02)$ 、術 后合併症 $(P=0.04)$ の 3つであるととが判明した。更に、 それらの因子を、治撚切除と非治癒切除、I , II 型と III，IV型、術后合併を生じた症例と生じなかった症例 の 2 つに分け、前者を良好な症例、後者を不良な症例 とした。良好な症例は、それそれ55例(43\%)、27例 $(22 \%) 、 65$ 例 $(53 \%)$ で、それらの症例の 2 年生存率は 53、57、42\%と、不良な症例の、19、18、28\%に比心 有意に高い值を示した。次に、3つの因子がすべて良 好な群、1 つの因子のみ不良な群、1 つの因子のみ良 好な群、すべて不良な群の 4 群に分けて検討した。 Kaplan \& Meier 法を用いた 2 年生存率は、それぞれ66、

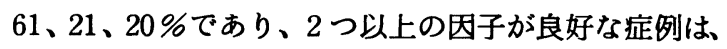
2 つ以上の因子が不良な症例に比べて有意に高い生存 率が得られる事が、generalized Wilcoxon test によ って示された。

[考案]食道癌症例において、核DNA量分布パターン は腫傷側の予后予測因子の内で、現在最も信頼性の高 いものであるととが明らかとなった。根治度や術后合 併症については、今後更に検討され、改善されていく ものと考える。
347 実駼的研究

久留米大学第一外科

松尾喬之、橋本謙、梅谷博史、児玉一成、吉田力、 難波雄一郎、迎徽、平木幹久、武田仁良、掑川暉夫 <目的〉食道・胃境界部領域のリンバ流を解明するこ とは、噴門部癌における合理的郭清を行う上で、極め て意義あるものと考えられる。そこで我々は、癌腫の 局在がリンパの流れに影警を及ぼす可能性を加味し、 家兔 $\mathrm{VX}_{2}$ 睡䶍喷門癌モデルを作成したうえで、食道 胃境界部のリンパ流を検討した。特に上方向経路（下 絴隔リンバ節転移経路）、下方向経路（大動眽周囲り ンバ節経路）、側方向経路（横隔膜）について報告す る。

く方法〉実駼動物は体重 $2 \sim 3 \mathrm{~kg}$ の白色家免を用いた。 ネンブタール $25 \mathrm{mg} / \mathrm{kg}$ 静注にて麻䣷、経内視鏡的に喷 門部および腹部食道にV X 2 腫場浮遊液 $0.5 \mathrm{ml}$ （ $5 \times$ $10^{6}$ 個) を穿刺注入しかかる手技を用いて食道浸洞の 有無によりそれぞれC、C ミ E、E＞Cモデルを作成 した。それぞれのモデルを開胸開腹後、噴門部漿膜下 に微粒子活性炭（CH44）を点墨、肉眼的にリンバ流を 锤察した。屠殺後、下部食道、横隔膜、胃、大動脈、 後腹膜を一体化したC T scan嵄横断面全割標本にて病 理組織学的にCH44および癌腫の広がりについて検討し た。

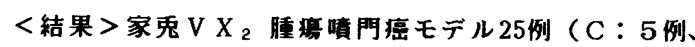
$\mathrm{C} \geqq \mathrm{E}: 15$ 例、C $<\mathrm{E}: 5$ 例）正常10例について検討 を行った。

1)上方向へのリンバ流：正常例およびC 領域癌モデル においては、上方向へのリンバの流れは認めなかった。 $\mathrm{C} \geqq \mathrm{E} 、 \mathrm{E}>\mathrm{C}$ 癌モデルにて腫境口侧食道外膜下にCH

44を点墨すると、食道外膜を上行し食道裂孔を通り下 繾隔リンパ節（110）を黒染後、継隔胸膜を上行する リンバ流が数察された。傍食道上行経路黒染率は正常 : $0 \% 、 C ： 0 \% 、 C \geqq E ： 40 \% 、 E>C ： 60 \%$ あ つた。

2)下方向へのリンバ流：1、左胃動眽経路（左甾動脈 に沿って大動脈周囲に至り、腎動脈分岐部付近にて胸 管に流入する）28/35 例(80\%)に確認された。2、下 横隔動脈経路 (棈隔膜脚上绿を下行し、大動脈周囲に 至る) 10/35 例 (28\%)に確認された。

3) 1、側方向へのリンバ流：癌腫の横隔膜への直接浸 淍なく横隔膜へ流入する経路 $2 / 20$ 例 (10\%) 2、癌腫む しくは転移リンバ節が棈隔膜の一部へ浸洞しさらに㑡 方に至る経路 $3 / 5$ 例(60\%)に確認された。

く結語〉1)食道・胃境界部より上行性りンバ流として 傍食道経路の重要性が破認された。2)同部より直接大

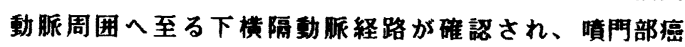
におけるN016リンバ節郭清の重要性が示唆された。 3)横隔膜壁内転移経路が確認された。 
348 について

胃癌における左下横隔動脈流域リンパ節

\section{東京大学第 2 外科}

小西敏郎, 平田 泰, 三山健司, 真船健一,

平石 守, 多田祐輔, 出月康夫

現行の胃癌取扱い規約では，胃癌郭清用リンパ節付 図として，井上論文が引用されているが，左下横隔動 脈流域リンパ節に関しては明瞭な記載がない。同動脈 から分岐する噴門食道枝に沿うリンパ節は(2)左噴門リ ンパ節に分類されているが，同動脈に沿うリンパ節は 4 群として取り扱われている。今回当教室における胃 癌切除例の $\mathrm{n}_{4}(+)$ 症例を検討し, 左下横隔動脈流域リン パ節は, 現在の 4 群リンパ節の中では, 郭清の意義が 極めて高いと考えられるので報告する。

当教室での 1976年以降の胃癌切除例中で $\mathrm{P}_{0} \mathrm{H}_{0} \mathrm{n}_{4}$ (十)症例は 20 例で, 同時期の胃癌切除例の $3.6 \%$ でっ た。これ 520 例の, 胃癌の肉眼的分類は, 0 型 1 例, 2 型 2 例, 3 型 8 例, 4 型 9 例で, 深達度は $\mathrm{sm}$ の早 期胃癌 1 例以外の進行癌では, ps (Hが 16 例と多い。 長径は $5 \mathrm{~cm}$ 以下は 1 例で, $5 \sim 10 \mathrm{~cm} 5$ 例, $10 \mathrm{~cm}$ 以上 14 例と巨大な病巣がほとんどである。切除術式は， 胃全摘術 12 例, 噴門側胃亜全摘 2 例, 幽門側胃亜全摘 6 例で, 胸骨正中切開にて食道を合併切除した食道浸 潤陽性例が 4 例含まれている。これ520 例の 4 群りン パ節の転移陽性部位は，16大動脈周囲リンパ節ー12 例，(15)中結腸動脈周冊リンパ節 -4 例，左下横隔動脈 流域リンパ節 -2 例, 14A 上腸間膜動脈に沿うリン 八節ー 1 例, Virchowリンパ節 1 例であった。これら $\mathrm{n}_{4}(+H$ 例の予後は極めて不良で，14例 $(70 \%)$ が 1 年以 内に死亡している。しかし 5 年以上生存例が 2 例存在 し，共に左下横隔動脈流域リンパ節に転移を有する症 例であった。 1 例はC 後壁の $5.8 \times 5.6 \mathrm{~cm}, \mathrm{ss} r$ の 3 型 胃癌で，他に(2)(3)(11)にンパ節転移を有した。他の 1 例はC 後壁の $6.7 \times 4.5 \mathrm{~cm}, \mathrm{se}$ の 3 型胃癌で, 他に(1) (2)(3)(9)にンパ節転移を認めた。いずれもCの後壁の 3 型胃癌例で, Appleby 法により, 噴門側胃覀全摘術 を施行し, 8 年後および 6 年後の現在再発の徵候なく 健在である。これ 52 例以外の 1 年以上生存例は, 1 年 1 ケ月後死亡の 1 例以外は最近の手術例であるので 郭清の意義は不明である。

以上より，4 群リンパ節の中で左下横隔動脈流域の リンパ節は転移を有しても，郭清することにより，良 好な予後が得られるので, 積極的に郭清を加える必要 があると考えている。また同部リンパ節は現在 4 群と して取扱われているが、リンパ流路から考えると 2 群または 3 群に分類されるべきであると考える。

\section{噴門部癌の臨床病理学的検討}

\section{東京厚生年金病院外科}

松本政雄, 町田武久, 山本登司, 今成朋洋, 松村健三, 志田晴彦, 増田幸蔵, 平岩正樹, 金正文, 黒田敏彦, 海野英哉, 山本滋, 坂 佳奈子

対象：1972年 1 月〜 1986 年 12 月までの 15 年間に 当院外科におらて経験した胃癌症例は724例であり，そ のらち上部胃癌 ( C, CE, CM ) は 116 例 (16\%)であっ た。116例中切除例 96 例, 非切除例 20 例であった。切 除した96例につんて検討した。96例中, 食道胃粘膜境 界領域より $2 \mathrm{~cm}$ 以内に中心をるつ， いわゆる噴門部癌 は 50 例 (7\%)であり, その他の上部胃癌 46 例 ( 以後 単に上部胃癌という）と比較検討した。

結果：男女比は, 噴門部癌では $3: 1$, 上部胃癌 1.7 $: 1$ と男性に多く, 年齢は $28 \sim 84$ 歳で噴門部癌は平 均 63.7 歳, 上部胃癌は平均 64.0 歳であった。術式につ らてみると噴門部癌では胃全摘 46 例 (開沜 11 例)，噴 門側胃切除 4 例, 上部胃癌では胃全摘 41 例, 噴門側胃 切除 3 例, 幽門側胃切除 2 例であった。噴門部癌では 37 例 $(74 \%)$, 上部胃癌では 37 例 $(80 \%)$ 飞治瘜切除 がなされた。 stage 別でみると噴門部癌では stageIII, IVが 12 例 (24\%)，17例 (34\%), 上部胃瘦は 9 例

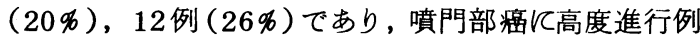
が多かった。組織深達度別飞みて子 ps(+)例は噴 門部旗で 28 例 (56\%)，上部胃癌で 23 例 (50\%) と 噴門部癌に進行例が多かった。n(t)例は噴門部癌で 37 例 $(74 \%)$, 上部胃癌で 23 例 $(50 \%)$ であった。病 理組織型では噴門部輻で pap, tub 1 , tub 2 の分化型が 34 例 (68\%) と, 上部胃癌の 26 例 (56\%) 飞比し分化 型の多い傾向であった。耐術例で累積生存率を比べて みると，その 5 生率は，噴門部癌で $40 \%$ ，上部胃癌で $52.5 \%$ 之噴門部癌の方が予後不良であった。噴門部癌 の stage 別累積生存率を検討してみると，その 5 生率 は stage I で $85 \%$, II $30 \%$, III, IV は 5 生がなく, 3

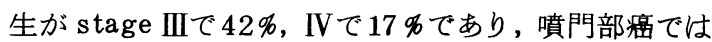
stage III, IV 症例が多いため予後不良であると思われ る。 stage III, IV を規定する因子を検索すると浆膜因

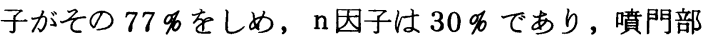
癌には漿膜浸潤陽性例が多的傾向であった。むた食道 浸潤例は, 30 例 $(60 \%)$ にみられ，非浸潤例に比べ予 後不良であった。

結語：噴門部癌は漿膜浸潤が高度で stage が進んだ 症例が多く, 組織学的にみて子 p s ( +), n (十) 例が多か った。病理組織学的には分化型腺癌が多かった。5生 率は $40 \%$ と予後不良であった。 
札㨪医科大学第 1 外科

岡崎 裕, 江端俊彰, 東 毫, 渡部公祥, 秋 野庸一，戸塚守夫，早坂 滉

昭和 52 年 1 月より昭和 61 年 12 月までの 10 年間で当科 で手術した胃癌は674 例である。そのうちC 領域の 胃癌は 105 例であり, 噴門部癌は 42 例であった。 われわれが噴門部癌としたものは，E-C Junction から癌巣の中心までが $2 \mathrm{~cm}$ 以内, あるいは癌巣が $\mathrm{E}-$ C Junction r及び, かつ癌巣中心がC 領域にあるも のである。年令は47才より83才で，男女比は35:7と 男性飞多くみられた。肉眼型では早期癌で I 型 2 例,

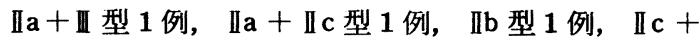
II a 型 1 例であり, 進行癌では Borrmann 1 型 2 例, 2 型 6 例, 3 型 20 例, 4 型 6 例, 5 型 2 例で, Borrmann 3 型が多かった。組織型では pap 6 例, tub 16 例, tub 19 例, por 9 例, sig 1 例, carcinoid 1 例で, 高分化型腺癌が多かった。深達度はm 1 例, sm 5 例, $\mathrm{pm} 7$ 例, ss $\beta 3$ 例, ssr16例, se 7 例, si 2 例, 不

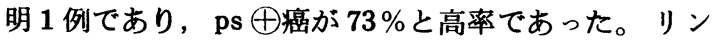

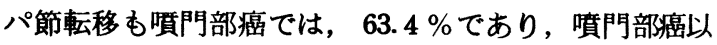
外のC 領域癌 $49.2 \%$ と比較しても高率である。

手術々式であるが，42例中，左開胸・開腹 7 例, 開 腹35例であり, 癌の払がりと深達度によりSo症例に拉 いては, 噴門側切除, $\mathrm{S}_{1}$ 以上の症例では胃全摘を原則 としているが, (3), (4), (5), (6)リンパ節の転移を有する症例 でSoであっても胃全摘を行っている。胃全摘 6 例,

胃全摘十脺脾合併切除 21 例, 噴切 6 例, 噴切十脺脾合 併切除 7 例，食道チュービング 2 例の手術を施行した。 再建術式は, 噴門側切除では食道・胃吻合を, 胃全摘 ではRoux - en -Y 法あるいは空晹間置法により再建 している。食道胃吻合, 食道空腸吻合にはAuto-su ture Model 飞よる器械吻合を行っている。

以上, 昭和 52 年 1 月より昭和 61 年 12 月までの 10 年間 で,われわれが経験した噴門部癌42例につき検討した。 腹部食道に浸潤を伴う噴門部癌では (110), (111) リンパ 節転移例もあり左開胸・開腹手術が望ましく, (3), (4), (5), (6)リンパ節転移のあるものは胃全摘, 勝脾合併切除術 を伴う広範囲リンパ節郭清が適切な手術々式と考えられた。
東京医科歯科大学第 1 外科

竹下公矢, 本田 徹, 斉藤直也, 佐藤康, 砂川正勝, 羽生 丕, 遠藤光夫

胃癌の診断技術の向上にもかかわらず，胃上部癌で はなお進行㾇で発見されることが多い。今回我々は胃 上部に局在する癌のため胃切除を受けた 116 例を，癌 の中心が食道胃境界線の上下おのおの $2 \mathrm{~cm}$ 上内に存在 するいわゆる噴門部癌と，その他の胃上部 ( 局在 ) 癌 の 2 群に分け, 両群の臨床病理学的特徵ならびに外科 治療成績につを検討した。【対象】過去 15 年間に当 科で切除した初発，単発胃癌症例は 975 例あるが，占 居部位が C および CE 領域のものは計 116 例であった。 【成績】(1)内訳は噴門部癌 58 例 ( $\mathrm{C}=\mathrm{E} 10$ 例, C $>\mathrm{E} 34$ 例, C 14例)，その他の胃上部癌(以下胃上部癌) 58 例 ( $\mathrm{C}>\mathrm{E} 8$ 例, C 50 例)であり，前者 $\mathrm{C} \mathrm{CE}$ 癌の占め る頻度が $76 \%$ と高かった $(p<0.05) 。$ (2)手術時年令, 性別, 組織型分布で両群間に差を認めなかった。(3)瘦 单の周在性では噴門部癌で小彎の占める頻度が59\% と 有意に高かった（胃上部癌 36\%)。(4) 肉眼分類別では 噴門部癌で 0 型 (早期癌) が 12 例 (21\%) と胃上部癌 の26例 (45\%) より著しく少なかった $(\mathrm{p}<0.05)$ 。(5)癌 の最大径では噴門部癌で 5〜 $10 \mathrm{~cm}$ ののが $62 \%$ 占め, 胃上部癌より，より大をいものの出現頻度が高かった ( $\mathrm{p}<0.05)$ 。(6)手術術式でみると両群ともに胃全摘が 7 割以上の症例に行われ, 膵, 脾などの合併切除率に も差を認めなかった。一方, 到達経路では開沜を併用 する頻度が噴門部癗で 23 例 (40\%) と胃上部癌の 7 例 (12\%)上り有意に高加た。(7) P,H，n因子の出現 頻度につんては両群間に差を認めないが, 深達度では 胃上部癌で $\mathrm{m}, \mathrm{sm}$ 頻度があわせて $45 \%$ と高く, 噴門 部瘦では ss のものが数多く $(40 \%)$ を占めた $(\mathrm{p}<0.05)$ しかし組織学的進行程度 (stage) 凤つんては両群間に統 計学的な差は認められなかった。(8)リンパ節郭清度でみ ても, $\mathrm{R}_{2}$ 以上が両群に共通して70\%以上の症例に行わ れており, 組織学的治癒切除率でも両群間に差を認め なかった。(9非治癒切除に終った原因をみると, 組織学 的 ow(t)の頻度が噴門部癌で 11 例 (19\%) と胃上部癌の 3 例 (5\%)に比へ，有意に高かった。10リンパ節転移率で は両群ともにCよりも CE症例の方が $\mathrm{n}_{1}, \mathrm{n}_{2}, \mathrm{n}_{3}$ すべて の陽性率が高かった。(11治癒切除例 (噴門部癌 37 例, 胃上部癌 48例)の遠隔成績：a）両群の stage, 治癒度 別背固因子に差はないが，早期癌の頻度は噴門部癌で $30 \%$ 之低かった。b) 再発例の再発形式です両群間に著 明な差異はなかった。c) 累積 5生率 (Kaplan-Meier 法）では噴門部癌 $40.0 \%$, 胃上部癌 $69.3 \%$ と有意の差 を認めた $(\mathrm{p}<0.05)$ 。【まとめ】 $\mathrm{C}$ もくは CE 領域 の胃瘦の5ち, んわゆる噴門癌では早期癌の頻度が少 なく, 切除例の口側断端陽性例す多らととが予後を不 良にしてらると考えられた。 


\section{胃悪性腫晅に対する左開胸開腹術式の検討 名古屋第二赤十字病院 外科 \\ 金子哲也，秋田目利，川辺 博，北川喜己 太田章比古, 吉田英人, 名郷直樹, 山下 满}

長野秀樹, 木元正利, 岩本末治, 牟礼 勉, 清水裕英 瀬尾泰雄, 延藤 浩, 山本康久, 佐野開三

いわゆる高位胃癌に対する手術々式の選択には未だ 異論がある。教室では従来噴門㑡胃切除の適応をやや 拡大して行っており，また可及的に食道噴門部を温存 することを目的として, 90\%以上の超広範囲幽門㑡覀 全摘を行い, 症例によってはoralis totalisで再建す ることに努めている。今回, 教室例から分節胃切除 1 例を除く胃全摘 83 例，噴門㑡胃切除 25 例，亜全摘 14 例の計 122 例の高位胃癌切除例を対象にretrospective に解析を加え，術式の選択について検討した。

術式の選択には術中の進行度判定がよりどころとな るが, このうち壁染達度の肉眼判定と組織判定の一致 率は噴切で92\%, 垔全摘で86\%であったが，全摘では $55 \%$ と低く，過大判定が35\%，過小判定が10\%見られ やや甘くなっている傾向にあった。噴切と垔全摘には 過小判定はみられなかった。

リンパ節転移に対する術中の判定を検討すると,一 致率は低下して50-60\%となり過小判定が22\%, 12\%， 14\%含まれ反省させられる。

病変の大きさとリンパ節転移の有無を見ると, $20 \mathrm{~mm}$ 以下の例にはリンパ節転移はなく，教室例全例の検討

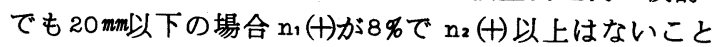
から, 病変の大きさも考慮する必要があるといえる。

切除断端の癌漫潤の判定では全摘例で ow (十)例が 10 例有り,うち7例は肉眼判定 $(-)$ としており,また噴 門㑡胃切除で肉眼判定( ( 例で ow (十)および ow aw とも に(十)を几例ずつ, 垔全摘でow (十)も几例認められた。 断端 $(+)$ となった例の肉眼的距離は10から $14 \mathrm{~mm}$ 平均 11 $m m$ で，(十)例は平均 $23.8 m m$ であり，断端までの距離は 最低 $15 \mathrm{~mm}$ は必要と言える。

各術式の機能的子後について検討すると, 術後早期 には前胸部の閉塞感は全摘群，噴切群ともに約半数に みられ, 噴切群でもやや強い傾向にあった。逆流症状 も噴切群で強く, 亜全摘群では口例もみられなかった。

術後後期でも同様の傾向があり, 噴切群はやや不良 で特に逆流症状は增強したまま残存するものが多く 3 分のエが強い症状を訴えているが㩊全摘群には愁訴が みられなかった。

術後の掫食状況に差がないこと，および根治性の点 から高位の限局性病変といえども胃全摘の選択が第一 であり，噴門側胃切除の選択には特に厳重な考㢝が必 要と考えられた。

さらに再建術式や自動吻合器と手繾い縫合の比較に ついても検討を加え報告する。

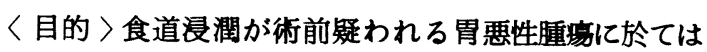
口㑡食道を十分切除する必要があろ。当院では原則的 に上腹部正中切開にて開腹し，切除可能と判断したの ち第 7 肋間開胸を付加していろ。この術式を行なった 症例につき臨床的検討を行なった。

〈対象及び方法〉昭和 57 年 8 月より昭和 62 年 8 月まで の 5 年間に施行された左開胸開腹切開により食道胃 切除が施行された症例は17例である。内分けは胃癌10 例, 胃平滑筋肉腫 1 例, 食道癌 1 例, 横隔膜ヘルニア 2 例, 食道静脈瘤 2 例, 外傷 1 例である。乙の内, 胃 要性腫场に対して施行された11例につき検討した。 〈結果〉同期間中に施行された胃悪性腫蜮に対して施 行された胃切除術は 242 例であり, 胃全摘術は62例で あろ。このうち左開胸開腹切開が施行されたものは11 例であろ。年令は 35 才 77才, 平均 54.7 才, 男性 5 例 女性 6 例であろ。胃癌10例，胃平滑筋肉腫 1 例である。 術式は逆行性左開胸開腹連続切開下部食道胃全摘膵尾 脾合併切除 7 例, 逆行性左開胸開腹連続切開下部食道胃 全摘 3 例, 左開胸開腹連続斜切開によろ下部食道胃全 摘膆尾脾 1 例である。再建は全例 Simple Roux-en Y 法で行なった。

開胸は第 6 又は第 7 肋間で行ない, 横隔膜切開は, 孤状に肋骨弯曲に沿った切開 1 例の他は心学氻ら 1 $1.5 \mathrm{~cm}$ 離れ食道裂孔に向かい切開した。食道裂孔まで 開いたものは 2 例である。縫合不全は 3 例に生じたが 全例保存的治療で治瘁した。切除食道は生体内で $3 \mathrm{~cm}$ 〜 $10 \mathrm{~cm}$ であり, 平均 $5.6 \mathrm{~cm}$ であった。根治手術 10 例, 非根治手術 1 例であろ。術死は 0 である。全例 ow (一) であろ。胃癌に於ては $\mathrm{CME}_{\mathrm{a}} 5$ 例, $\mathrm{CE}_{\mathrm{a}} 2$ 例, $\mathrm{CE}_{\mathrm{a}}$ $\mathrm{E}_{\mathrm{i}} 1$ 例, CMA 1 例, C 1 例であった。予後は 3 例が 存中である。

\section{〈結論〉}

(1) この術式で生体内で10 cm までの食道切除は可能と考 えられ, 食道浸潤の認められろ症例に対し有用であ る。

(2)横隔膜切開は，心高に沿い行なっても横隔神経胸 骨枝を切除するのみで術後特に合併症は認められな かった。

(3)高令者に対しても比較的安全な方法と思われる。 6 ケ月〜 1 年 11 ケ月で死亡, 8 例が10ケ月〜 5 年で生 
354

下部食道浸潤噴門部癌に対する手術術式

の検討

信州大学医学部第 2 外科

○高橋千治, 安達 亘, 梶川昌二, 堀米直人

袖山治嗣, 安本英雄, 黒田孝井, 飯田太

下部食道に漫潤した噴門部癌に対する手術治療にお らては, んかス OW(Hを防ぎ, 縦隔内郭清を確実に行 ならかが問題である。我々は教室における下部食道漫 潤噴門部癌に対する手術術式につんて検討した。

[方法]対象は, 昭和57年より昭和62年までに教室で 手術を施行した下部食道浸闰噴門部癌44例である。乙 れらの症例を，昭和57年より昭和 61 年までの前期 39 例， 手術術式を変更した昭和62年以降の後期 5 例に分け, 検討した。前期の手術術式の適応基準は，ECJ に噴 門部癌の浸潤が及んでいない場合には, 胃全摘, 膵脾 合併切除，ECJV浸閏が及んでいる場合には，食道裂 孔より剣状实起部をでの横隔膜切開による下部食道切 除, 胃全摘, 膵脾合併切除, ECJを越えて下部食道に 漫潤が及んでいる場合には, 胸骨縦切開十横隔膜切開 飞上る下部食道切除, 胃全摘, 膆脾合併切除を施行す るとととした。全例, Roux $-Y$ 再建し, EEAを使用し た。後期は， ECJを越えて下部食道に $5 \mathrm{~cm}$ をで浸潤し ている場合には, 横隔膜切開による下部食道切除, 胃 全摘, 脺脾合併切除, $5 \mathrm{~cm}$ 以上漫潤している場合, ま た術中迅速猃断にてOW(H) と判定された場合には, 開 胸による下部食道切除を施行するとととした。再建は 前期と同様である。

[結果]前期における横隔膜切開施行例 (横切群) は 13例, 胸骨縦切開施行例（胸切群）は26例であった。 胸切群の食道浸潤は最長 $5 \mathrm{~cm}$, 平均 $1.9 \mathrm{~cm}$ であった。 術中での下部食道剥離距離は, 横切群 $8.0 \mathrm{~cm}$, 胸切群 $10.3 \mathrm{~cm}$ であり, 下部食道切除距離は横切群 $5.6 \mathrm{~cm}$, 胸 切群 $7.4 \mathrm{~cm}$ と, 胸切群におらてょり長い食道切除が可 能であった。また全例とも OW(-)であった。しかし， 摘出リンパ節数は, 横切群 1.5 個, 綐切群 1.4 個と同 じであり，術後生存期間にも差は認められなかった。 後期における横切群は 4 例, 胸切群は 1 例である。横 切群の食道漫潤は, 最長 $6.5 \mathrm{~cm}$, 平均 $5.1 \mathrm{~cm}$ で, 下部 食道切除範囲は横切群 $7 \mathrm{~cm}$, 縦切群 $8 \mathrm{~cm}$ であった。摘 出リンパ節数は, 横切群 3.5 個, 縦切群 2 個之ほ添同 数であった。をた全例 $\mathrm{OW}(-)$ であった。前期の胸切群 と後期の横切群を比較すると, 食道切除範囲, 郭清り ンパ節数とも差は認められず, 横隔膜切開の有用性を 認めた。

[結論]横隔膜切開は, 胸骨綎切開による手術と同等 の下部食道切除, 下縦隔リンパ節郭清が可能である。

\section{最近 15 年間の胃癌に対する}

胃全摘術施行例の検討

\section{名古屋市立大学第 2 外科}

片岡 誠, 林 聰一, 藤井 康, 榊原堅式, 橋本隆彦, 高木 格, 辻 秀樹, 谷脇 聰,

桑原義之, 点山泰進, 正岡 昭,

胃癌手術における胃全摘術の適応は癌の占拠部位, 進行度, 癌の性状, 患者の年令, 全身状態, 術後患者 の管理体制, 術者の経豎, 術中の判断, 術者の手術適 応に対する考え方の差等が影響し, 各施設において微 妙な違いを生じているものと考えられる。我々の教室 における胃全摘術の適応も少しづつ変化を来たしてい 万。今回昭和 48 年以降 15 年間の胃全摘術症例を検 討する目的で, 昭和 48 年から 52 年を前期, 昭和 53 年から 57 年を中期, 昭和 58 年から 62 年 7 月を後 期と三期に分けて比較し，乙の間の胃全摘術適応症例 の変化について考察を加えた。

前期の胃癌全切除例は男性 100 例, 女性 53 例, 計 153 例で, うち全摘例は男性 23 例 $(23.0 \%)$, 女性 12 例 $(22.6 \%)$, 計 35 例 $(22.9 \%)$ であるのに対し，中期では胃 癌全切除例男性 110 例, 女性 61例で, うち全摘例は男 性 45例 (40.9\%), 女性 21 例 (34.4\%), 計 66 例 (38.6\%) であり, 後期では胃癌全切除例, 男性 154 例, 女性 81 例で，うち全摘例は男性 54例 $(35.1 \%)$ ，女性 32 例

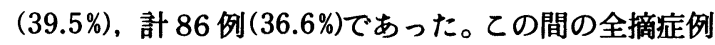
の年令を比較すると，前期では男性 52.4 才，女性 46.1 才, 平均 50.2 才であったのに対し，中期では男性 55.9 才, 女性 52.8 才, 平均 54.9 才, 後期では男性 52.8 才, 女性 55.3 才, 平均 53.7 才で, 前期に較べ, 中, 後期で はわずかに高令化が見られた。全摘例の最高令者は 80 才, 最若年者は 22 才であったが，70才以上の占め万割 合は前期で 3 例 $8.6 \%$, 中期で 11 例 $16.7 \%$, 後期 13 例 $15.1 \%$ と中, 後期で増加していた。中, 後期に胃全摘 例が増加した原因として，(1)高令者例の增加，(2)非治 瘾切除手術に対する適応, (3)根治を目的として切除範 囲の拡大, が挙げられる。近年手術法, 術前, 術後管 理の進歩により, 高令者の適応例が増加し, 非治痹切 除となる症例に対しても胃全摘術に意義を求め, 切除 範囲を抎げるてとで根治性を得ようとする積局的態度 を反映したものと思われる。当教室では昭和 55 年 11 月より器械吻合の使用, てれと前後して中心静脈栄養 によろ術前からの栄養管理, 術前の肺機能訓練を行っ ており, 縫合不全, 術後肺合併症の減少が著明となり てれか間接的に手術適応症例を增加させたと思われる。 胃全摘術は合併症の少ない容易に行なえる手術とな ったが, 術後の栄養状態を長期的に見ると決して良い とは云えない。今後再建術式の改善により，胃全摘術 の施行をより価值あるものにしたいと考える。 
356

胃全摘 (EEA使用例) 術後合併症一とく に梿合不全一の原因, 及び治療についての検討

北里大学消化器疾患治療センター外科 北里大学外科

嶋尾 向, 三重野寛喜, 榊原 蚉, 東 博, 菊地史郎, 山尾哲彦, 渥美純夫, 高橋俊毅, 比企能樹, 阿曽弘一

胃全摘術にEEAが使用されるようになって，手術時 間が短縮され，合併症は少なくなってきている。しか し例数は少なくなったが，なお梿合不全などの問題は 起こってきており，治療に困難を感じることも事実て ある。今回我々は， EEA使用例について，合併症とく に䋖合不全に就いての発生原因とその治療について検 討を加えた。

昭和 46 年か 5 昭和 62 年 8 月までの当大学における胃 癌手術例は 1592 例で，そのうち胃全摘例は 311 例であ る。EEAは 95例に使用し, 35 例に術後なんらかの合併 症をみた。縫合不全は 12 例 $12.6 \%$ にみられ，以下肝機 能障害 6 例, 膵液瘦 6 例, 肺炎 2 例, 胸水眝留 2 例, 腹腔内出血 1 例, 腹腔内膿瘍 1 例, 急性胆宾炎 1 例, 吻合部狭窄 1 例, 逆流性食道炎 1 例, 脳梗塞 1 例であ った。

縫合不全 12 例について, 術前状態および合併疾患と の関係の有無を検討すると, 耐糖能異常 6 例, 心電図 異常 4 例, 堅機能障害 4 例, 負血 3 例, 呼吸障害 3 例, 低栄養 1 例であり， 2 項目以上の異常を認めるものは 7 例に及んだが, 非縫合不全例での検討を比較すると， 明らかな原因となるものは指摘できなかった。

手術時間, 再建術式, 吻合様式 (端側, 端々), 術 中の血圧低下などのトラブルについての検討でも，明 らかな結論は得られなかった。

テクニカルな観点か $5 \mathrm{EEA}$ 使用時期を前期, 後期に わけて検討すると, 前期は 40 例中 8 例 $20 \%$, 後期は 53 例中 4 例 $7.5 \%$ ，後期において明らかな改善が認めら れた。

以上の検討により，縫合不全の発生原因は，患者側 の要因よりは，直接のEEAに対する“慣れ"が最も大 きな問題であると考えられた。

治療に関しては,ドレナージを要したものは 1 例の みで, 他は中心静脈栄養等で保存的に治瘾した。 ドレナージを要した 1 例は，吻合部は全周性に完全に 離解しており，治療にもかかわらず死亡した。実際の EEA使用上のテクニカルな問題点について述べるとと もに,この症例の報告も合せて行いたい。
胃癌全摘術後の食道空腸吻合における 器械吻合と手絴い吻合の比較

\section{東京医科歯科大学第 1 外科}

羽生 丕, 本田 徹, 斉藤直也, 佐藤 康, 竹下公矢, 砂川正勝, 遠藤光夫

われわれは胃癌全摘術後の再建に際して1982年末よ クEEAによる器械吻合を導入し, 以後その使用頻度は 年々增加している。今回は手術成樍, 術後合併症など の面から器械吻合と手梿い伆合の成頛を比較し，その 有用性を検討した。

【対象】1978年1月より1986年12月までに胃全摘を 行った胃癌患者は239例である。このうち94例にEEA による器械吻合が行われ (以下EEA群 )，また145 例 に手梿い吻合が行われた（以下手槰い群）。239の手 術は 50 人の異なる術者によって行われた。術者の経験 年数別の頻度は $5-9$ 年 $44 \%, 10-14$ 年 $26 \%, 15-$ 19 年 $8 \% ， 20$ 年以上 $22 \%$ でっだ。EEA群の再建法 はRoux-Y法74例, 空腸間置19例, Double tract 法 1例であり，使用サイズは $25 m m 50$ 例， $28 m \pi 41$ 例, 31 $m m 3$ 例であった。

【成績】1. 両群の背景因子をみると，1 ) 患者側 の因子ではEEA群の方が平均年龄が高いが（60藏対 56 歳, $\mathrm{p}<0.01)$, 男女比には差飞認めない。2 術者 の経験年数（10年末満の者の頻度）に差を認めない。 3 )癌の組織学的 stage ではEEA群に stage Iが多い が $(40 \%$ 対 $21 \%, \mathrm{p}<0.01)$, 食道浸潤（肉眼的）の頻 度には差を認めなかった。４）手術術式では開胸の頻 度, R-number, 合併切除の頻度, 手術の治窑度には 差を認めないが，再建術式ではEEA群にRoux-Y法が 多かった $(79 \%$ 対 $59 \% ， \mathrm{p}<0.01)$ 。 2. 手術時間は E E A 群が有意に短かかった $(288 \pm 60$ 分対 306 \pm 75 分, $\mathrm{p}<0.05$ )。 3 . 新鮮標本上の切除食道の 長さはEEA群 $19 \pm 17 \mathrm{~mm}$, 手䋖い群 $14 \pm 14 \mathrm{~mm}$ で差を認めた $(\mathrm{p}<0.01)$ 。 4 . 食道空腸吻合部 の縫合不全の頻度は E E A 群 $7 \%$, 手縫い群 $14 \%$ で, 有意差は認めないものの前者に低頻度であった。EEA 群で縫合不全を認めた 7 例中 3 例では, 縫合不全は食 道空腸吻合部そのものではなく，食道と端側吻合した 空腸の断端に発生したものと推測された。 $5 . \quad$ EEA群 の 1 例 $(1 \%)$ に吻合部狭窄を認めたが, 空腸断端の 縫い込みが直接原因と考えられた。6 EEA使用時の トラブルは 9 例 (10件) あり, EEA 挿入時の食道裂創 5 例 ( $28 m m 3$ 例, $25 m m 2$ 例 ), 空腸裂創 2 例, 空腸後 壁のまくれ込み 2 例 , ステイプル咬合不全1例で，いずれ も再度の施行もしくは手縫いに代えてことなきを得ている。

【まとめ】胃全摘後の食道空腸吻合に器械吻合を取 り入れた結果, 手術時間は減少し, 释合不全も少なく なった。本法は要所要所を注意して行えば, 安全で有 用な吻合方法と考えられた。 